\title{
DOES ONE TEST FIT ALL? THE EFFECTS OF STATE-MANDATED ASSESSMENTS ON STUDENTS WITH SPECIAL NEEDS
}

\author{
A Dissertation \\ Presented to \\ the Faculty of the Graduate School \\ at the University of Missouri-Columbia \\ In Partial Fulfillment \\ Of the Requirements for the Degree \\ Doctor of Education \\ by: \\ Teresa D. Nash \\ Dr. Cynthia MacGregor, Dissertation Supervisor \\ July, 2017
}


The undersigned, appointed by the dean of the Graduate School, have examined the dissertation entitled

\section{DOES ONE TEST FIT ALL? THE EFFECTS OF STATE-MANDATED ASSESSMENTS ON STUDENTS WITH SPECIAL NEEDS}

presented by Teresa Nash, a candidate for the degree of doctor of education, and herby certify that, in their opinion, it is worthy of acceptance.

Dr. Cynthia MacGregor

Dr. Kim Finch

Dr. Tamara Arthaud

Dr. T. C. Wall 


\section{DEDICATION}

I dedicate my dissertation work to my family.

To my husband, Dwayne Nash

You have been my biggest fan throughout my college career and throughout our life together. Thank you for your never-ending support, patience, and encouragement. Thank you for being an amazing husband and father who took care of our girls on the nights I had class. This is not just my accomplishment, but OUR accomplishment because I could not have done this without you! I love you!

To my parents, Jack and Barbara Breshears

Thank you for always encouraging and supporting me in everything I do! Your work ethic and love for family have always been inspirational to me! Thank you for being excellent role models and always believing in me! I thank God for giving me such wonderful parents! I love you!

To our daughters, Alysa Barcus and Aymee Nelson

I hope that I have inspired you to set high goals for yourself and to not stop until you reach those goals! I am very proud of the successful, independent women that you have become! Keep dreaming and setting high goals for yourself! Your dad and I will always be here to cheer you on! We love you!

To our son-in-laws, Tim Barcus and James Nelson

Thank you for always supporting our family, especially your wife. Thank you for encouraging and supporting her through her college career and helping to raise your family. We love you!

To our grandchildren, Owyn Barcus, Ebanee Nelson, Gage Nelson, and Olyvia Barcus Thank you for understanding when I had homework! :- I want you to always dream big and never stop dreaming! Your futures are so bright! The world is at your fingertips and you can do whatever you want to accomplish! I hope that you continue the tradition of going to college that your mom and I have set before you! Poppy and I along with your parents will be your biggest fans! We love you very, very much! XOXOXO 


\section{ACKNOWLEDGEMENTS}

I would like to thank the members of my doctoral committee - Dr. Cynthia MacGregor, Dr. Kim Finch, Dr. Tamara Arthaud, and Dr. T. C. Wall - for their time, patience, support, expertise, and feedback through my doctoral research and dissertation. I would like to thank my fellow doctoral students at MU Educational Leadership and Policy Analysis (ELPA) Cohort 9 for their continuing encouragement and feedback. I would like to thank the staff at MU in the ELPA program who have kept me organized in the doctorate program. Last, but certainly not least, I would like to thank the participants in my study for having the courage to share their perceptions regarding the assessment of students with special needs. 


\section{TABLE OF CONTENTS}

Acknowledgements $\quad$ ii

List of Tables $\quad \mathrm{V}$

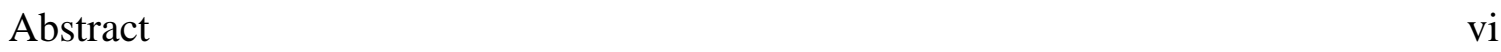

Chapter

1.

$\begin{array}{ll}\text { Introduction to Dissertation } & 1\end{array}$

2.

Leadership and Organizational Context for Study 25

3.

Scholarly Review for the Study $\quad 44$

4.

Executive Summary and Practitioner Report 62

5.

$\begin{array}{ll}\text { Journal Article } & 95\end{array}$

6.

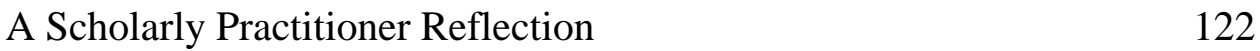

$\begin{array}{ll}\text { References } & 126\end{array}$

Appendix

A.

One Test Fits All - Student Survey

B.

C. 
D.

Informed Consent for Participants in Research Activities Form

E.

Survey Proctor Confidentiality/Protocol/Privacy Agreement

F.

Student Assent Form

G.

Recruitment Scripts

H. 


\section{List of Tables}

Table

1.

Summary of Design of Study

12

2.

Summary of Design of Study

71

3.

One Sample $t$-Test Between Students With IEP and Non-IEP at the State and Local Levels of 2013-2016 English II Performance

77

4.

One Sample $t$-Test Between Students With IEP and Non-IEP at the State and Local Levels of 2013-2016 Algebra I Performance 77

5.

Does One Test Fit All? Student Survey Statements and Responses 79 
Does One Test Fit All?

The Effects of State-Mandated Assessments on Students With Special Needs

Teresa D. Nash

Dr. Cynthia MacGregor, Dissertation Supervisor

Abstract

This mixed methods study examined the effects of requiring students with special needs to take the same assessment as their same-aged peers. A significant difference in student performance on End-of-Course (EOC) exams was found at the state and local level when comparing students with special needs to students without special needs. Students with special needs expressed concerns with not performing well on EOCs, fear of not knowing or remembering concepts assessed, and not being smart enough to go on to college. Student self-esteem, classroom modifications, and assessment procedures of students with special needs were concerning to special educators. By acknowledging that each student performs at different levels, assessing students according to each student's level of performance, and allowing students to experience success, the educational system will be leaving no child behind. 
SECTION ONE:

INTRODUCTION TO DISSERTATION 
Does one test fit all? School districts across the nation are held to accountability standards based on state-mandated assessments. As part of the Missouri School Improvement Program (MSIP 5), the intention of administering state-mandated assessments is to hold public schools accountable for student progress toward the Missouri Learning Standards (Department of Elementary and Secondary Education, 2015). The No Child Left Behind Act of 2001 reinforced the necessity for all students to take state assessments, including students with special needs, and created a universal system of accountability for public schools (Malmgren, McLaughlin, \& Nolet, 2005). However, when creating and modifying policies that mandate all students take state assessments, are we, as a society, assisting or further marginalizing students with special needs?

State and federal governments develop educational policy regarding assessment procedures (Cohen \& Moffitt, 2011). These assessment policies are made by government officials which leave little or no room for autonomy within local education agencies and who often do not understand the educational environment enough to realize the impact of their policies (Omerod, 2007). This top-down approach (Bolman \& Deal, 2008) of developing policies without considering implications to all students could have a detrimental impact on specific subgroups, including students with special needs.

Government officials at both the state and federal level have developed numerous policies in an attempt to hold schools more accountable for increasing student achievement for all students. The Rehabilitation Act of 1973 prohibited discrimination on the basis of disability in programs that received federal funding. The Outstanding Schools Act of 1993 (Missouri Governor's Office, 1993) established new statewide 
performance standards, held public schools more accountable for student performance, and attempted to increase equity in Missouri public schools by adjusting the funding formula. The No Child Left Behind Act of 2001 required states to increase student achievement by having all students perform at "proficient" levels on state assessments by the 2013-2014 school year (Klein, 2015). According to that criteria, about $82 \%$ of schools across the United States and $81.9 \%$ of Missouri public schools would have been labeled as failing in the 2010-2011 school year (McNeil, 2011). More recently, the Missouri Department of Elementary and Secondary Education (DESE) developed Missouri School Improvement Program (MSIP 5) requirements. According to DESE (2015), the Missouri Assessment Program (MAP) was designed to monitor student performance on skills and knowledge based Missouri Learning Standards (MLS). Additionally, DESE launched "Top 10 by 20", an improvement initiative that aims for Missouri to be among the top ten ranking states in the United States. This program analyzes the following criteria: (a) the percentage of students scoring at or above the proficient level on the National Assessment of Educational Progress (NAEP); (b) the percentage of students will increase each year to meet the "on track" MSIP targets for all students; and (c) the percentage of students scoring below basic on state assessment will decrease (DESE, 2016b). At the federal level, President Obama enacted the Every Student Succeeds Act (ESSA) which also monitors student performance on state assessments, sets performance targets, and holds schools accountable for their performance (U.S. Department of Education, 2016a). Data from these assessments provide information at the student, class, school, district, and state levels, as well as, identify individual strengths and weaknesses. In order to meet the accountability 
standards of ESSA, students in Missouri are required to take four End-of-Course exams (EOCs) in Algebra I, Biology, English II, and Government prior to graduation. Additional EOCs in Algebra II, Geometry, English I, American History, and Physical Science may be given at the discretion of the local school district. Students with severe cognitive impairments, English Language Learners (ELL), foreign exchange students, homeschool students, or students attending private schools may be exempt from EOC exams. For this small percentage of the student population, an alternative assessment may be given. Nevertheless, students with special needs who do not qualify for an alternative assessment are still expected to perform at the same level of their peers, regardless of their ability levels.

\section{Statement of the Problem}

Not all students perform at the same level nor do they progress academically at the same rate. Therefore, why is it a requirement that we give all students the same assessment and expect every student to perform at proficient or advanced levels? Applying a statistical measurement in which students are classified by performance using single cut scores may advantage or disadvantage particular subgroups (Wyse, Dean, \& Viger, 2013). "Principles of quality assessment indicate that a variety of assessment activities should be undertaken to inform high stakes assessments" (Cumming \& Dickson, 2007, p. 208). Although many school districts assess student progress on multiple benchmark assessments each year, state and national assessments are assessed on a single end-of-course assessment. "Schools and in some instances students are held accountable for achieving specified levels of performance” (McLaughlin, Embler, Hernandez, \& Caron, 2005, p. 32). 
Policy makers are challenged to ensure that state assessments measure student performance and allow all students to demonstrate what they have learned (Meyen, Poggio, Seok, \& Smith, 2006). According to Cumming and Dickson (2007), “advantage or disadvantage occurs when standard assessment conditions and administration prevent students with a special learning need or disability from being able to demonstrate their learning achievement, where students without such needs or disabilities will not be so hampered" (p. 202). Depending on individual needs of students, testing accommodations may be determined by a student's Individualized Education Plan team to assist the student in communicating concepts learned to off-set skill deficits (Kettler, 2012). Although testing accommodations may be granted, these adjustments do not always assist the student in communicating what is known, especially if daily classroom accommodations do not mirror accommodation options for a specific test. When this occurs, students may become confused and at a loss of how to approach the assessment. This could affect how the student performs on an assessment and overall accountability scores for the district.

When accountability standards are not met, the focus is on the school district, not how the assessment affects the students. Currently, there is a limited amount of studies on educational and assessment equity within public schools. Most studies focus on student performance and how different variables both internally and externally within public schools affect student performance on assessments. Very few studies focus on perceptions of students and educators regarding the impact that state-mandated assessment policies have on students with special needs. 


\section{Purpose of the Study}

The purpose of this study will be to analyze the perceptions of students with special needs and educators of students with special needs regarding the requirement that

all students who do not qualify for an alternative assessment take the same assessment at the same grade level, regardless of current level of performance. Students with various needs who are currently not performing at grade level must take the same assessment as their same-aged peers. The focus of this study will be on the perceptions of students and teachers and how the continuous basic and below basic achievement levels have affected students' self-esteem and outlook for future goals. For the purpose of this study, participants will be students with special needs who have been identified through academic and cognitive testing to receive an Individualized Education Program (IEP) and are currently provided services as identified by an IEP team (DESE, 2015a). This team may include but is not limited to a special education director, a special education teacher, a regular education teacher, the student's parent/guardian, and the student (DESE, 2015b). Aspects of education equity (Alegre \& Ferrer, 2006; Skiba et al., 2008) assessment equity (Lyons, 2004) and advocacy (Kalyanpur, Harry, \& Skrtic, 2000) will be investigated in this case study.

This mixed-methods study will assist policy makers and educators in understanding the effects that state-mandated assessments have on students with special needs through a case study in a small, rural school district in southwest Missouri. Preexisting data from student performance on Algebra I and English II EOCs will be analyzed to determine effectiveness of testing accommodations on previous EOC assessments. Through personal interviews and surveys, students, and educators will 
reflect on their experiences and express their opinions on the impact of state-mandated assessments for students with disabilities.

\section{Research Questions}

The research questions guiding this study are:

1. Is there a significant difference in the performance of students in the subgroup of IEP compared to the overall student performance on the English II and Algebra I End-of-Course assessment?

2. According to the students with special needs perceptions, what are the positive and negative aspects of requiring students with special needs to take the same state assessments as their same-aged peers?

3. According to the special educators' perceptions, what are the positive and negative aspects of requiring students with special needs to take the same state assessments as their same-aged peers?

\section{Conceptual Theoretical Framework}

This study will focus on the impact of policy implementation through the political framework lens. Policies are statements of intended outcomes by the government or other agents to achieve specific outcomes (McDavid, Huse, \& Hawthorn, 2013). Bolman and Deal (2008) recognized that organizations design policy through "consistent goals set at the apex of authority" (p. 198). From the political perspective, goals and policies emerge from bargaining and negotiation from major interest groups. State and federal agencies along with teacher unions and other interest groups influence policies that are developed. The No Child Left Behind Act of 2002 and the 2004 Individuals With Disabilities Education Improvement Act (IDEA 2004) have emphasized the importance of 
closing the achievement gap between students with special needs and their same-aged peers. Understanding how state-mandated assessments affect students with special needs can be monitored through an impact evaluation (Bennett \& Jessani, 2011). Educational equity, assessment equity, and Maslow's Hierarchy of Needs will be utilized to study impact.

Closing the achievement gap is essential to providing an equitable education for all students. Regardless of personal traits, every student has the right to fair and equal treatment through our political system and educational organizations. Educational equity can be measured in a variety of ways. O'Neill (1976) measured equity in terms of outcomes (e.g., standards-based grading, assessments, etc.) rather than inputs (e.g., instruction, accommodations, etc.). A couple of studies agreed with this concept and later identified outcomes based on horizontal and vertical equity (Berne \& Stiefel, 1984; Stone, 2002). Horizontal equity was interpreted to have equal inputs; whereas, vertical equity assumed that different or unequal inputs attained equal outcomes (Stone, 2002). Students learn differently or learn at varied paces, which may result in the need for unequal treatment. In order to assist students with disabilities in "leveling the playing field" with same-aged peers without disabilities, testing accommodations may be implemented. Testing accommodations are designed to remove barriers presented by a disability in order to provide students with equal access to the same opportunities (Ward, 2006).

Assessment equity is a concern for government officials as well as educators. It is important to ensure that all students are given the same opportunity to exhibit their knowledge without having an advantage or disadvantage over another student. 
According to Cumming and Dickson (2007), "advantage or disadvantage . . occurs when standard assessment conditions and administration prevent students with a special learning need or disability from being able to demonstrate their learning achievement, where students without such needs or disabilities will not be so hampered" (p. 202). In order to get an accurate reading on educational progress, a student should be assessed in a fair and comparable way. Furthermore, if a student continuously receives low scores compared to peers, perceptions of one's self or perception of ability to achieve success may diminish (Scott, Murray, Mertens, \& Dustin, 2001).

The theory of human motivation supported by Maslow's Hierarchy of Needs will be utilized to determine the impact of state-mandated assessments given to students with special needs based upon esteem needs. According to Maslow (1943/2005), most people have a desire for a high-evaluation of themselves in the areas of self-respect, self-esteem, and esteem of others. These needs can be classified into two categories: (a) "the desire for strength, for achievement, for adequacy, for confidence in the face of the world, and for independence and freedom" (Maslow, 1943/2005, p. 171); and, (b) "the desire for reputation or prestige (defining it as respect or esteem from other people), recognition, attention, importance or appreciation" (Maslow, 1943/2005, p. 171).

The U.S. Department of Education and DESE require assessment of all students at various grade levels or end of courses. However, the impact of these assessment policies should be examined to ensure equal access is given to all students and ensure assessment practices are not having a detrimental effect on students with disabilities when compared to same-aged peers. Educational organizations need to adapt policies in order to ensure 
that students' self-esteem, perception of ability to achieve success, and prestige are not diminished for the sake of educational accountability.

\section{Design of the Study}

The design of this case study will follow a convergent parallel mixed methods procedure. According to Creswell (2014), a mixed methods approach collects, analyzes, and interprets both quantitative and qualitative data. Through the synthesis of data, a researcher can gain a more complete understanding of a marginalized group by not only analyzing close-ended (quantitative) data, but also considering open-ended (qualitative) data to gain insights from human resources (Creswell, 2013). Through the convergent parallel mixed methods design, data are collected from both quantitative and qualitative measures, analyzed separately, and then compared to see if the data confirm or disconfirm each other (Creswell, 2014).

\section{Setting}

This study will focus on a small, rural high school in southwest Missouri (450 students or less) in grades 9-12. This high school is located in a high poverty area with a free/reduced lunch percentage steadily reported at approximately $70 \%$ and enrollment has consistently decreased over the past several years (Department of Elementary and Secondary Education, 2015f). Although teaching positions have been absorbed whenever possible, the student to teacher ratio has remained steady at 13:1 (Department of Elementary and Secondary Education, 2015g). Over the past three years, the four-year and five-year graduation rates of students with special needs have been higher than the state average (2013-2015) with the majority of these students entering the workforce in 2015 (Department of Elementary and Secondary Education, 2015e). 


\section{Participants}

Participants will consist of a convenience sample within a single stage sampling procedure of students in grades 9-12 who have been identified with a disability, but did not qualify for an alternative assessment. Data regarding these participants will be collected between the years of 2013 through 2016. Additionally, a special education director and special education teachers will serve as participants. These participants will be purposefully selected from the chosen site through a convenience sample as well. Fink (2013) defined convenience sample as people who are willing to participate. A single stage sampling procedure is utilized when the researcher "has access to names in the population and can sample the people (or other elements) directly" (Creswell, 2014, p. 158). These participants were chosen because of their role as key stakeholders within the setting as well as their expertise and experiences within special education. Each research question will focus on different types of data and will include different participants.

Research question one will focus on pre-existing, quantitative data from EOC scores of students with special needs in grades 9-12 as compared to same-aged peers in Algebra I and English II, as shown in Table 1. This information will be located within a database maintained by DESE and will focus on assessment data from 2013 through 2016.

Research question two will focus on student perceptions regarding taking the same assessment as same-aged peers without special needs. As shown in Table 1, students in grades 9-12 who have special needs will be given a survey through a six-point 


\section{Likert scale and open-ended, short answer questions to analyze their perception of}

positive and negative aspects of this policy requirement.

\section{Table 1}

\section{Summary of Design of Study}

\begin{tabular}{|c|c|c|c|}
\hline Research Question & Participant Sample & Data Collection Tool & Method of Analysis \\
\hline $\begin{array}{l}\text { R1: Is there a } \\
\text { significant difference } \\
\text { in the performance of } \\
\text { student in the subgroup } \\
\text { of IEP compared to the } \\
\text { overall student } \\
\text { performance on the } \\
\text { English II and Algebra } \\
\text { I End-of-Course } \\
\text { assessment? }\end{array}$ & $\begin{array}{l}\text { Students with special } \\
\text { needs' EOC scores in } \\
\text { Algebra I and English } \\
\text { II in assessment years } \\
\text { of } 2013 \text { through } 2016) \\
(N=33)\end{array}$ & $\begin{array}{l}\text { Quantitative data from } \\
\text { pre-existing EOC scores } \\
\text { in the areas of Algebra I } \\
\text { and English II }\end{array}$ & One sample $t$-test \\
\hline $\begin{array}{l}\text { R2: What are the } \\
\text { positive and negative } \\
\text { aspects according to } \\
\text { students' perceptions } \\
\text { when requiring } \\
\text { students with special } \\
\text { needs to take the same } \\
\text { state assessments as } \\
\text { their same-aged peers? }\end{array}$ & $\begin{array}{l}\text { Students in grades } 9-12 \\
\text { in rural high school in } \\
\text { Southwest Missouri } \\
(N=33)\end{array}$ & $\begin{array}{l}\text { Mixed methods data from } \\
\text { on-line survey tool }\end{array}$ & $\begin{array}{l}\text { Quantitative data } \\
\text { collected from 6-point } \\
\text { Likert Scale Survey (see } \\
\text { Appendix A) } \\
\text { Qualitative data collected } \\
\text { from open-ended, short } \\
\text { answer questions. This } \\
\text { data will be analyzed to } \\
\text { identify themes through } \\
\text { an open-coding method } \\
\text { (see Appendix A). }\end{array}$ \\
\hline $\begin{array}{l}\text { R3: What are the } \\
\text { positive and negative } \\
\text { according to special } \\
\text { educator's perceptions } \\
\text { when requiring } \\
\text { students with special } \\
\text { needs to take the same } \\
\text { state assessments as } \\
\text { their same-aged peers? }\end{array}$ & $\begin{array}{l}\text { Special Education } \\
\text { Teachers and Special } \\
\text { Education Director of } \\
\text { students in grades 9-12 } \\
\text { in a rural high school } \\
\text { in Southwest Missouri } \\
(N=5)\end{array}$ & $\begin{array}{l}\text { Qualitative data from } \\
\text { Special Education } \\
\text { Teachers' perceptions } \\
\text { will be collected in a } \\
\text { focus group interview } \\
\text { (see Appendix B). } \\
\text { Qualitative data from } \\
\text { Special Education } \\
\text { Director's perception will } \\
\text { be collected in a semi- } \\
\text { structured, face-to-face } \\
\text { interview (see Appendix } \\
\text { C). }\end{array}$ & $\begin{array}{l}\text { All interviews will be } \\
\text { recorded and transcribed } \\
\text { to identify themes } \\
\text { through an open-coding } \\
\text { method. }\end{array}$ \\
\hline
\end{tabular}


Research question three will focus on perceptions of the special education director and special education teachers who serve students in grades 9-12 in a small, rural school district. The special education director will participate in a semi-structured, face-to-face interview. Special education teachers will be interviewed in a focus group discussion, as shown in Table 1.

Each participant, parents, and students will be read a script informing them of the study, the data collection tool used, duration of their participation. Participants will be notified by phone or face-to-face invitation and must sign an informed consent form prior to participation in the study (See Appendix D). The informed consent form will acknowledge the protection of human rights for each participant and will give participants an opportunity to not participate in the study (Creswell, 2014). Parent/guardian consent will be attained for students who are under the age of eighteen (See Appendix H). After parent/guardian consent is obtained, students will be introduced to the study (See Appendix G) and will be given the option of participating (See Appendix F). To avoid exploitation, all active participants who sign the consent form will be offered a copy of the findings within the final research report.

The third party proctor will not be a participant in the study. This person will be a paraprofessional. A confidentiality agreement will be signed by the proctor prior to administering the student survey (See Appendix E).

Interactions will be scheduled in a convenient location and time for the participant and organization so as not to disturb the educational setting (Creswell, 2014). Interviews and surveys will be conducted in the natural setting (own school setting) of the participant. 


\section{Data Collection Tools}

Prior to collecting data, consent forms will be signed. Special education teachers and the special education director will sign the Informed Consent For Participation in Research Activities Form (See Appendix D). The third party proctor will contact parents and read them the Recruitment Script (See Appendix G). Both parents will sign the Parent Permission Form (See Appendix H) prior to students being contacted. Once parent permission is obtained, students will be introduced to the study by the third party proctor. The proctor will read the Recruitment Script to students. If students agree to participate, the student will sign the Student Assent Form (See Appendix F). The link to the students' on-line survey will be written on an index card and given to students.

Qualitative data will be collected through the use of surveys of students with disabilities, an interview with the special education director, and a focus group interview of special education teachers, as shown in Table 1. The purpose of these data collection tools is to gain insights into the perceptions of the participant sample. The interview with the special education director will be conducted face-to-face with a semi-structured interview template. When interviewing special education teachers, a focus group will be used. Krueger and Casey (2009) identified a focus group as a small group of participants who interact in a facilitated interview. Discussions are relaxed and non-threatening with participants' answers building off one another (Krueger \& Casey, 2009). All interviews will be recorded and transcribed in order to identify emerging themes within responses. Interviews and focus group discussions will be conducted during a 20-30 minute timeframe. 
In order to reduce the likelihood of bias, the investigator will not recruit or assent or consent the potential participants. A third party proctor will sign the Survey Proctor Confidentiality/Protocol/Privacy Agreement (See Appendix E) before contacting potential participants. The proctor who is neutral from the project will read the recruitment script to the potential participants, along with the principal investigator's contact information for questions. Written consents, child assent forms, and parental consent forms will be given to participants to take home to read and decide if they which to participate in the study within $48-72$ hours. The third party proctor will collect all signed consents, assent and parental consent forms to give to the principal to ensure that all assent and consents are in order prior to data collection (Creswell, 2014).

The purpose of the survey will be to generalize information from a specific group of participants so inferences can be made regarding the effects of mandated assessments of students with special needs (Creswell, 2014). As shown in Table 1, participating students will be administered an online survey. The online assessment tool will be advantageous in the rapid turnaround of data collection (Creswell, 2014). Due to the sensitive nature of identifying thoughts and feelings of students with disabilities, student surveys will be administered utilizing an online tool. Qualitative data will be assessed within the surveys using open-ended, short answer questions.

With the survey, quantitative data will be collected to address research question one. Quantitative data will be assessed in a six-point Likert scale survey. Additional quantitative data collected will include pre-existing data from End of Course (EOC) assessment scores in the English II EOC and Algebra I EOC, as shown in Table 1. The average student performance will be compared to a set of scores within the IEP subgroup. 


\section{Data Analysis}

Quantitative data within research question one will be analyzed when comparing student performance scores on the English II and Algebra I EOCs through the logic model. The impact of the policy can be analyzed between two groups - students with special needs and students without special needs. McDavid et al. (2013) stated the logic model assists in identifying intended results. Pre-existing data of EOC performance levels in the areas of English II and Algebra I of students with special needs and students without special needs will be collected. Additionally, quantitative data will be analyzed through a one-sample $t$-test that is utilized when "there are two experimental conditions and different participants were assigned to each condition" (Field, 2013). The average student performance will be used as the test value and compared to a set of scores in the subgroup of IEP. The IBM SPSS computerized software program will be utilized to compute these statistics. This data will be used to answer research question one.

Quantitative data through surveys will be analyzed through the use of SurveyMonkey, an on-line survey tool. Responses will be collected through a six-point Likert scale, ranging in responses from strongly disagree to strongly agree. Frequencies and percentages of each response will be recorded and used to clarify findings.

Qualitative data will be collected on the student survey through open-ended questions. Responses were coded to identify common themes. This data will be used to answer research questions two and three.

Qualitative data within research questions two and three will be analyzed through the use of grounded theory. According to Creswell (2014), grounded theory "is a design of inquiry from sociology in which the researcher derives a general, abstract theory of a 
process, action, or interaction grounded in the views of participants" (p. 14). Responses from all participants will be recorded, transcribed, and coded to identify specific themes of responses. Interviews, focus groups responses, and open-ended questions on the survey will be analyzed through an open-coding method. While transcriptions are read and analyzed, the researcher will notate the document with identified themes. The researcher will be open to any possible themes at this point; therefore, this process is referred to as open-coding (Merriam, 2009). Since the amount of data will be immense, the researcher will winnow the data in order to focus on specific themes (Guest, MacQueen, \& Namey, 2012). Creswell (2013) suggested narrowing data down to five to seven themes. Data will be analyzed until saturation occurs. Creswell (2014) identified saturation when data no longer provides new insights. A theme will be identified as occurring in two or more documents, interviews, or discussions.

Validity and reliability will be assessed through triangulation of data and member checking. Triangulation occurs when evidence is confirmed through several resources (Creswell, 2014; McDavid, Huse, \& Hawthorne, 2013). Member checking determines accuracy of findings by conducting a follow-up interview with participants in the study and allowing them the opportunity to comment on findings (Creswell, 2014).

The researcher previously served as a special education teacher for five years, assistant principal for four years, and as building principal for the most recent seven years, all in the setting of the case study. Background knowledge in special education assessment and processes, knowledge in EOC assessments, as well as knowledge of the culture within the community will be advantageous for the researcher. In order to reduce bias, an external auditor will be assigned to the case study. This person will not be 
familiar with the researcher and can provide an objective assessment of the project throughout the case study (Creswell, 2014).

\section{Limitations, Assumptions, and Design Controls}

This study had several limitations. First, because of the small sample size within one school district in southwest Missouri, generalizability was limited. Future research should focus on expansion of demographic variables and geographical locations for stronger generalizations and recommendations.

Secondly, although the researcher has taken several precautions to reduce bias, interpretation of the findings could be shaped by the researcher's background and history. The researcher was raised within the community, attended the public school in grades kindergarten through twelfth grade, and developed a career in the same setting as the participants. Due to the researcher serving as classroom teacher and then as an administrator within the same setting, response bias could occur from students and special education faculty. In order to reduce the likelihood of response bias from students, the third party proctor will not be the researcher or a teacher participant of this study.

Lastly, the research design will utilize a mixed methods study in order to gain insights within the responses from the participants. There are numerous variables that could affect the perceptions of students, parents, and faculty members and not all of them could be addressed or identified. Due to time constraints, it will important to identify the top three to five themes that emerged from the findings. 


\section{Definition of Key Terms}

\section{Policy Analysis Terms}

Policy analysis. Policy analysis is a social and political activity that focuses on governmental action as well as the institutions that implement the policy (Bardach, 2012). The purpose of this study is to analyze the impact of state-mandated assessments on students with special needs. As policy analysis and impact of policy are primary components of this study, an understanding of related terms is critical.

Impact evaluation. According to Bennett and Jessani (2011), an impact evaluation examines the effectiveness of a project or policy by including the "positive and negative, the intended and the unintended at the end of the project cycle" (p. 234). Through the use of mixed-methods design data will be used to determine the impact state-mandated assessments have on students with special needs whether positive or negative.

Education equity. Equity in education consists of opportunities and outcomes in the context where "students participate in educational experiences and the extent to which those experiences enable their academic growth" (Valenzuela, Copeland, Huaqing Qi, \& Park, 2006, p. 425). This study will examine the assessment equity that were given to students with special needs within the regular and special education classroom settings.

Assessment equity. Equity in assessment is essential to analyze the academic achievement of students. Assessment equity refers to the equal or fair opportunities for students to demonstrate their academic learning (Cumming \& Dickson, 2007). Advantage or disadvantage occurs when "assessment requirements inappropriately favour, or are biased towards, specific cultural knowledge" (Cumming \& Dickson, 2007, 
p. 201) or when "standard assessment conditions and administration prevent students with a special learning need or disability from being able to demonstrate their learning achievement, where students without such needs or disabilities will not be so hampered" (Cumming \& Dickson, 2007, p. 202).

\section{Educational Terms}

Students with special needs. DESE (2015b) defines a person with a special need as one who has a physical or mental impairment that substantially limits one or more major life activities, a person who has a history or record of such an impairment, or a person who is perceived by others as having such an impairment. For the purposes of this study, a student with special needs is a person who has been identified through a series of assessments that requires an Individualized Education Program (IEP) within a school setting, but will not include students with severe disabilities who have qualified for an alternative assessment.

Missouri School Improvement Program (MSIP 5). According to the Missouri Department of Elementary and Secondary Education (2015k), the Missouri School Improvement Program (MSIP 5) is responsible for reviewing and accrediting 519 school districts in Missouri. This process is regulated by state law and by the State Board of Education. The goal of MSIP 5 is to prepare every Missouri student for college and career readiness upon completion of graduation requirements (DESE, 2015k).

End-of-course exams (EOC). The Missouri Assessment Program assesses student performance towards the Missouri Learning Standards (DESE, 2015j). As part of this program, End-of-Course (EOC) exams are given once a student has received instruction within a specific area. Mandatory EOCs have changed over the years; 
however, Algebra I, English II, Biology, and Government have been constant assessments. All students are required to take these assessments for accountability purposes, regardless of ability levels, unless a student has been determined by an IEP team that the student is eligible for a MAP-A assessment, English Language Learners (ELL) who have been in the country 12 or fewer months, foreign exchange students, home schooled students, and private school students.

Testing accommodations. Testing accommodations refers to changes in a way that an assessment is administered to a student. "Testing accommodations are intended to offset distortions in test scores caused by a disability without invalidating or changing what the test measures" (Elliot, Braden, \& White, 2001, p. 187). Some of the most common testing accommodations include small group testing, extra time, assistance with reading, assistance with a scribe, and enlarged print of the assessment.

Individualized Education Program (IEP). Once a student has been identified with a disability, an individualized education program is developed by a group who make up an IEP team. This team can include, but is not limited to the student, parent/s, local education agency representative, special education teacher, regular education teacher, person who can interpret evaluation results, transition service representative (if applicable), and others deemed necessary to provide input in developing an education plan for the student. An IEP includes area of disability, services summary, present level of academic achievement and functional performance, special considerations (modifications and accommodations), IEP annual goals, transportation needs, regular education participation, placement considerations and decision (DESE, 2015b). The IEP 
is reviewed annually with progress updates and evaluation results are updated or accepted at least every three years.

MAP-A Assessment. The MAP-A Assessment is an alternative assessment given to students who have been (a) evaluated and found eligible under IDEA, (b) identified with the most significant cognitive disabilities and limited adaptive skills that my be combined with physical or behavioral limitations, (c) identified with the most significant cognitive disability that impacts the student's access to the curriculum and requires specialized instruction, (d) identified with a significant cognitive disability that impacts the student's post-school outcomes, and (e) identified with an inability to participate in regular assessment not due to excessive absences, visual or auditory disabilities, or social, cultural, language or economic differences (DESE, 2013). If the MAP-A is given to more than one percent of the tested population in a specific content area, a district must provide justification for going over the one percent rule.

Student Learning Outcomes. According to Nygaard, Holtham, and Courtney (2009), student learning outcomes refer to desired knowledge that students are expected to know after participating in a particular program or course.

Process/Delivery Outcomes. Process/delivery outcomes refers to the how the program is delivered through instructional strategies and activities (Gordon \& Steele, 2015).

\section{Significance of the Study}

The University of Missouri encourages scholarly communication within books, journals, and electronic forms (Blanken, 2012). The purpose of this study is to gain knowledge of the effects that state-mandated testing has on students with special needs 
who do not qualify for an alternative assessment. Contributions to both scholarship and practice could be developed; however, communication of the findings might be more beneficial in the area of practice.

In the area of scholarship and practice, educational leaders and policy makers could benefit from this study by knowing the effects that state-mandated assessments have on students. What can we do differently to prevent adverse effects of administering the same test to students with different ability levels? How might the educational system test students at each student's ability level so all students may experience success rather than failure? How will this affect a student's self-esteem and encourage the student to look forward to possible college or career choices with optimism rather than a fear of failure?

When all students are tested at their ability level, it can provide valuable information on how to assist students individually to accomplish their postsecondary goals. By focusing on areas needed to prepare individual students for individualized college and career goals, assisting students at the level which they are currently performing, and addressing the needs of each student at their ability level, educators would have a solid base on which to build and address the areas of deficit to make each student successful.

\section{Summary}

This study will examine the effects of requiring students with special needs to take the same assessment as their same-aged peers. Positive and negative aspects along with long-term effects of taking the required state assessment will be examined based on the perceptions of students with special needs and educators of students with needs. 
When students with special needs are required to take the same state assessment as students without special needs and a score of basic or below basic continues to be the result, educators and policy makers are providing a disservice to students with special needs. By acknowledging that each student performs at different levels, assessing students according to each student's level of performance, and allowing students to experience success, the educational system will be leaving no child behind. 


\section{SECTION TWO:}

LEADERSHIP AND ORGANIZATIONAL CONTEXT FOR STUDY 


\section{Introduction}

American society is made up of groups of people who have incompatible needs and interests and are "locked in a perpetual struggle to protect their interests, to dominate other groups, or at least to defend their interests against the encroachment of competitors" (Mitchell, 2011, p. 15). Democracy is created by power balancing which allows citizen groups the opportunity to pursue and protect their own interests (Mitchell, 2011). Political bargaining, negotiation, and the desire for power positions result in building allies. Although their agendas and interests may only partly overlap, these groups form coalitions because they feel they get more accomplished together than alone (Bolman \& Deal, 2008). According to Brown and Cooper (2011), it is important to determine who has influential power, whether its based on position or personality, and who the key actors are within the organization because these are the active participants who can have the power to shape educational policy.

Shaping educational policy and ensuring the impact these policies have an equitable outcome on citizens they affect is a high priority for educational leaders as well as families and local communities (Mitchell, 2011). Equity is a value that is most often neglected because "it logically arises after the policy system has found a qualitative reason to impose on citizens' liberties and after there is enough efficiency in the policy that it can be expected to deliver benefits worth its costs" (Mitchell, 2011, p. 20). Although infrastructures have been in place to help guide federal, state, and local organizations, there continue to be outside forces that influence policies. 


\section{Organizational Analysis}

Beginning with 13 original colonies of the United States and later with the Tenth Amendment of the U.S. Constitution, specific guidelines were established to decentralize the educational system in the United States (U. S. Department of Education, 2005). Throughout history, the educational system has evolved to provide guidelines and governance structures to enhance the educational system in the United States. Governance of the educational system in the United States is divided among three governing entities. At the top of the hierarchy of power is the U.S. Department of Education. Policies and mandates are created at this level and then disseminated to the Department of Elementary and Secondary Education within each state. At that level, more mandates, policies, and/or procedures for governance are established and then bequeathed to the local education agency. Although there are many mandates and policies that are established at the federal and state levels through a top-down approach (Bolman \& Deal, 2008), there is some autonomy at the district level.

\section{U.S. Department of Education}

The original U. S. Department of Education was created in 1867 to collect information on public schools and establish effective school systems across the United States. Although there have been many changes within the Department of Education over the past 140 years, the goal of enhancing the educational system continues to this day. Currently, the U.S. Department of Education administers and coordinates federal assistance to education by executing educational policies and implementing laws created by Congress (U.S. Department of Education, 2010). The U.S. Department of Education is led by the Secretary of Education, a Deputy Secretary, and an Assistant Secretary who 
monitor and manage federal policies, programs, and activities, as well as nine program offices. The four major types of activities of the U.S. Department of Education are (a) establishing policies for fiscal aid by formula, competition, or financial need, (b) collecting data, overseeing research, and disseminating information to Congress and the public, (c) identifying and communicating major issues in education and recommending educational reform, and (d) enforcing statutes prohibiting discrimination and ensuring equal access for every individual (U.S. Department of Education, 2010a). The U.S. Department of Education is only one of the three entities within the educational system across the nation; therefore, Congress wanted to ensure there were state and local education agencies that could have control over specific educational needs and desires within their region. In 1979, Congress established some guidelines and prevented the U.S. Department of Education from (a) development of curricula, (b) establishment of schools or colleges, (c) setting enrollment or graduation requirements, (d) determination of state educational standards, and (e) development of testing criteria to determine if local education agencies are meeting state educational standards (Library of Congress, 2015). These specific needs are addressed by each state and local district with the assistance of public and private organizations within those regions.

Various organizations, including Congress, can be influenced by a variety of competing internal and external stakeholders (Bolman \& Deal, 2008). Although test scores are one of the most driving forces in dissatisfaction in the market of public schools (Harris \& Witte, 2011), parents tend to value academic quality and safety (Armor \& Pesier, 1998). Coalitions represent special interest groups or unions and provide bargaining and negation in order to reach agreements between organizations with the 
same interests (Bolman \& Deal, 2008). Some of these coalitions within the educational field include teacher unions, lobbyists, administration associations, student advocate groups, adult service groups, and many other special interest groups. These influencers can vary depending on interests, hidden agendas, and desired outcomes (McDavid, Huse, \& Hawthorne, 2013).

\section{Missouri Department of Elementary and Secondary Education}

The State of Missouri legislative branch creates public school laws for Missouri and also develops the Code of State Regulations for DESE. Similar to the federal government, the state government is also influenced by a variety of internal and external organizations. Within DESE, the Office of Governmental Affairs utilizes the regulations set forth by the legislature in order to provide counsel to the staff and serve as a liaison to other state and federal agencies (DESE, 2016f).

In 1945, the Missouri Constitution developed the State Board of Education and the office of Commissioner of Education. The vision and mission statement of the Missouri Department of Elementary and Secondary Education (DESE) as well as the duties of the Commissioner of Education have been revised over time. Currently, DESE is missioned "to guarantee the superior preparation and performance of every child in school and in life" (p.1) by ensuring all Missouri students (a) graduate college and career ready, (b) are prepared to enter kindergarten and be successful in school, (c) prepare, develop, and support effective educators, and (d) improve departmental efficiency and operational effectiveness (DESE, 2015d). The Commissioner of Education directs DESE in fulfilling duties prescribed by law as well as elevating standards and efficiency of instruction in Missouri public schools (DESE, 2015c). The State Board of Education 
determines the Commissioner of Education whose duties entail chief of staff, communications, and general counsel and government affairs. The two deputy commissioners which serve under the Commissioner of Education are the Deputy Commissioner of the Division of Learning Services and Deputy Commissioner of the Division of Financial and Administrative Services. The Deputy Commissioner of the Division of Learning Services leads six different offices: (a) Office of Quality Schools, (b) Office of Educator Quality, (c) Office of Special Education, (d) Office of College and Career Readiness, (e) Office of Adult Learning and Rehabilitation Services, and (f) Office of Data System Management. The Deputy Commissioner of the Division of Financial and Administrative Services supervises five different offices: (a) Budget, (b) Financial and Administrative Services, (c) Food and Nutrition Services, (d) Accounting and Procurement, and (e) Human Resources.

In order to address students with special needs, DESE developed the Missouri Special Education Advisory Panel (SEAP) and the State Interagency Coordinating Council (SICC) in order to (a) advise DESE of unmet needs, (b) comment publicly on proposed rules and regulations, (c) advise on developing corrective action plans, (d) develop evaluations and report data, (e) develop and implement policies, and (f) advise on education of students with special needs in adult prisons (DESE, 2016c). This panel membership which serves a three year term includes (a) parents, (b) individuals with disabilities, (c) teachers, (d) representatives of higher education, (e) state and local education officials, (f) administrators of programs for students with special needs, (g) representatives from other state agencies involved in financing and delivery of related services, (h) private and charter school representatives, (i) vocational, community, or 
business organization for transitional services, (j) child welfare agency representative, and (k) state juvenile and adult corrections agency representative (DESE, 2016d). The Commissioner of Education appointed all of these committee members to this panel which has at least four meetings scheduled per calendar year (DESE, 2016e). According to Kotter (1988), an effective leader creates a vision to balance interests of key players and recognizes competing internal and external forces. To assist in building networks and coalitions, key stakeholders must be identified and relationships must be built (Bolman \& Deal, 2008). Policies and procedures have been developed to assist education agencies at the local level through networks and coalitions.

\section{Local Education Agency}

In the early seventeenth and eighteenth centuries, the decentralized nature of the U.S. education system deemed local communities responsible for education. Each community developed and supported its own school based on the priorities, values, and needs within the local community. This practice set a precedent for local and state control over elementary and secondary education. Although there are federal and state guidelines, there continues to be local control over educational policies and procedures within the local education agency.

Currently, local school districts are comprised of a local school board which consists of 5-7 board members within the community. The primary purpose of the board is to (a) develop policies, rules, and procedures for management and administrative actions of the district, (b) hire a superintendent as chief executive officer, (c) evaluate implementation and effectiveness of programs, (d) adopt annual budget, (e) employ professional and support staff, (f) inform public about the school and keep self and staff 
informed of public wishes, $(\mathrm{g})$ establish educational goals and ongoing evaluation of school programs, and (h) act as court of appeals for fairness when board policies are in question (Missouri School Board Association, 2000). Depending on the size of the district, other administrators may be employed, such as assistant superintendents and building-level administration.

Within the special education realm of the organization, each school district is set up differently depending on school size and budget aspects. The participating school district for this study is made up of one special education director, a process coordinator, nine special education teachers (three of which are housed within grades 9-12), and eleven paraprofessionals. The role of the special education director is to supervise the special education department - evaluate special education staff, facilitate special education meetings, and monitor all special education paperwork for state and federal policy compliance. Within this district, however, the special education director also monitors programs for 504 Plans, Homeless, and English Language Learners, as well as, manages administrative duties within the district whenever other administrators are out of the building. The process coordinator assists the special education director in daily duties and also monitors and manages time lines and testing protocols. Special education teachers serve as classroom teachers and case managers for students with special needs, assist in developing Individual Education Programs (IEPs), and monitor classroom modifications and testing accommodations for students on their caseload. Paraprofessionals assist special education teachers within the classroom and assist individual students as needed. 
Local IEP teams are established to ensure that educational plans are designed to meet the needs of individual students. The IEP team usually consists of parents/guardians, the student, local education representative (usually the special education director), special education teacher, regular classroom teacher, individual interpreting instructional implications of evaluation results (usually the process coordinator), and any other individual or outside agency who is invited by one or more members of the team (DESE, 2015). During an IEP meeting, the team discusses the student's present level of academic achievement and functional performance, determines least restrictive environment, discusses progress of IEP goals, sets new IEP goals, and determines classroom modifications, testing accommodations, and transitional services needed. The IEP team meets annually or can meet as often as needed to ensure proper services and progress of the student.

The local education agency, especially in small, rural communities, is influenced by the community, which includes the family structure. In these rural areas, school districts are considered the hub of the community. Although the board of education sets governing policies and procedures, members of the board are elected in order to represent the good of the community. Parents and community members are the major influencers within the community and often serve on various committees. These advisory committees are set up at the local level to get input and buy-in from stakeholders within the community. Through correspondence with stakeholders, it is important for leaders to be "honest, accurate, fair, impartial, competent, highly skilled, and credible in the work we do" (McDavid, Huse, \& Hawthorn, 2013, p. 433). These attributes contribute to authentic leadership. 


\section{Authentic Leadership Within the Political Frame}

As educational leaders, it is imperative to constantly analyze policies that affect the students who will eventually be the people within society. When the outcomes of policies create an environment where there are unfair burdens imposed on some citizens, educational leaders play a prominent role in overcoming inequality of educational opportunities (Mitchell, 2011). By knowing and standing on one's own core values and beliefs, building trusting relationships with others, and acting with passion on one's mission, an authentic leader emerges (George, 2003; Mitchell, 2011; Northouse, 2013). Walumba, Avolio, Gardner, Werensing, and Peterson (2008) identified four components of authentic leadership that could be utilized to shape educational policy: (a) self awareness, (b) internalized moral perspective, (c) balanced power, and (d) relational transparency. An emphasis of these components coupled with the willingness to serve others will enhance one's political power to motivate others and accomplish important changes for the common good to create equitable educational opportunities for all students (Bolman \& Deal, 2008; Kotter, 1982).

\section{Shaping Policy Through Self-Awareness}

Goleman (1996/2011) defined self-awareness as “knowing one’s strengths, weaknesses, drives, values, and impact on others" (p. 3). "Self-awareness includes reflecting on your core values, identity, emotions, motives, and goals, and coming to grips with who you really are at the deepest level" (Northouse, 2013, p. 263). By reflecting upon and knowing one's self realistically, a leader can learn how to deal with their weaknesses in a way that promotes self-confidence and increases the effect that they have on others (Goleman, 1996/2011; Northouse, 2013). Most people do not set 
themselves up for failure, but learn to emphasize their strengths and surround themselves with people who can help them overcome their own weaknesses. When leaders have a strong sense of who they are and what they stand for, a stronger anchor is established for their decisions and actions (Gardner, Avolio, Luthans, May, \& Walumbwa, 2005) and leads to a more authentic leader (Northouse, 2013).

\section{Shaping Policy Through Internalized Moral Perspective}

Internalized moral perspective refers to the how individuals used their moral standards and values to guide their behavior rather than allowing the influence of external pressures (Northouse, 2013). Having a solid base of values tested through outside influencers can result in building leadership principles that are translated into action (George, Sims, McLearn, \& Mayer, 2007/2011). In order to create change or make decisions within organizations, leaders must constructively collaborate, build relationships, and most importantly, rely on their own values and ethical principles (Bolman \& Deal, 2008). This self-regulatory process limits the amount of influence allowed by others while exhibiting authentic leadership where actions are guided by one's own beliefs, morals, and values (George, Sims, McLean, \& Mayer, 2007/2011; Northouse, 2013).

Although an internalized moral perspective is important within a political change agent, it is just as important to keep one's perspective in check in order to eliminate bias and conflict of interest. The American Educational Research Association (AERA, 2011) acknowledged that researchers have a professional responsibility to the communities and societies in which they work. Researchers should strive to advance scientific and scholarly knowledge for the public good (AERA, 2011). 


\section{Shaping Policy Through Balanced Processing}

Balanced processing allows a person to analyze information objectively and explore other's perspectives before making a decision (Northouse, 2013). Leaders should pool knowledge and ideas through various perspectives (Levi, 2014), including opinions from practicing educators and students with disabilities. The process of listening to various perspectives could assist in avoiding favoritism, remaining unbiased, and making decisions, even ideas in which the leader or policy maker may not agree (Northouse, 2013).

The Department of Elementary and Secondary Education (DESE) utilizes various methods to communicate with and listen to numerous stakeholders. Information regarding DESE's activities and programs are communicated through DESE's website. Multiple webinars, administrative memos, and web applications assist in communicating DESE's policies, programs, and activities, while also soliciting feedback from administrators, educators, parents and students, and adults and the community. The Commissioner along with other DESE personnel present and gather information at conferences and professional development seminars.

As a policy maker in a large organization, such as statewide education, it is important to "involve the right people at the right level in the right part of the organization at the right time" (Rogers \& Blenko, 2006/2013, p.111). "Since organizations depend on their environment for resources they need to survive, they are inevitably enmeshed with external constituents whose expectation or demands must be headed" (Bolman \& Deal, 2008, p. 235). In order to make effective and unbiased decisions, policy makers must make decisions based on the organization's best interest 
and free from unconscious or unethical biases by (a) regularly auditing one's decisions, (b) exposing oneself to non-stereotypical environments, and (c) considering all options (Banaji, Bazerman, \& Chugh, 2003/2013).

DESE's Office of Special Education administers state and federal funds to support services, such as outreach programs and consulting services, to assist school personnel and families to meet the needs of children with disabilities (DESE, 2016a). At the local level, these funds are distributed through the annual budget set forth by the superintendent. Having open communication about how these funds are disseminated and how they meet the needs of students with special needs will increase future cooperation when trying to obtain input from stakeholders.

\section{Shaping Policy Through Relational Transparency}

Relational transparency is about "communicating openly and being real in relationships with others" (Northouse, 2013, p. 264). This includes sharing core feelings, motives, and inclinations to others (Kernis, 2003) while showing both the positive and negative aspects of their beliefs or important concepts (Goffee \& Jones, 2000/2011; Northouse, 2013). Change within organizations or political arenas must adapt to the needs of demands by their customers and constituents (Bolman \& Deal, 2008). By being open, honest, and transparent with others, trust is established and can open the door to new possibilities.

Building trust is a process. In order to build trust and establish relational transparency everyone must work together (Levi, 2014). Trust is the confidence that one possesses to encourage others to follow through with their commitments (Thompson, 2004). By allowing stakeholders to be part of shaping policy and sharing their 
experiences, they become powerful anchors in the policy process, rather than impeding forward movement in establishing or modifying policy (Bolman \& Deal, 2008).

Through relational transparency and building trust, it becomes easy to communicate a message to policy makers and influencers. It becomes apparent that one is genuine and approachable (Goffee \& Jones, 2000/2011), which in turn, can lead to a productive relationship and more opportunities to shape policy.

\section{Summary}

Being transparent, open, honest, and approachable creates a trusting relationship with others. Through this relationship, it is easier to get to know people better and learn who influences them, who they influence, and evaluate the power of their influence. Maxwell (2006) stated the more influence you have, the more leadership potential you possess and more ability for others to work with you to achieve your dreams.

\section{Implications for Research in the Practitioner Setting}

Assessing students has been viewed as an accountability measure at the federal and state levels for many years to measure how well students acquire the skills and knowledge taught within public schools. At the federal level, the Scholastic Aptitude Test (SAT) began in 1926 with the American College Testing (ACT) beginning in 1959 (Fletcher, 2009). At the federal level, both tests are still accepted as standardized tests today. With these assessments, the acceptability of colleges and universities depends on one's geographic location. In the Midwest and South, the ACT is more commonly accepted; whereas, the schools on the coasts prefer the SAT (Fletcher, 2009).

At the state level, revisions of the Individuals with Disabilities Act (IDEA '97)

required states to include students with special needs in the accountability systems of the 
state, but includes an alternate assessment to measure the progress of students with mental retardation (Yell \& Katsiyannis, 2010). With the revision of IDEA in 2004 and No Child Left Behind Act, students with special needs were still required to take all state and district-wide assessments, but added a statement requiring any appropriate accommodations that may be necessary to measure academic achievement and functional performance of the student (U.S. Department of Education, 2016b).

State assessments have been referred to by many names: Iowa Test of Basic Skills, Building Essential Skills Test (BEST) beginning in 1979, and now the Missouri Assessment Program (MAP). As the state learning standards have evolved, so have the focus of the assessments. According to DESE (2015j), state assessments are used to diagnose individual strengths and weaknesses of individual students and the overall quality of education in Missouri.

The current assessment is known as the Missouri Assessment Program (MAP), which is utilized in grades three through eight. End-of-Course (EOC) exams are given to grades nine through twelve and assess information at the end of a course rather than grade level. Currently EOCs are given at the end of Algebra I, English II, Government, and Biology. Other EOCs, such as Algebra II, Geometry, English I, American History, and Physical Science are available for districts, but are not required. Required EOCs have varied throughout the years with English I, Geometry, Algebra II, and American History included in the list. State assessments have varied in names throughout the years. Beginning in 2015, Missouri required the ACT to be given to all students at the eleventh grade level along with the required EOCs. 
Students with special needs have had various requirements for state-mandated assessments throughout the years. When the BEST was given in 1979, students with special needs were exempted from the test if the Individualized Education Program (IEP) team decided that it was not in the student's best interest to take the assessment (Ranbom, 1983). Currently, the MAP-Alternate (MAP-A) is given to some students with special needs when it is determined that the MAP or EOC is not appropriate due to the disabilities of the student. According to DESE (2015j), the MAP-A is used to promote enhanced capabilities and integrated life skills and only utilized for the most significant cognitive disabilities when grade level and eligibility criteria have been met.

Furthermore, districts that have more than $1 \%$ of their population utilizing the MAP-A assessment program, must provide a rationale as to why more than $1 \%$ of the population is considered MAP-A.

Students who have special needs, but do not qualify for the MAP-A, are given testing accommodations to assist in assessing the student's acquired skills and knowledge within these content areas. However, based on the assessment, the students may or may not receive the same accommodations they have on a daily basis within the classroom. For instance, in some areas of the EOC, students may not have passages read or on the ACT, extended time is limited to an extra hour and half.

This mixed methods study will focus on the equity of the current state testing policy and how this policy affects students with special needs. Very few current studies consider the impact this practice has on students when assessing students with special needs with the same assessment as their peers who do not have special needs. This study 
will investigate the impact of one assessment given to all students and identify the pros and cons of this assessment practice towards students with special needs.

The best way to inform policy makers of the findings of the study is to inform both the executive and legislative branches of government. Within the executive branch, findings will be shared with the Missouri Department of Elementary and Secondary Education commissioners, assistance commissioners, and directors -- more specifically, Dr. Stacey Preis, Deputy Commissioner of Education; Dixie Grupe, Director in the Office of College and Career Readiness; Stephen Barr, Assistant Commissioner of Special Education; Sarah Potter, Communications Coordinator; and Shaun Bates, Director of Assessment. Within the legislative branch, findings will be shared with committee appointments that are directly tied to education. Specific advocacy groups will be informed, such as Council for Exceptional Children, Missouri Vocational Rehabilitation, Missouri Parent Teacher Association, Missouri School Boards Association, Missouri Association of Secondary School Principals, and Missouri Association of School Administrators.

An overview of the study will be sent to each person or organization. In order to mobilize these individuals or organizations on the findings, a rationale of how these findings will help students and how these findings reflect on the mission statement of each department or organization. This information will also include how the findings will provide a higher quality education for students.

The study will also be shared with a journal with a focus on students with special needs to inform educators, parents, and advocates about the findings of the study. Some of these journals could include Journal of Special Education, Rural Special Education 
Quarterly, Council for Exceptional Children, Journal of Educational Leadership, and Assessment for Effective Intervention. Rural Special Education Quarterly might be the best fit due to addressing issues in a rural area, which is the sample population that will be targeted for this study.

According to the political framework, the findings of this study will come from the grassroots of the issue; however, it is going to be important to influence people at the top in order to make a policy change (Bolman \& Deal, 2008). By developing and building relationships with both groups, it will be easier for change to occur (Kotter, 1982). The type of interaction between the groups will determine the influential tactic. The more socially accepted tactic would be to use rational arguments, personal appeals, and ingratiation to influence those in power (Levi, 2014). By providing the findings of the study combined with the personal perceptions of teachers and students, leaders are more likely to listen and take heed which could lead to a more probable outcome for policy change.

As with any suggestion for policy change, it is likely there will be some obstacles. Within the realm of public education, there is tension between professional and public control of key aspects of schooling as some do not feel public education is as responsive, equitable, and productive as it can be (Malen, 2011). As for an elected official, it could be helpful or hurtful within the campaign trail to endorse a change in social or educational issues (Fuhrman, 1993). With this issue regarding a small percentage of students throughout the state, it may be difficult for a politician to pursue this change when other educational reforms may address the needs of more students and gain political support from a larger population. According to Cohen and Moffitt (2011), "the 
absent infrastructure of practice deprived practitioners of instrument that would enable common problem solving and close communication, and it deprived policymakers and others of means to learn about and shape teaching and learning" (p. 78). Therefore, as educators within the public school system and experts within the field of special education, it is crucial that problems within the educational setting be identified and analyzed in order to be able to communicate implications within the system. Educators, administrators, advocates, and interest groups within the realm of education who have expertise power should be communicating openly with those in power that can execute change.

\section{Summary}

Equity arguments become credible when policy analysis has shown that citizens are not given equal access to policy procedures, whereas, the "equality of educational opportunity has often been a neglected issue and, not infrequently, an intentionally abused right" (Mitchell, 2011, p. 21). Shaping educational policy and making sure these policies are equitable are goals of some educational leaders at the federal, state, and local levels. By knowing one's strengths and weaknesses, standing firm on one's moral standards and values, exploring other's perspectives, and communicating openly, an authentic leader is more predisposed to facilitate the process of shaping educational policy. Although our governmental structures have shaped educational policy within the area of assessing students with special needs, there still may need to be ways to improve to gain more insight into how well these students are retaining knowledge and skills. If needed, the vitality of shaping these policies will be within the realm of identifying key stakeholders and influencing those in power (Levi, 2014). 
SECTION THREE:

SCHOLARLY REVIEW FOR THE STUDY 
In the fall of 2013, there were 5,693,441 North American students between the ages of six and twenty-one who received services under the Individuals with Disabilities Education Act, Part B (Institute on Disability, 2016). That number represents $8.4 \%$ of the total student population across the United States. Special education services covers a wide variety of disabilities and features instruction and interventions needed to meet the need of individual students. The types of services offered have progressed throughout the years from separate classroom settings to more inclusive environments. Today, there is more of a focus on equitable education for all students. Although there have been policies and procedures on how to fairly assess students with special needs, this topic is still relatively new with few studies focused on how state-mandated assessments affect students with special needs.

\section{History of Special Education}

In 1975, U. S. Congress enacted the Education for all Handicapped Children Act, otherwise known as Public Law 94-142. Prior to this landmark law, many students with special needs were placed in institutions and received minimal care for basic needs rather than education or rehabilitation (U.S. Department of Education, 2010b). Instructional strategies began to develop which laid the foundation for the beginning stages of intervention. In the 1970's, many states continued laws that excluded students with certain special needs from attending public schools; however, Public Law 94-142 guaranteed (a) a free appropriate public education with related services, (b) protected rights of students with special needs and their parents, (c) assistance for states in providing an education for all students with disabilities, and (d) assessment and assurances to measure the effectiveness to educate all students with special needs (U. S. 
Department of Education, 2010b). Beginning in the 1980's and 1990's, there was an increase in providing services for children with special needs beginning at birth. Additionally, transitional plans at the high school level were implemented to provide a smooth progression from school to the workforce, military, or postsecondary education/training. At this time, students were no longer isolated to separate classes, but started becoming more included within the regular classroom setting with supports from class within a class and other instructional programs. A class within a class program involves both a regular education teacher and a special education teacher in the same classroom assisting all students, regardless of academic achievement or functional performance. This allowed students with disabilities a better opportunity to access the general curriculum that became an accountability measure for schools.

Government officials have developed policies in an attempt to hold schools more accountable for increasing student achievement for all students by constructing a framework of goals, standards of school performance, a way of measuring school performance, and a system of rewards and sanctions based on school performance (Hanushek \& Raymond, 2001). The Rehabilitation Act of 1973 prohibited discrimination on the basis of disability in programs that received federal funding. The Outstanding Schools Act of 1993 (Missouri Governor's Office, 1993) established new statewide performance standards, held public schools accountable for student performance, and attempted to increase financial equity in Missouri public schools by adjusting the funding formula. The No Child Left Behind Act of 2001 required states to increase student achievement by having all students perform at "proficient" levels on state assessments by the 2013-2014 school year. According to that criteria, about $82 \%$ of schools across the 
United States and $81.9 \%$ of Missouri public schools would have been labeled as failing in the 2010-2011 school year (McNeil, 2011). More recently, the Missouri Department of Elementary and Secondary Education (DESE) developed Missouri School Improvement Program (MSIP 5) requirements. According to DESE (2014), the Missouri Assessment Program (MAP) was designed to monitor student performance on skills and knowledge based on the Missouri Learning Standards (MLS). Assessment data provides information at the student, class, school, district, and state levels, as well as, identifies individual strengths or weaknesses in relation to student performance on MLS. Students in Missouri are required to take four End-of-Course exams (EOCs) in Algebra I, Biology, English II, and Government prior to graduation. Additional EOCs are available in Algebra II, Geometry, English I, American History, and Physical Science and may be given at the discretion of the local school district (DESE, 2015c). Students with special needs who have been determined eligible to take an alternative assessment, English Language Learners (ELL), foreign exchange students, homeschool students, or students attending private schools may be exempt from EOC exams. As stated previously, an alternative assessment may be given to students with significant cognitive disabilities. Nevertheless, students with special needs who do not qualify for an alternative assessment are given the same assessment and are held accountable to perform at the same level of their peers, regardless of their ability levels.

Testing accommodations may be determined by a student's Individualized Education Plan (IEP) team to assist the student in communicating concepts learned. Although testing accommodations may be granted, these adjustments do not always assist the student in communicating the student's knowledge. The testing accommodations on 
state and national standardized tests do not always align with the testing accommodations used in the classroom. According to the Department of Elementary and Secondary Education (DESE, 2015i), accommodations should be utilized during instruction in the classroom, on classroom assessments, and on state and federal assessments to reduce or eliminate the effects of a student's disability; however, accommodations should not reduce learning expectations. Through analysis of student performance on assessments and adjusting accommodations to fit individualized needs, students will have an opportunity to perform better on all assessments (Cox, Herner, Demczyk, \& Nieberding, 2006). The Missouri Assessment Program (MAP) measures "how well students acquire the skills and knowledge described in Missouri's Learning Standards (MLS)" (DESE, 2015c). In 2008-2009, high school MAP assessments were changed to End-of-Course (EOC) assessments. Students were assessed at the end of each course in Government, Algebra I, English II, and Biology. Although other courses were added and assessed at different times, the state currently requires only those four subject areas to be assessed. English I, Geometry, Algebra II, and American History EOCs are now given at the discretion of the local education agency. Assessment data can be disaggregated at the student, class, school, district, and state levels, as well as within subgroups of gender, race/ethnicity, socioeconomic, and IEP status. Student performance scores are categorized as advanced, proficient, basic, and below basic. This information assists in determining the adequate yearly progress at the local, state, and federal levels.

The No Child Left Behind Act of 2002 and the 2004 Individuals With Disabilities Education Improvement Act (IDEIA 2004) have emphasized the importance of closing the achievement gap between students with special needs and their same-aged peers. 
Closing this gap is essential by providing an equitable education for all students. Regardless of personal traits, every student has the right to fair and equal treatment through our political system and educational organizations. Understanding how statemandated assessments affect student's with special needs, including positive and negative aspects, can be monitored through an impact of policy study (Bennett \& Jessani, 2011). Achievement equity, assessment equity, and Maslow's Hierarchy of Needs will be utilized to study impact within this case study.

\section{Current Status of Special Education in the United States}

On December 10, 2015, the new Every Student Succeeds Act (ESSA) was signed into law and will go into effect for the 2017-2018 school year. The ESSA replaced the No Child Left Behind Act and covers multiple areas from accountability standards and low performing schools to testing, funding, and teachers.

Each year states must provide an accountability plan to the U.S. Department of Education. States are allowed to develop their own long-term, short-term, and interim goals. These goals should close achievement gaps of students who are furthest behind and address graduation rates. These goals must include three academic indicators: proficiency on state assessment, English-language proficiency, and one other academic factor broken out by subgroup. In addition, states are given the opportunity to add another indicator of their choice, such as school/climate safety, student engagement, access to and completion of advanced courses, and a few others. For high schools, graduation rate must be addressed.

The U.S. Department of Education requires students to be tested in reading and math in 3rd grade through 8th grade and at least one assessment at the high school level. 
In Missouri, the high school assessment is American College Testing (ACT) which assesses high school achievement and college readiness. Although there are testing accommodations, such as extended time or reading of some parts of the test, the same assessment is given to all students, even students with special needs. For students with more severe needs, only $1 \%$ of the students at each building level can be given an alternative assessment.

According to the U.S. Department of Education (2016), schools must have an evidence-based plan to help subgroups of students who are struggling, such as minority students or students with special needs. If a school district is chronically underperforming, a comprehensive improvement plan must be developed and monitored for an unspecified amount of time. When an improvement plan is put into place for a school district, up to $7 \%$ of Title I funds may be used for school improvement to assist in closing the achievement gap of students who are struggling.

Achievement equity. Achievement equity and closing the gaps in student performance are important concepts to educators. With state and federal accountability measurements that either recognize high performing schools or reprimand lower performing schools, success for every student is at the forefront for educators. Equity auditing is a fairly new tool administrators can use to decrease the likelihood that inequalities will occur. Although many educators, parents, and others do not want to address the fact that inequalities occur within the public school system, equity must be addressed in order to close achievement gaps (Elliott, Braden, \& White, 2001; Skrla, Scheurich, Garcia, \& Nolly, 2004). IDEA (2004) intended to provide educational access to all students in order to benefit from educational programs and services. For the 
purpose of this study, achievement equity will focus on student performance on EOC assessment.

Achievement equity can be measured in a variety of ways. O’Neill (1976) measured equity in terms of outcomes (standards-based grading, assessments, etc.) rather than inputs (instruction, accommodations, etc.). Two studies agreed with this concept and later identified outcomes based on horizontal and vertical equity (Berne \& Stiefel, 1984; Stone, 2002). Horizontal equity was interpreted to have equal inputs, whereas, vertical equity assumed that different or unequal inputs attained equal outcomes (Stone, 2002). Students learn differently or learn at varied paces which may result in the need for unequal treatment, such as various modifications and accommodations.

Classroom modifications and testing accommodations are based on a student's individual needs and assist in providing additional support for students with special needs. Modifications and accommodations are made by a student's Individual Education Program (IEP) team which generally consists of parents/guardians, student, local education agency, special education teacher, regular classroom teacher, individual interpreting instruction implications of evaluation results, and other representatives from outside agencies, when needed (DESE, 2015h). The IEP team looks at various performance and assessment data to determine which modifications and accommodations are appropriate for the student. "An accommodation is used when the teacher believes that the student can achieve the same level of participation or accomplishment as the rest of the class, but just needs some additional support” (Darrow, 2007, p. 33). DESE (2014) noted "accommodations are changes in procedures or materials that increase equitable access" and "modifications are changes in procedures or materials that change the 
construct of the educational task making it difficult to compare results with typical peer results" (Form F).

Hollenbeck (2002) identified four attributes to distinguish between accommodations and modifications: unchanged constructs, individual need, differential effects, and sameness of inferences. According to Kettler (2012), unchanged constructs referred to not changing the skills or knowledge that the assessment is intended to measure. McDonnell, McLaughlin, and Morrison (1997) indicated testing accommodations are intended to offset distortions of test performance caused by a disability without invalidating or changing what the assessment is intended to measure. Individual need indicated that the test taker would be provided accommodations needed to offset skill deficits (Elliott et al., 2001; Kettler, 2012). McKevitt and Elliott (2003) referred to this as removing barriers created by the disability. Differential effects signified students with special needs would benefit more from the accommodation than most students taking the test and sameness of inference occurs when accommodations result in comparable scores which better assist educators in decision making (Kettler, 2012).

Valenzuela, Copeland, Huaqing Qi, and Park (2006) conducted a quantitative study on educational equity in a large southwestern school district. Utilizing pre-existing data, the researchers identified 17,834 students who received special education services and met the eligibility variable. SPSS software was used to analyze relationships between ethnicity and language proficiency status to type and number of disability labels, educational placement, and services received. This study indicated students with special needs are sometimes segregated from their peers and have limited access to the general 
curriculum. Data were further disaggregated to determine that minority and LEP students experience further inequities in educational opportunities (Lee, 2012; Skiba et al., 2008; Valnezuela et al., 2006). When opportunities to access the general curriculum are limited, students should not be expected to perform as well as their peers who have access to the curriculum. Although data used within this study were reported to state and federal entities, Valenzuela et al. (2006) noted there may be some errors in data entry within the student database system and findings should be interpreted with caution. Therefore, the findings were inconclusive and more studies need to be conducted in order to validate the findings within this study. This study focused more on identification, placement and services received rather than services and accommodations needed within the classroom. Although some participants were removed from the participant sample, the severity of disabilities and accommodations of the remaining participants were not addressed.

In McLaughlin's (2010) study on educational equity and students with special needs, longitudinal data raised some concerns on the level of benefits students with special needs were receiving from public education. According to the National Center for Educational Outcomes (2007), 56\% of high school students with special needs scored at the lowest level of performance in mathematics and 52\% of high school students with special needs scored at the lowest level of performance in reading/language arts. "The implications are that requiring each student with a disability to meet the same standards may, in fact, be inequitable" (McLaughlin, 2010, p. 274). Although this study of preexisting data was interesting, a comparison of how students with special needs and 
students without special needs performed over multiple years, instead of one assessment given on one particular day, would provide more clarification.

Assessment equity. Assessment equity is a concern for government officials as well as educators. It is important to ensure all students are given the same opportunity to exhibit their knowledge without having an advantage or disadvantage over another student. In the educational field, "equity in assessment is necessary to ensure students are not advantaged or disadvantaged in demonstrating their achievement, whether on the basis of meeting established achievement standards, or in comparison to other students" (Cumming \& Dickson, 2007, p. 201; DESE, 2015c). Additionally, DESE (2015) adds that assessments should identify areas for improvement for specific groups of students.

Some accommodations within the area of assessment may include oral exams, short answers, extended time, reduced length, open book exams, modified format, record student responses, alternative setting, and accommodations (DESE, 2015i). It is important to ensure that the accommodations do not alter what the test measures or the comparison of scores with students without special needs (Bowen \& Rude, 2006). However, when additional accommodations are given to students on a daily basis in the classroom setting that are not allowable on state assessments, students with special needs become even more disadvantaged. Although these accommodations attempt to give support so students can perform at the same level as their peers, they often become more debilitating and increase the achievement gap. Students become more reliant upon these modifications which often do not exist within some standardized assessments.

Fuchs, Fuchs, Eaton, Hamlett, and Karns (2000) conducted a qualitative study of the effects of accommodations, for students with and without disabilities, on a series of 
mathematics tests, teacher judgments in determining accommodations, and the benefits of formulating a standardized, data-base set of rules for formulating individual accommodations. The participant sample included 373 elementary students of which about half were not identified with a disability and the other half were diagnosed with a learning disability. A series of teacher-approved curriculum-based measurements (CBMs) in mathematics were given with varying accommodations. Findings indicated teachers gave a large number of accommodations to students; however, the students failed to profit from those accommodations. Also, the students who benefited the most did not have a disability that intertwined with mathematics. It was noted that during the study, some teachers denied accommodations to some students. Without these accommodations, students may be denied the opportunity to express their knowledge. The study utilized a database assessment process to analyze student performance scores in order to identify which accommodations were assisting students and which students needed additional assistance. Although methods of the study appeared valid and reliable, the findings and implications were limited. Limitations of the study were not identified. Smith and Gorard (2006) conducted a qualitative study of 5,432 students in five countries utilizing a questionnaire. Students responded to the items on the questionnaire and were given opportunities to write comments. According to this survey, students believe an equitable national education system should be egalitarian in which all students benefit equally. Students in the United Kingdom felt everyone should be treated in the same way. While pupils in other countries wanted the least able to receive more teacher attention in class, they reported that the most able were given more attention in class. This study indicated there was a difference between the personal experience of the 
participants and the treatment of minorities (Smith \& Gorard, 2006). Students expressed belief in that all students should benefit equally; however, the study did not offer suggestions regarding practical strategies nor was there quantitative data to support the findings. All data were self-reported by students.

In order to get an accurate measurement on an equitable assessment, a student should be assessed in a fair and comparable way. For example, accommodations for an assessment need to be utilized in daily testing to allow the student time to experience individualized testing accommodations. When state assessments are administered, student accommodations do not always transpose. Students who have become acclimated to accommodations necessitate the need to use those in standardized assessments. However, that may not be allowed in practice. For instance, students who have utilized a modification of open book or use of technology on assessments may not have information stored within memory and come to rely on looking up answers to questions. In this case, students are at a disadvantage if unable to access information during an assessment in the same manner in which they have been accustomed. Therefore, the student may become confused and at a loss of how to approach the assessment.

There have been multiple studies within the last fifteen years on how assessment accommodations, when mirrored with instructional accommodations, affected student performance on assessments (Bowen \& Rude, 2006; Malmgren, McLaughlin, \& Nolet, 2005; Shaftel, Xiangdong, Glasnapp, \& Poggio, 2005). McKevitt and Elliott (2003) studied the effects and consequences of read-aloud accommodation on reading test scores. According to this study, the individualized accommodations had minimal benefit for groups of students with and without disabilities. The perceptions of students and 
teachers expressed mixed feelings towards accommodations in general. Although students with special needs preferred the accommodated assessment, many of them expressed frustration having the test read-aloud. Teachers expressed that testing accommodations were somewhat helpful for students with special needs and somewhat agreed accommodations helped students with special needs feel more positive about the assessment. However, the generalizability of this study was limited as this study only focused on the read-aloud accommodation on a reading test. When professionals make decisions regarding assessment accommodations, the construct measured by the test, how the construct interacts with a student's disability, and accommodations to remove barriers created by the disability should be considered (McKevitt \& Elliott, 2003). Additionally, if a student continuously receives low scores compared to peers, there could be some long-term effects regarding motivation and esteem issues.

Maslow's hierarchy of needs. Students with special needs face many challenges as they progress through their school years into adulthood. Having a disability often has a negative connotation which can affect a student's self-esteem and motivation (Darrow, 2014). Many students with special needs perceive academics as a venue for failure and frustration derived from frequent failures (Margolis \& McCabe, 2004). When students with special needs achieve low scores, their confidence may be damaged (Kossar, Mitchem, \& Ludlow, 2005).

The theory of human motivation supported by Maslow's Hierarchy of Needs can be utilized to determine the impact of state-mandated assessments given to students with special needs based upon esteem needs. According to Maslow (1943/2005), most people have a desire for a high-evaluation of themselves in the areas of self-respect, self-esteem, 
and esteem of others. These needs can be classified into two categories: (a) "the desire for strength, for achievement, for adequacy, for confidence in the face of the world, and for independence and freedom" (Maslow, 1943/2005, p. 171); and, (b) "the desire for reputation or prestige (defining it as respect or esteem from other people), recognition, attention, importance or appreciation" (Maslow, 1943/2005, p. 171). Therefore, students desire high self-esteem from themselves, while at the same time, desiring respect and esteem from others. However, desire and motivation can be diminished when continuously faced with failing test scores (Elliott, Braden, \& White, 2011). When students have more of a fixed mindset and they continuously hit obstacles, setbacks, or criticisms, they gain more proof that they do not have the abilities that they desire (Dweck, 2006).

Zisimopoulos and Galanaki (2009) studied a group of 5th and 6th grade students with learning disabilities (LD) utilizing one-way analyses of variance (ANOVAs). Students with learning disabilities were compared to their typically achieving peers regarding intrinsic motivation and perceived academic competence. This study by Zisimopoulos and Galanaki (2009) found students with learning disabilities have more motivational deficits compared to their typically achieving peers; however, the students with special needs still maintained their curiosity for learning within the classroom. This study was limited by cross-sectional data and a small sample size within a particular geographic location. Additionally, the assessment of student intrinsic motivation and perceived academic competence was based on self-reporting and did not include teacher input. Although it is vital to have student perceptions to gain insight in how state mandated assessment for all students affects students, it is also important to analyze the 
perceptions of teachers who observe hundreds or thousands of students with special needs throughout their careers while taking state assessments and receiving assessment scores.

\section{Summary}

State and federal governments develop educational policy which has created a universal system of accountability for schools to reach intended outcomes (McDavid et al., 2013). The No Child Left Behind Act, Outstanding Schools Act of 1993, Rehabilitation Act of 1973, and Missouri School Improvement Program (MSIP 5) are policies which have attempted to provide an equitable education for all students. However, this universal system of education that requires all students to take the same assessments does not take into account students who have special needs that perform, in some cases, significantly below grade level. "The inclusion of students with special needs in test-based accountability presents unique curricular challenges across all levels of the educational environment, which must be met in order to ensure equitable instruction and assessment of all students" (Kurz, Talapatra, \& Roach, 2012, p. 37). Having expectations that all students perform at advanced or proficient levels is simply inequitable (McLaughlin, 2010). However, state and federal policies establish high expectations and accountability measures. Depending on the severity of the student's disability, these high expectations might be unattainable for some students, although they can make progress towards those goals (Collins, et al., 2005). When students with special needs do not meet the high level of performance established by state and federal guidelines, the focus is directed at the district rather than the effects on the student (Omerod, 2007). 
Educators attempt to provide equitable education services by bridging the performance gap between special needs and students without disabilities (Skrla et al., 2004). According to Albus, Lazarus, and Thurlow (2015) from the National Center on Educational Outcomes at the University of Minnesota, students with special needs scored 32 to 41 percentage points below other students on state assessments during the 20122013 school year and the scoring gaps widened as students reached middle school and high school. By developing individualized accommodations in the classroom and during state mandated assessments, educators hope to eliminate the barriers that a disability creates and provide a fair opportunity for students with special needs to demonstrate what they know (Alegre \& Ferrer, 2006; Cox et al., 2006; Cumming \& Dickson, 2007;

Darrow, 2007; Kettler, 2012; McKevitt \& Elliott, 2003; Meyen et al., 2006;). Any testing accommodation can succeed or fail if it is not designed specifically to meet the needs of the student (Kettler, 2012; Lyons, 2004).

Although there have been multiple studies regarding assessments and accommodations, there has been limited research in the area of how low performance on state assessments affects students with special needs personally. Research and policy focus on the how public schools are effected through narrowed curriculum or accountability measures (DESE, 2015k; DESE, 2016b; Langenfeld, Thurlow, \& Scott, 1997; Strauss, 2014) or how teachers are effected through accountability of student performance (Shavelson,et al, 2010; Strauss, 2014). Qualitative research supported by quantitative data regarding the perceptions of teachers, parents, and students would be beneficial to understanding how students are affected when mandated to take an 
assessment above their ability level and continue to score significantly below their sameaged peers. 


\section{SECTION FOUR:}

\section{EXECUTIVE SUMMARY AND PRACTITIONER REPORT}

To be sent to:

Missouri Department of Elementary and Secondary Education Deputy Commissioner of Education

Director of Office of College and Career Readiness

Assistant Commissioner of Special Education

Communications Coordinator

Director of Assessment

Council for Exceptional Children

Missouri Vocational Rehabilitation

Missouri School Boards Association

Missouri Association of Secondary School Principals

Missouri Association of School Administrators 


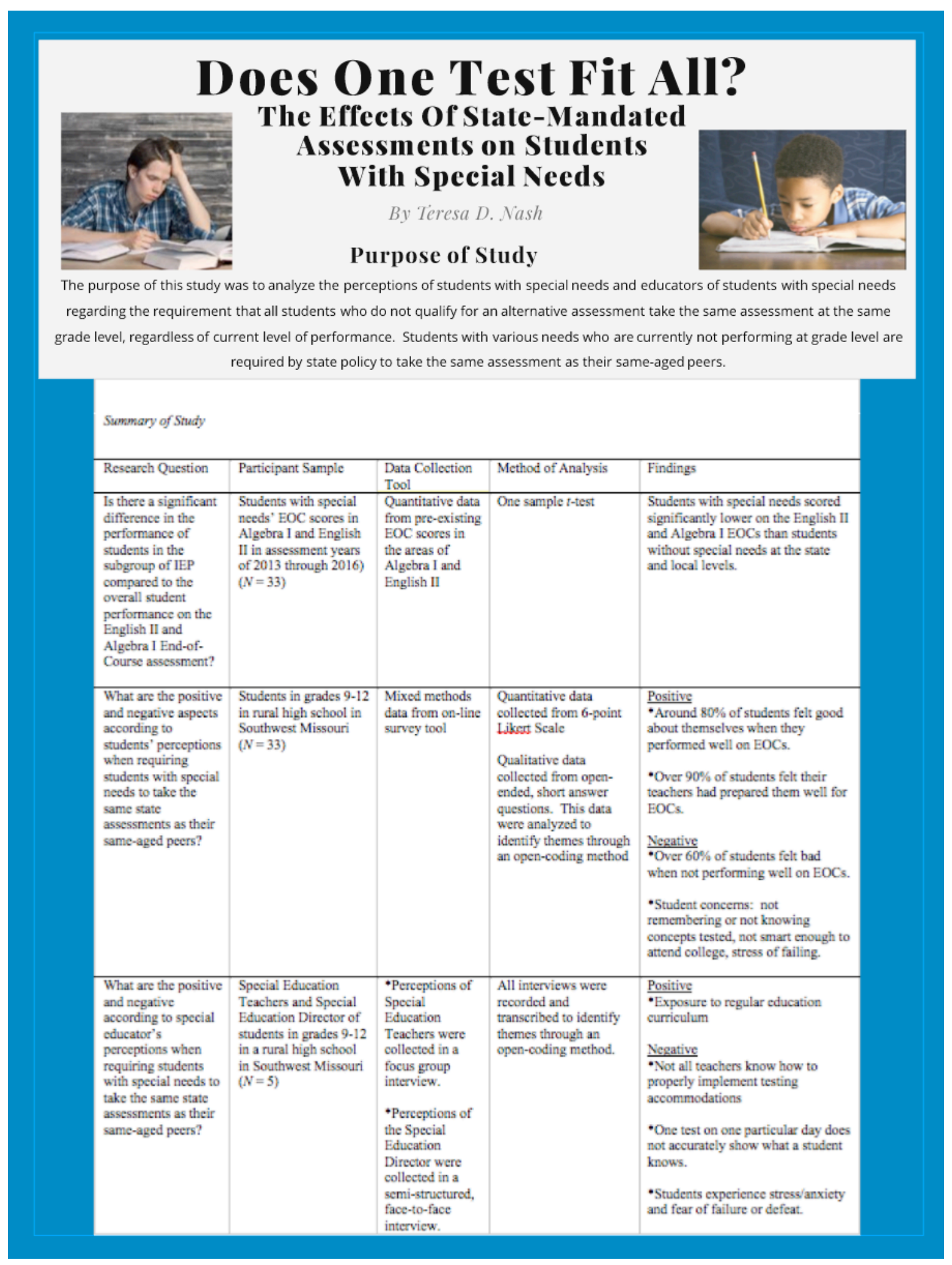




\section{Recommendations from Current Study \\ Special Education Teachers.}

1. Determine classroom modifications to meet the needs of edth sưuertit with special needs with input

from IEP team and student.

2. Teach students to become their own advocates regarding classroom modifications by reminding regular education teachers of their classroom modifications.

3. Use the same testing accommodations on a daily basis that will be used on state assessments.

4. Reduce text anxiety by reminding students that this is only one test that will assess their knowledge and there will be field questions asked about concepts in which they are not familiar to check for validity for the next school year (Willis, 2007).

5. Refer students to a Missouri Vocational Rehabilitation counselor to inquire about assistance in attending college, postsecondary training, and supported employment opportunities.,

\section{Administrators.}

1. Provide co-teaching classrooms in order to expose students to the regular education curriculum . Co-teaching is when a general education teacher and a regular education teacher share teaching responsibilities within a classroom for students with and without special needs (Wischnowski, Salmon, \& Eaton, 2004).

2. Provide professional development for teachers on how to effectively implement co-teaching.

3. Assist special education teachers in training regular education teachers on how to implement modifications.

Policy Makers.

1. Require benchmark or formative assessments throughout the school year rather than a summative test at the end of the year. "No single test does everything; thus, it is important to use multiple measures and repeated measurements" Elliott, Braden, \& White, 2001). Students must be given multiple opportunities to demonstrate proficiency (National Joint Committee on Learning Disabilities, 2004).

\section{Recommendations from Related Research}

Department of Elementary and Secondary Education and Other Policy Makers.

\section{ASSESSMENT}

Individualize assessments by providing alternative assessments for students with special needs regardless of the severity of their disability. Assess the same concepts and activities as same-aged peers; however, assess a little differently by (a) reducing the amount and complexity of information, (b) reducing construct-irrelevant language, and/or (c) supporting students' processing of information by segmenting

\section{Conclusion}

Test scores and measures of achievement indicate where a student is currently functioning, but do not indicate where a student could end up (Dweck, 2006). The purpose of special education is not to turn every student with special needs into a grade-level performer, but to allow a team of individuals to decide on a plan of action to help the student lead a happy, productive, independent life once they exit the school system (Lemons et al., 2012). In order to do so, policy makers must change the way students with special needs are assessed to encourage them to keep progressing, no matter how long it takes. One test does not fit all. It simply gives an accountability measure for schools, but does not take into consideration the unintentional outcome of suppressing students with special needs. Students with special needs require support and encouragement in order to be successful. A better approach would be to compare the scores of students with special needs on an individual basis for academic progress rather than comparing with same-aged peers. It is recommended that the policy of mandating state assessments for students with special needs be investigated and the policy implementation modified so all students can communicate their knowledge and show progress. 
Does one test fit all? School districts across the nation are held to accountability standards based on state-mandated assessments. As part of the Missouri School Improvement Program (MSIP 5), the intention of administering state-mandated assessments was to hold public schools accountable for student progress toward the Missouri Learning Standards (Department of Elementary and Secondary Education, 2015c). The No Child Left Behind Act of 2001 reinforced the necessity for all students to take state assessments, including students with special needs, and created a universal system of accountability for public schools (Malmgren, McLaughlin, \& Nolet, 2005). However, when creating and modifying policies that mandate all students take state assessments, are we, as a society, assisting or further marginalizing students with special needs?

State and federal governments develop educational policy regarding assessment procedures (Cohen \& Moffitt, 2011). These assessment policies are made by government officials which leave little or no room for autonomy within local education agencies and who often do not understand the educational environment enough to realize the impact of their policies (Omerod, 2007). This top-down approach (Bolman \& Deal, 2008) of developing policies without considering implications to all students could have a detrimental impact on specific subgroups, including students with special needs.

Government officials at both the state and federal level have developed numerous policies in an attempt to hold schools more accountable for increasing student achievement for all students. The Rehabilitation Act of 1973 prohibited discrimination on the basis of disability in programs that received federal funding. The Outstanding Schools Act of 1993 (Missouri Governor's Office, 1993) established new statewide 
performance standards, held public schools more accountable for student performance, and attempted to increase equity in Missouri public schools by adjusting the funding formula. The No Child Left Behind Act of 2001 required states to increase student achievement by having all students perform at "proficient" levels on state assessments by the 2013-2014 school year (Klein, 2015). According to this criteria, about 82\% of schools across the United States and $81.9 \%$ of Missouri public schools would have been labeled as failing in the 2010-2011 school year (McNeil, 2011).

More recently, the Missouri Department of Elementary and Secondary Education (DESE) developed Missouri School Improvement Program (MSIP 5) requirements. According to DESE (2015c), the Missouri Assessment Program (MAP) was designed to monitor student performance on skills and knowledge based Missouri Learning Standards (MLS). Additionally, DESE launched "Top 10 by 20", an improvement initiative that aims for Missouri to be among the top ten ranking states in the United States. This program analyzes the following goals: (a) the percentage of students scoring at or above the proficient level on the National Assessment of Educational Progress (NAEP); (b) the percentage of students will increase each year to meet the "on track" MSIP targets for all students; and (c) the percentage of students scoring below basic on state assessment will decrease (DESE, 2016b).

At the federal level, President Obama enacted the Every Student Succeeds Act (ESSA) which also monitors student performance on state assessments, sets performance targets, and holds schools accountable for their performance (U.S. Department of Education, 2016a). Data from these assessments provide information at the student, class, school, district, and state levels, as well as identify individual strengths and 
weaknesses. In order to meet the accountability standards of ESSA, students in Missouri are required to take four End-of-Course exams (EOCs) in Algebra I, Biology, English II, and Government prior to graduation. Additional EOCs in Algebra II, Geometry, English I, American History, and Physical Science may be given at the discretion of the local school district. Students with severe cognitive impairments, foreign exchange students, homeschool students, or students attending private schools may be exempt from EOC exams. English Language Learners (ELL) are only exempt from EOC exams for one school year. For this small percentage of the student population, an alternative assessment may be given. Nevertheless, students with special needs who do not qualify for an alternative assessment are still expected to perform at the same level of their peers, regardless of their ability levels.

\section{Statement of the Problem}

Not all students perform at the same level nor do they progress academically at the same rate. Therefore, why is it a requirement that we give all students the same assessment and expect every student to perform at proficient or advanced levels? Applying a statistical measurement in which students are classified by performance using single cut scores may advantage or disadvantage particular subgroups (Wyse, Dean, \& Viger, 2013). "Principles of quality assessment indicate that a variety of assessment activities should be undertaken to inform high stakes assessments" (Cumming \& Dickson, 2007, p. 208). Although many school districts assess student progress on multiple benchmark assessments each year, state and national assessments are assessed on a single end-of-course assessment. "Schools and in some instances students are held 
accountable for achieving specified levels of performance" (McLaughlin, Embler, Hernandez, \& Caron, 2005, p. 32).

Policy makers are challenged to ensure state assessments measure student performance and allow all students to demonstrate what they have learned (Meyen, Poggio, Seok, \& Smith, 2006). According to Cumming and Dickson (2007), "advantage or disadvantage occurs when standard assessment conditions and administration prevent students with a special learning need or disability from being able to demonstrate their learning achievement, where students without such needs or disabilities will not be so hampered" (p. 202). Depending on individual needs of students, testing accommodations may be determined by a student's Individualized Education Plan team to assist the student in communicating concepts learned to off-set skill deficits (Kettler, 2012). Although testing accommodations may be granted, these adjustments do not always assist the student in communicating what is known, especially if daily classroom accommodations do not mirror accommodation options for a specific test. When this occurs, students may become confused and at a loss of how to approach the assessment. This could affect how the student performs on an assessment and overall accountability scores for the district.

\section{Purpose of the Study}

The purpose of this study was to analyze the perceptions of students with special needs and educators of students with special needs regarding the requirement that all students who do not qualify for an alternative assessment take the same assessment at the same grade level, regardless of current level of performance. Students with various needs who are currently not performing at grade level are required by state policy to take the 
same assessment as their same-aged peers. The focus of this study was on the perceptions of students and teachers and how the continuous basic and below basic achievement levels have affected students' self-esteem and outlook for future goals. For the purpose of this study, participants were students with special needs who had been identified through academic and cognitive testing to receive an Individualized Education Program (IEP) and were provided services as identified by an IEP team (DESE, 2015a). This team included, but was not limited to, a special education director, a special education teacher, a regular education teacher, the student's parent/guardian, and the student (DESE, 2015b). Aspects of education equity (Alegre \& Ferrer, 2010; Skiba et al., 2008) assessment equity (Lyons, 2004) and advocacy (Kalyanpur, Harry, \& Skrtic, 2000) were investigated in this case study.

This mixed-methods study will assist policy makers and educators in understanding the effects that state-mandated assessments have on students with special needs through a case study in a small, rural school district in southwest Missouri. Preexisting data from student performance on Algebra I and English II EOCs were analyzed to determine effectiveness of testing accommodations on previous EOC assessments. Through personal interviews and surveys, students and educators reflected on their experiences and expressed their opinions on the impact of state-mandated assessments for students with disabilities.

\section{Research Questions}

The research questions guiding this study are: 
1. Is there a significant difference in the performance of students in the subgroup of IEP compared to the overall student performance on the English II and Algebra I End-of-Course assessment?

2. According to the students with special needs perceptions, what are the positive and negative aspects of requiring students with special needs to take the same state assessments as their same-aged peers?

3. According to the special educators' perceptions, what are the positive and negative aspects of requiring students with special needs to take the same state assessments as their same-aged peers?

\section{Design of the Study}

As shown in Table 1, the design of this case study followed a convergent parallel mixed methods procedure. According to Creswell (2014), a mixed methods approach involves collection, analysis, and interpretation of both quantitative and qualitative data. Through the synthesis of data, a researcher can gain a more complete understanding of a marginalized group by not only analyzing close-ended (quantitative) data, but also considering open-ended (qualitative) data to gain insights from human resources (Creswell, 2013). Through the convergent parallel mixed methods design, data were collected from both quantitative and qualitative measures, analyzed separately, and then compared to see if the data confirmed or disconfirmed each other (Creswell, 2014).

\section{Setting}

This study focused on a small, rural high school in southwest Missouri (450 students or less) in grades 9-12. This high school is located in a high poverty area with a free/reduced lunch percentage steadily reported at approximately $70 \%$ and enrollment has 
consistently decreased over the past several years (Department of Elementary and

Secondary Education, 2015b).

Table 1

Summary of Design of Study

\begin{tabular}{|c|c|c|c|}
\hline Research Question & Participant Sample & Data Collection Tool & Method of Analysis \\
\hline $\begin{array}{l}\text { R1: Is there a } \\
\text { significant difference } \\
\text { in the performance of } \\
\text { students in the } \\
\text { subgroup of IEP } \\
\text { compared to the overall } \\
\text { student performance on } \\
\text { the English II and } \\
\text { Algebra I End-of- } \\
\text { Course assessment? }\end{array}$ & $\begin{array}{l}\text { Students with special } \\
\text { needs' EOC scores in } \\
\text { Algebra I and English } \\
\text { II in assessment years } \\
\text { of } 2013 \text { through 2016) } \\
(N=33)\end{array}$ & $\begin{array}{l}\text { Quantitative data from } \\
\text { pre-existing EOC scores } \\
\text { in the areas of Algebra I } \\
\text { and English II }\end{array}$ & One sample $t$-test \\
\hline $\begin{array}{l}\text { R2: What are the } \\
\text { positive and negative } \\
\text { aspects according to } \\
\text { students' perceptions } \\
\text { when requiring } \\
\text { students with special } \\
\text { needs to take the same } \\
\text { state assessments as } \\
\text { their same-aged peers? }\end{array}$ & $\begin{array}{l}\text { Students in grades } 9-12 \\
\text { in a rural high school } \\
\text { in Southwest Missouri } \\
(N=33)\end{array}$ & $\begin{array}{l}\text { Mixed methods data from } \\
\text { on-line survey tool }\end{array}$ & $\begin{array}{l}\text { Quantitative data } \\
\text { collected from 6-point } \\
\text { Likert Scale } \\
\text { Qualitative data collected } \\
\text { from open-ended, short } \\
\text { answer questions. This } \\
\text { data were analyzed to } \\
\text { identify themes through } \\
\text { an open-coding method. }\end{array}$ \\
\hline $\begin{array}{l}\text { R3: What are the } \\
\text { positive and negative } \\
\text { according to special } \\
\text { educator's perceptions } \\
\text { when requiring } \\
\text { students with special } \\
\text { needs to take the same } \\
\text { state assessments as } \\
\text { their same-aged peers? }\end{array}$ & $\begin{array}{l}\text { Special Education } \\
\text { Teachers and Special } \\
\text { Education Director of } \\
\text { students in grades } 9-12 \\
\text { in a rural high school } \\
\text { in Southwest Missouri } \\
(N=5)\end{array}$ & $\begin{array}{l}\text { Qualitative data from } \\
\text { Special Education } \\
\text { Teachers' perceptions } \\
\text { were collected in a focus } \\
\text { group interview. } \\
\text { Qualitative data from } \\
\text { Special Education } \\
\text { Director's perception } \\
\text { were collected in a semi- } \\
\text { structured, face-to-face } \\
\text { interview. }\end{array}$ & $\begin{array}{l}\text { All interviews were } \\
\text { recorded and transcribed } \\
\text { to identify themes } \\
\text { through an open-coding } \\
\text { method. }\end{array}$ \\
\hline
\end{tabular}




\section{Participants}

Participants consisted of a convenience sample within a single stage sampling procedure of students in grades 9-12 who had been identified with a disability, but did not qualify for an alternative assessment. Data regarding these participants were collected between the years of 2013 through 2016. Additionally, a special education director and special education teachers served as participants and were purposefully selected from the chosen site through a convenience sample as well. Fink (2013) defined convenience sample as people who are willing to participate. These participants were chosen because of their role as key stakeholders within the setting as well as their expertise and experiences within special education. Each research question focused on different types of data and included different participants.

\section{Data Collection Tools}

Qualitative data were collected through surveys of students with disabilities, an interview with the special education director, and a focus group interview of special education teachers, as shown in Table 1. The purpose of these data collection tools was to gain insight into the perceptions of the participant sample. The interview with the special education director was conducted face-to-face with a semi-structured interview template. When interviewing special education teachers, a focus group was used. Krueger and Casey (2009) identified a focus group as a small group of participants who interact in a facilitated interview. Discussions are relaxed and non-threatening with participants' answers building off one another (Krueger \& Casey, 2009). All interviews were recorded and transcribed in order to identify emerging themes within responses. 
With the survey, quantitative data were collected to address research questions one and two. Quantitative data were assessed with a six-point Likert scale survey. Additional quantitative data collected included pre-existing data from End of Course (EOC) assessment scores in the English II EOC and Algebra I EOC from 2013-2016, as shown in Table 1. A comparison of scores was made between students with special needs and students without special needs at both the state and local levels.

In order to reduce the likelihood of bias, the investigator utilized a third party to contact potential participants. The third party proctor signed the Survey Proctor Confidentiality/Protocol/Privacy Agreement before contacting potential participants. The proctor who was neutral from the project read the recruitment script to the potential participants, along with the principal investigator's contact information for questions. Written consents, child assent forms, and parental consent forms were given to participants to take home to read and decide whether they wanted to participate in the study. The third party proctor collected all signed consents, assent and parental consent forms to give to the researcher to ensure that all assent and consents were in order prior to data collection (Creswell, 2014).

The purpose of the survey was to generalize information from a specific group of participants so inferences could be made regarding the effects of mandated assessments of students with special needs (Creswell, 2014). As shown in Table 1, participating students were administered an online survey. The online assessment tool was advantageous in the rapid turnaround of data collection (Creswell, 2014). Due to the sensitive nature of identifying thoughts and feelings of students with disabilities, student 
surveys were administered utilizing an online tool. Qualitative data were assessed within the surveys using open-ended, short answer questions.

\section{Data Analysis}

Within the participant school district, teaching positions have been absorbed whenever possible; however, the student to teacher ratio has remained steady at 13:1 (Department of Elementary and Secondary Education, 2015c). Over the past three years, the four-year and five-year graduation rates of students with special needs have been higher than the state average (2013-2015) with the majority of these students entering the workforce (Department of Elementary and Secondary Education, 2015d). In addition, students with special needs have scored lowered than their peers on state assessments between 2013-2016 (Department of Elementary and Secondary Education, 2015b).

Quantitative data within research question one were analyzed when comparing student performance scores on the English II and Algebra I EOCs through the logic model. The impact of the policy was analyzed between students with special needs and students without special needs. McDavid et al. (2013) stated the logic model assists in identifying intended results. Pre-existing data of EOC performance levels in the areas of English II and Algebra I of students with special needs and students without special needs were collected. Additionally, quantitative data were analyzed through a one-sample $t$-test that is utilized when "there are two experimental conditions and different participants were assigned to each condition" (Field, 2013). The average student performance was used as the test value and compared to a set of scores in the subgroup of IEP.

Quantitative data through surveys were analyzed through the use of SurveyMonkey, an on-line survey tool. Responses were collected through a six-point 
Likert scale, ranging in responses from strongly disagree to strongly agree. Frequencies and percentages of each response were recorded and used to clarify findings. This data were used to answer research questions two and three.

Qualitative data within research questions two and three were analyzed through the use of grounded theory. According to Creswell (2014), grounded theory "is a design of inquiry from sociology in which the researcher derives a general, abstract theory of a process, action, or interaction grounded in the views of participants" (p. 14). Interviews, focus groups responses, and open-ended questions on the survey were analyzed through an open-coding method. The researcher was open to any possible themes at this point; therefore, this process was referred to as open-coding (Merriam, 2009). Since the amount of data was immense, the researcher winnowed the data in order to focus on specific themes (Guest, MacQueen, \& Namey, 2012). Creswell (2014) identified saturation when data no longer provides new insights.

\section{Significance of the Study}

The University of Missouri encourages scholarly communication within books, journals, and electronic forms (Blanken, 2012). The purpose of this study is to gain knowledge of the effects that state-mandated testing has on students with special needs who do not qualify for an alternative assessment. Contributions to both scholarship and practice could be developed; however, communication of the findings might be more beneficial in the area of practice.

In the area of scholarship and practice, educational leaders and policy makers could benefit from this study by knowing the effects that state-mandated assessments have on students. What can we do differently to prevent adverse effects of administering 
the same test to students with different ability levels? How might the educational system test students at each student's ability level so all students may experience success rather than failure? How will this affect a student's self-esteem and encourage the student to look forward to possible college or career choices with optimism rather than a fear of failure?

When all students are tested at their ability level, it can provide valuable information on how to assist students individually to accomplish their postsecondary goals. By focusing on areas needed to prepare individual students for individualized college and career goals, assisting students at the level they are currently performing, and addressing the needs of each student at their ability level, educators would have a solid base on which to build and address the areas of deficit to make each student successful.

\section{Findings}

Research Question 1. A one sample $t$-test was conducted to compare student performance on the English II and Algebra I EOCs of students with special needs (IEP) to students without special needs (Non-IEP) at the state and local level (2013-2016).

As shown in Table 2, there was a significant difference in the scores at the state level for students with IEP $(M=191.550, S D= \pm 1.390)$ compared to students with NonIEP $(M=210.380, S D=1.802)$ conditions; $t=-12.504, p<.001$. There was a significant difference in the scores at the local level for students with IEP $(M=199.600, S D= \pm$ 4.854) compared to students with Non-IEP $(M=213.000, S D= \pm 3.869) ; t=-2.304, p=$ .030. These results suggest that students with special needs scored significantly lower than students without special needs on the English II EOC at both the state and local level for the years 2013 through 2016. 
Table 2

One Sample t-Test Between Students With IEP and Non-IEP at the State and Local Levels of 2013-2016 English II Performance

\begin{tabular}{ccccccc}
\hline Level & Category & $\begin{array}{c}\text { Mean } \\
\text { Scale } \\
\text { Score }\end{array}$ & $s d$ & $t$-Value & Probability & $\begin{array}{c}\text { Significant/ } \\
\text { Not } \\
\text { Significant } \\
\text { (alpha }=.05)\end{array}$ \\
\hline State Level & IEP & 191.550 & \pm 1.390 & -12.504 & $p<.001$ & Significant \\
& Non-IEP & 210.380 & \pm 1.802 & & & \\
Local Level & IEP & 199.600 & \pm 4.854 & -2.304 & $p=.030$ & Significant \\
& Non-IEP & 213.000 & \pm 3.869 & & & \\
\hline
\end{tabular}

Note. (State IEP $N=25,831$; State Non-IEP $N=234,583$; Local IEP $N=39$; Local Non-IEP $N=380$.)

Table 3

One Sample t-Test Between Students With IEP and Non-IEP at the State and Local Levels of 2013-2016 Algebra I Performance

\begin{tabular}{ccccccc}
\hline Level & Category & $\begin{array}{c}\text { Mean } \\
\text { Scale } \\
\text { Score }\end{array}$ & $s d$ & $t$-Value & Probability & $\begin{array}{c}\text { Significant/ } \\
\text { Not } \\
\text { Significant }\end{array}$ \\
\hline State Level & IEP & 186.120 & \pm 3.071 & -9.858 & $p<.001$ & Significant \\
& Non-IEP & 206.150 & \pm 1.717 & & & \\
Local Level & IEP & 189.020 & \pm 1.357 & -6.353 & $p<.001$ & Significant \\
& Non-IEP & 204.350 & \pm 3.951 & & & \\
& & & & & & \\
\hline
\end{tabular}

Note. (State IEP $N=27,318 ;$ State Non-IEP $N=241,764$; Local IEP $N=42$; Local Non-IEP $N=337$.)

As shown in Table 3, there was a significant difference in the scores at the state level for students with IEP $(M=186.120, S D= \pm 3.071)$ and students with Non-IEP $(M=$ 206.150, $S D=1.717$ ) conditions; $t=-9.858, p<.001$. There was a significant difference in the scores at the local level for student with IEP $(M=189.020, S D= \pm 1.357)$ and 
students with Non-IEP $(M=204.350, S D= \pm 3.951)$ conditions; $t=-6.353, p<.001$. These results suggest that students with special needs scored significantly lower on the Algebra I EOC than students without special needs.

Research Question 2. Qualitative data were obtained through an on-line survey to gain perceptions of students with special needs regarding the state requirement of taking state assessments. Nineteen students responded to the survey (see Table 4).

Students were asked about classroom modifications and testing accommodations given on a daily basis in the educational setting. About $84 \%$ of students indicated they slightly to strongly agreed they received classroom modification to assist them with their daily work.About $84 \%$ of students indicated they agreed to strongly agreed they received special accommodations when taking a test. About $94 \%$ of students slightly to strongly agreed their teachers had prepared them to do well on EOCs.

When asked about state assessments, about $84 \%$ of students slightly to strongly agreed they had participated in an End-of-Course (EOC) exam. Of those students, about 55\% slightly agreed or agreed that they scored as well as or better than other students on the EOC. Regarding students who had taken an EOC, about $61 \%$ were recognized in an assembly or received an award for doing well.

Students were asked about their performance on the Algebra I EOC, English II EOC, and the ACT. About $77 \%$ of students felt good about themselves when they performed well on the Algebra I EOC. Most students indicated their scores would show them how much they had learned in the Algebra I course. About $83 \%$ of students felt good about themselves when they performed well on the English II EOC. These students felt the English II EOC results would show how much they had improved in the course 
Table 4

Does One Test Fit All?

Student Survey Statements and Responses

\begin{tabular}{|c|c|c|c|c|c|c|}
\hline & $\begin{array}{l}\text { Strongly } \\
\text { Disagree }\end{array}$ & Disagree & $\begin{array}{l}\text { Slightly } \\
\text { Disagree }\end{array}$ & $\begin{array}{l}\text { Slightly } \\
\text { Agree }\end{array}$ & Agree & $\begin{array}{l}\text { Strongly } \\
\text { Agree }\end{array}$ \\
\hline 1. I receive classroom modifications to & 2 & 1 & 0 & 2 & 8 & 6 \\
\hline assist with my daily work. & $11 \%$ & $5 \%$ & $0 \%$ & $11 \%$ & $42 \%$ & $32 \%$ \\
\hline 2. When taking a test, I receive special & 2 & 1 & 0 & 0 & 8 & 8 \\
\hline $\begin{array}{l}\text { accommodations (e.g., go to another } \\
\text { classroom, have test read, extended } \\
\text { time, etc.) }\end{array}$ & $11 \%$ & $5 \%$ & $0 \%$ & $0 \%$ & $42 \%$ & $42 \%$ \\
\hline 3. I will take or have taken an End of & 3 & 0 & 0 & 2 & 5 & 9 \\
\hline Course Exam (EOC). & $16 \%$ & $0 \%$ & $0 \%$ & $11 \%$ & $26 \%$ & $47 \%$ \\
\hline 4. I feel like I score as well as or better & 3 & 3 & 2 & 5 & 5 & 0 \\
\hline than other students on EOCs. & $17 \%$ & $17 \%$ & $11 \%$ & $28 \%$ & $28 \%$ & $0 \%$ \\
\hline 5. I am recognized in an assembly or & 3 & 2 & 2 & 5 & 3 & 3 \\
\hline get a reward for doing well on EOCs. & $17 \%$ & $11 \%$ & $11 \%$ & $28 \%$ & $17 \%$ & $17 \%$ \\
\hline 6. I feel good about myself when I do & 1 & 3 & 0 & 1 & 6 & 7 \\
\hline well on the Algebra I EOC & $6 \%$ & $17 \%$ & $0 \%$ & $6 \%$ & $33 \%$ & $39 \%$ \\
\hline 7. I feel good about myself when I do & 2 & 1 & 0 & 2 & 6 & 7 \\
\hline well on the English II EOC. & $11 \%$ & $6 \%$ & $0 \%$ & $11 \%$ & $33 \%$ & $39 \%$ \\
\hline 8. I feel good about myself when I do & 1 & 1 & 1 & 1 & 9 & 6 \\
\hline well on the ACT. & $5 \%$ & $5 \%$ & $5 \%$ & $5 \%$ & $47 \%$ & $32 \%$ \\
\hline 9. I receive the same accommodations & 1 & 1 & 0 & 6 & 7 & 2 \\
\hline $\begin{array}{l}\text { for a test in the classroom as I do when } \\
\text { taking an EOC. }\end{array}$ & $6 \%$ & $6 \%$ & $0 \%$ & $35 \%$ & $41 \%$ & $12 \%$ \\
\hline 10. If I do not do well on an EOC, I & 1 & 3 & 1 & 5 & 3 & 4 \\
\hline feel bad. & $6 \%$ & $18 \%$ & $6 \%$ & $29 \%$ & $18 \%$ & $24 \%$ \\
\hline 11.If I do not do well on the Algebra I & 5 & 4 & 2 & 3 & 3 & 1 \\
\hline $\begin{array}{l}\text { EOC, I feel like I will not be successful } \\
\text { after high school. }\end{array}$ & $28 \%$ & $22 \%$ & $11 \%$ & $17 \%$ & $17 \%$ & $6 \%$ \\
\hline 12. If I do not do well on the English II & 4 & 5 & 3 & 4 & 1 & 1 \\
\hline $\begin{array}{l}\text { EOC, I feel like I will not be successful } \\
\text { after high school. }\end{array}$ & $22 \%$ & $28 \%$ & $17 \%$ & $22 \%$ & $6 \%$ & $6 \%$ \\
\hline 13. If I do not do well on the ACT, I & 4 & 3 & 2 & 5 & 1 & 4 \\
\hline $\begin{array}{l}\text { feel like I will not be successful after } \\
\text { high school. }\end{array}$ & $21 \%$ & $16 \%$ & $11 \%$ & $26 \%$ & $5 \%$ & $21 \%$ \\
\hline 14. My score on the EOC does not & 1 & 3 & 1 & 5 & 6 & 2 \\
\hline $\begin{array}{l}\text { affect how successful I will be after } \\
\text { high school. }\end{array}$ & $6 \%$ & $17 \%$ & $6 \%$ & $28 \%$ & $33 \%$ & $11 \%$ \\
\hline 15. I feel like my teachers prepare me & 1 & 0 & 0 & 5 & 5 & 7 \\
\hline to do well on EOCs. & $6 \%$ & $0 \%$ & $0 \%$ & $28 \%$ & $28 \%$ & $39 \%$ \\
\hline 16. After high school I plan on going & 2 & 1 & 1 & 1 & 6 & 8 \\
\hline to college. & $11 \%$ & $5 \%$ & $5 \%$ & $5 \%$ & $31 \%$ & $42 \%$ \\
\hline 17. After high school I plan on going & 4 & 7 & 2 & 4 & 0 & 2 \\
\hline to vocational training. & $21 \%$ & $37 \%$ & $11 \%$ & $21 \%$ & $0 \%$ & $11 \%$ \\
\hline 18. After high school I plan on going & 9 & 6 & 3 & 1 & 0 & 0 \\
\hline to the military. & $47 \%$ & $32 \%$ & $16 \%$ & $5 \%$ & $0 \%$ & $0 \%$ \\
\hline 19. After high school, I plan on getting & 1 & 0 & 0 & 3 & 7 & 8 \\
\hline a job. & $5 \%$ & $0 \%$ & $0 \%$ & $16 \%$ & $37 \%$ & $42 \%$ \\
\hline
\end{tabular}

Note. $N=19$. 
and how well they could spell and write. About $84 \%$ felt good about themselves when they performed well on the ACT. Participants indicated ACT results would help them get into their college of choice or would show how well they might perform in college. When taking the EOC, about $88 \%$ of students slightly to strongly agreed they received the same accommodations for a test in the classroom as they did when taking an EOC.

Students were asked about their perceptions if they did not do well on EOCs or the ACT. About $72 \%$ of students slightly to strongly agreed the EOC does not affect how successful they would be after high school. About $70 \%$ of students indicated they slightly to strongly agreed they felt bad if they did not perform well on an EOC. About $61 \%$ of students slightly to strongly disagreed they would not be successful after high school if they did not perform well on the Algebra I EOC. Most students were concerned about not knowing the concepts or not performing well on the Algebra I EOC. About $67 \%$ of students slightly to strongly disagreed they would not be successful after high school if they did not perform well on the English II EOC. Participants indicated they were concerned about not remembering or knowing the concepts and fear of not scoring well. About $52 \%$ of students slightly to strongly agreed they would not be successful after high school if they did not do well on the ACT. Some concerns included not being smart enough to go on to college, stress of failing, and not being allowed to go on to college if their score was not high enough.

Postsecondary plans were addressed in the on-line survey. About $79 \%$ of the students surveyed indicated they slightly to strongly agreed they had plans to attend college, about $31 \%$ slightly to strongly agreed on plans for vocational training, about $5 \%$ 
slightly to strongly agreed joining the military, and about $95 \%$ had plans of getting a job after high school.

Research Question 3. Qualitative data to gain the perceptions of special educators were collected through a personal interview of the special education director and a focus group discussion of three special education teachers. The same questions were asked during each session.

Each person interviewed brought various perspectives to the topic. The special education director was in her first year and served as a process coordinator for three years prior. She was also a second grade teacher for ten years. Teacher A has over fifteen years of experience with mainly students with emotional disturbances or behavioral issues. Teacher B is in her third year of teaching special education students at the high school level and has had less than five years of experience teaching students with special needs at the elementary level. Teacher $\mathrm{C}$ is in his first year of teaching. His major in college was in social studies; however, he was hired on a temporary certification as a special education teacher. He has about three years of experience as a paraprofessional. Each of these teachers and the special education director indicated they had interest in assisting students with special education students. While some stated they like the challenge of a variety of daily activities to meet individual needs, others indicated they gained an interest through a life experience or because they just wanted to help students who were struggling. All of these educators indicated they feel working with students with special needs is most rewarding when they see students make connections, learn new concepts, and grow as individuals. 
In order to make decisions to assist students in learning, each of the educators indicated they involved a team of people to assist, such as parents, the student (depending on age), regular education teachers, special education teachers, administrators, counselors, and special groups. This group of individuals is known as the Individualized Education Plan (IEP) Team. All of these individuals assist in determining appropriate modifications to meet the needs of each student. In order to show students are making progress in academics, this team uses current level of performance to determine where the student is currently functioning and sets goals for student progress. Classroom modifications and testing accommodations are also determined to help the student express their knowledge. According to Teacher A, formal, informal, daily testing, classwork, and classroom observations guide teachers in preparing appropriate lessons.

The special education director and special education teachers promote a variety of instructional strategies for students with special needs to increase their performance level when taking a state assessment. According to the special education director, an educational environment that promotes co-teaching with a highly qualified teacher and special education teacher, helps to expose students to the regular education curriculum. Individualized classroom modifications based on each student's needs help to create more success. However, classroom modifications must be explained to regular education teachers who may not fully understand how to implement the modifications. Other examples of classroom modifications discussed in the special education teacher focus group included building up students' self esteem, writing guiding questions to help students through assignments, teaching students how to break down lengthy assignments into smaller tasks, and providing teacher notes. According to Teacher A, "Students 
should be included in deciding their modifications. When asked, students will be pretty honest with you." According to Teacher C, allowing students to help identify their modifications and resources to be successful teaches students to be their own advocate."

Students with special needs can be just as successful on state assessments as their peers without special needs. According to the special education director, success on state assessments may depend on the severity of the disability because "success looks different for every student." According to Teacher B, it depends on the student. "You can't put them in a pod because each student is different - they develop differently and they learn differently." Teacher A commented that students with special needs often freeze up because they are so insecure with themselves about not having the right test taking strategies. Teacher C added, "Students with special needs are just like everyone else but their fears and worries are magnified." Special education teachers also noted one test on one particular day may not give an accurate picture of what students actually know. Test anxiety, fear of failure, and other emotions have an impact on student performance.

There are positive aspects for students with special needs taking the same assessment as their peers without special needs. The special education director commented, "Students with special needs should have the same exposure to content as students without special needs - they need to hear the same information." In the focus group discussion, Teacher A commented, "It's all positive - they [students with special needs] feel like they are a part instead of being isolated." Teacher B added that students should be given the option of participating with their modifications. In other words, do not force students to go to a small group testing area if it makes the student feel uncomfortable. Students with special needs want to feel included. 
There are negative aspects of students with special needs taking the same assessment as their same-aged peers. Common themes from the interview and focus group discussion included stress/anxiety and fear of failure or defeat. Teacher B indicated some students feel state testing is a waste of time because they do not feel they will be successful.

Once students have taken a state assessment, students respond in a variety of ways when given results. When students do well, they are excited and it reinforces their motivation to do their best. The special education director stated it depends on how the results are given on how well students perceive their results. When test results are explained, goals are set, and encouragement is given, students may respond positively. However, if a student does not reach a desired level of achievement, a student's reaction could be a negative experience. Teacher A explained one particular student's self-esteem dropped. This student began to doubt if he really knew the information. Teacher $\mathrm{C}$ stated another student responded that he would never go to college. The student did not have the hope that college was a possibility for his future.

In order for students to be successful, individualized testing must occur. This depends on the students as some students perform well when given modifications for oral examination, others may do better with paper and pencil assessments, while others may do best with a computer-based assessment, according to the special education director. Teacher A commented students freeze up when they feel they will not score as well as others and state assessments are "a one-time snapshot and it may not be accurate that particular day. In my opinion, I don't think that everything should be based upon one test on one day." 


\section{Recommendations from Current Study}

An examination of the overall perceptions of students with special needs and special educators along with the significant difference in performance of students with special needs compared to their peers, indicated concerns with students' self-esteem, education equity, and assessment equity. Within this study, students with special needs and special educators indicated strategies that might assist in addressing those concerns. The following recommendations are made based on the role that each group represents: Special Education Teachers.

- Determine classroom modifications to meet the needs of each student with special needs with input from IEP team and student. Instruct educators on how to properly use modifications.

- Teach students to become their own advocates regarding classroom modifications by reminding regular education teachers of their classroom modifications.

- Use the same testing accommodations on a daily basis that will be used on state assessments. It is important that these modifications do not significantly alter what the test is supposed to measure or the comparability of the scores.

- Reduce text anxiety by reminding students this is only one test that will assess their knowledge, and there will be field questions asked about concepts in which they are not familiar to check for validity for the next school year (Willis, 2007). Addressing this prior to the assessment and encouraging students to do their very best could relieve testing anxiety. 
- Refer students to a Missouri Vocational Rehabilitation counselor to inquire about assistance in attending college, postsecondary training, and supported employment opportunities.

Administrators.

- Provide co-teaching classrooms in order to expose students to the regular education curriculum through co-teaching. Co-teaching results when a general education teacher and a regular education teacher share teaching responsibilities within a classroom for students with and without special needs (Wischnowski, Salmon, \& Eaton, 2004).

- Assist special education teachers in training educators on how to implement modifications.

Policy Makers.

- Use benchmark or formative assessments throughout the school year rather than a summative test at the end of the year. "No single test does everything; thus, it is important to use multiple measures and repeated measurements" (Elliott, Braden, \& White, 2001). Students must be given multiple opportunities to demonstrate proficiency (National Joint Committee on Learning Disabilities, 2004).

\section{Recommendations from Related Research}

In addition to the strategies that were given by students with special needs and special educators, additional recommendations have been identified from related research. These research-based strategies could also address concerns identified within this study: 


\section{Special Education Teachers.}

- Provide direct instruction on how to communicate effectively and a specific plan on how to engage students with disabilities in student-led conferences (Lancaster, Schumaker, \& Deshler, 2002).

- Provide more project-based activities. When students are involved in a community of learners, such as project-based projects, they tend to rise to higher levels of learning, have reduced academic anxieties, and build their confidence through positive recognition of group work (Willis, 2007).

- Personalize learning experiences. Ferlazzo (2017) identified four key elements personalized learning as: (a) autonomy by allowing students determine what they are doing and how they are doing it; (b) competence, or self-efficacy by giving students the skills needed to complete the task and encouraging a growth mindset; (c) relatedness by developing closer relationships with other classmates or the teacher; and (d) relevance by creating student perceptions that the task is of the student's self-interest.

- Mendler (2000) identified five key processes educators can use to inspire and motivate students to do their best: (a) emphasize effort by allowing students to redo assignments, separate effort from achievement when grading, encourage students to improve one thing every day, and celebrate successes; (b) create hope by showing students how achievement can benefit their lives, create challenges that can be mastered, acknowledge mistakes, set goals, and encourage and support positive affirmations; (c) respect power by involving students in developing procedures/rules/consequences, giving responsibility, listening to opinions, and 
offering choices; (d) build relationships by being open to feedback, offering genuine compliments, and showing kindness; (e) express enthusiasm by showing a love of learning, being a lifelong learner, and arousing interest. With encouragement, students may extend their learning process beyond high school. "It's about helping students find their spark and make their own fire" (Ferlazzo, 2017).

Policy Makers.

- Individualize assessments by providing alternative assessments for students with special needs regardless of the severity of their disability. Assess the same concepts and activities as same-aged peers; however, assess a little differently by (a) reducing the amount and complexity of information, (b) reducing constructirrelevant language, and/or (c) supporting students' processing of information by segmenting or chunking information or by providing graphs to support understanding (Lemons et al., 2012).

\section{Conclusion}

Test scores and measures of achievement indicate where a student is currently functioning, but do not indicate where a student could end up (Dweck, 2006). The purpose of special education is not to turn every student with special needs into a gradelevel performer, but to allow a team of individuals to decide on a plan of action to help the student lead a happy, productive, independent life once they exit the school system (Lemons et al., 2012). In order to do so, policy makers must change the way students with special needs are assessed in order to encourage them to keep progressing, no matter how long it takes. One test does not fit all. It simply gives an accountability measure for 
schools but does not take into consideration the unintentional outcome of suppressing students with special needs. Students with special needs require support and encouragement in order to be successful. Compare the scores of students with special needs on an individual basis for academic progress rather than comparing with same-aged peers. It is recommended that the policy of mandating state assessments for students with special needs be investigated and the policy implementation modified so all students can communicate their knowledge and show progress. 


\section{References}

Alegre, M. A., \& Ferrer G. (2010). School regimes and education equity: Some insights based on PISA 2006. British Educational Research Journal, 36(3), 433-461. doi: $10.1080 / 01411920902989193$

Blanken, M. J. (2012). University of Missouri Announces Innovative Scholarly Communication Initiative. Retrieved from http://munews.missouri.edu/newsreleases/2012/0716-university-of-missouri-announces-innovative-scholarlycommunication-initiative/

Bolman, L. G., \& Deal, T. E. (2008). Reframing organizations: Artistry, choice, and leadership (4th ed.). San Francisco, CA: Jossey-Bass.

Cohen, D. K., \& Moffitt, S. L. (2011). The influence of practice on policy. In D. E. Mitchell, R. L. Crowson, \& D. Y Shipps, (Eds.). Shaping education policy: Power and process (pp. 63-80). New York, NY: Routledge.

Creswell, J. W. (2013). Qualitative inquiry and research design: Choosing among five approaches (3rd ed.). Thousand Oaks, CA: Sage.

Creswell, J. W. (2014). Research design: Qualitative, quantitative, and mixed methods approaches. Thousand Oaks, CA: Sage.

Cumming, J. J., \& Dickson, E. A. (2007). Equity in assessment: Discrimination and disability issues from an Australian legal perspective. Education and the Law, 19(3/4), 201-220. doi: 10.1080/09539960701762854

Department of Elementary and Secondary Education. (2015a). IEP form 7. Retrieved from http://dese.mo.gov/specialeducation/compliance/ individualized-educationprogram-iep 
Department of Elementary and Secondary Education. (2015b). Individualized education program (IEP). Retrieved from http://dese.mo.gov/specialeducation/compliance/ individualized-education-program-iep

Department of Elementary and Secondary Education. (2015c). LEA guide to the Missouri assessment program 2014-2015. Retrieved from https://dese.mo.gov/collegecareer-readiness/assessment/lea-guide-missouri-assessment-program-2014-2015

Department of Elementary and Secondary Education. (2015d). Vision, mission, \& goals. Retrieved from http://dese.mo.gov/commissioner/vision-mission-goals Department of Elementary and Secondary Education. (2016b). Top 10 by 20. Retrieved from https://dese.mo.gov/top-10-by-20

Dweck, C. S. (2006). Mindset: The new psychology of success; How we can learn to fulfill our potential. Ballantine Books: New York.

Elliott, S. N., Braden, J.P., White, J. L. (2001). Assessing one and all; Educational accountability for students with disabilities. Council for Exceptional Children: Arlington, VA.

Ferlazzo, L. (2017). Student engagement: These four elements can spark intrinsic motivation for English language learners and others. Educational Leadership, 74(6), 28-33.

Field, A. (2013). Discovering statistics using IBM SPSS statistics (4th ed.). Thousand Oaks, CA: Sage

Fink, A. (2013). How to conduct surveys: A step-by-step guide (4th ed.). Thousand Oaks, CA: Sage.

Guest, G., MacQueen, K. M., \& Namey, E. E. (2012). Applied thematic analysis. 
Thousand Oaks, CA: Sage.

Kalyanpur, M., Harry, B., \& Skrtic, T. (2000). Equity and advocacy expectations of culturally diverse families' participation in special education. International Journal of Disability, Development and Education, 47(2), 119-136.

Kettler, R. J. (2012). Testing accommodations: Theory and research to inform practice. International Journal of Disability, Development and Education, 59(1), 53-66.

Klein, A. (2015). No child left behind: An overview. Education Week. Retrieved from http://www.edweek.org/ew/section/multimedia/no-child-left-behind-overviewdefinition-summary.html

Krueger, R. A., \& Casey M. A. (2009). Focus groups: A practical guide for applied research (4th ed.). Thousand Oaks, CA: Sage.

Lancaster, P. E., Schumaker, J. B., \& Deshler, D. D. (2002). The development and validation of an interactive hypermedia program for teaching a self-advocacy strategy to students with disabilities. Learning Disability Quarterly, 25(4), 277302.

Lemons, C. J., Kloo, A., Zigmond, N., Fulmer, D., Lupp, L. (2012). Implementing an alternate assessment based on modified academic achievement standards: When policy meets practice. International Journal of Disability, Development and Education, 59(1), 67-79.

Lyons, R. (2004). Measuring the gap: The state of equity of student achievement in Kentucky. Educational Research Quarterly, 27(3), 10-20. 
Malmgren, K. W., McLaughlin, M. J., \& Nolet, V. (2005). Accounting for the performance of students with disabilities on statewide assessments. Journal of Special Education, 39(2), 86-96.

McDavid, J. C., Huse, I., \& Hawthorn, L. R. L. (2013). Program evaluation and performance measurement: An introduction to practice (2nd ed.). Thousand Oaks, CA: Sage.

McLaughlin, M. J., Embler, S., Hernandez, G., \& Caron, E. (2005). No child left behind and students with disabilities in rural and small schools. Rural Special Education Quarterly, 24(1), 32-39.

McNeil, M. (2011). Are 82\% of schools 'failing' under NCLB, as Duncan warned? Education Week. Retrieved from http://blogs.edweek.org/edweek/campaign-k12/2011/08/are_82_of_schools_failing_unde.html

Merriam, S. B. (2009). Qualitative research: A guide to design and implementation. San Francisco, CA: Jossey-Bass.

Mendler, A. N. (2000). Motivating students who don't care: Successful techniques for educators. Solution Tree Press: Bloomington, IN.

Meyen, E. , Poggio, J., Seok, S., \& Smith, S. (2006). Equity for students with high incidence disabilities in statewide assessments: A technology-based solution. Focus on Exceptional Children, 38(7), 1-8.

Missouri Governor's Office. (1993). A primer to the outstanding schools act. Retrieved from http://files.eric.ed.gov/fulltext/ED369165.pdf

National Joint Committee on Learning Disabilities (2004). State and district-wide 
assessments and students with learning disabilities: A guide for states and school districts. Learning Disability Quarterly, 27, 67-77.

Omerod, P. (2007). Why most things fail: Evolution, extinction and economics. New York, NY: Wiley.

Skiba, R. J., Simmons, A. B., Ritter, S., Gibb, A. C., Rausch, M. K., Cuadrado, J., \& Chung, C. G. (2008). Achieving equity in special education: History, status, and current challenges. Exceptional Children, 74(3), 264-288.

U.S. Department of Education. (2016a). Every Student Succeeds Act (ESSA). Retrieved from http://www.ed.gov/essa?src=rn

Willis, J. (2007). Brain-friendly strategies for the inclusion classroom. Association for Supervision and Curriculum Development; Alexandria, VA.

Wischnowski, M. W., Salmon, S. J., \& Eaton, K. (2004). Evaluating co-teaching as a means for successful inclusion of students with disabilities in a rural district. Rural Special Education Quarterly, 23(3), 3-14.

Wyse, A. E., Dean, V. J., \& Viger, S. G. (2013). Considerations for equating alternative assessments: Two case studies of alternate assessments based on alternate achievement standards. Applied Measurement in Education, 26, 50-72. doi:

$10.1080 / 08957347.2013 .739460$ 
SECTION FIVE:

JOURNAL ARTICLE TO BE SUBMITTED TO

Rural Special Education Quarterly 
DOES ONE TEST FIT ALL? THE EFFECTS OF STATE-MANDATED

ASSESSMENTS ON STUDENTS WITH SPECIAL NEEDS

by:

Dr. Teresa Nash, EdD, University of Missouri- Columbia tnash@avabears.net

Rural Route 4 Box 1400

Ava, MO 65608

Dr. Cynthia MacGregor, EdD, University of Missouri- Columbia cmacgregor@missouristate.edu

Park Central Office Building (117 Park Central Square) 120

901 S. National Ave.

Springfield, MO 65897

Dr. Kim Finch, EdD, Missouri State University

KimFinch@MissouriState.edu

Park Central Office Building (117 Park Central Square) 115

901 S. National Ave.

Springfield, MO 65810

Dr. Tamara Arthaud, PhD, Missouri State University

TamaraArthaud@MissouriState.edu

Park Central Office Building (117 Park Central Square)

901 S. National Ave.

Springfield, MO 65810

Dr. T. C. Wall, EdD, Missouri State University

twall@bolivarschools.org

$524 \mathrm{~W}$. Madison

Bolivar, MO 65613

June, 2017 


\begin{abstract}
This mixed methods study examined the effects of requiring students with special needs to take the same assessment as their same-aged peers. A significant difference in student performance on End-of-Course (EOC) exams was found at the state and local level when comparing students with special needs to students without special needs. Students with special needs expressed concerns with not performing well on EOCs, fear of not knowing or remembering concepts assessed, and not being smart enough to go on to college. Student self-esteem, classroom modifications, and assessment procedures of students with special needs were concerning to special educators. By acknowledging that each student performs at different levels, assessing students according to each student's level of performance, and allowing students to experience success, the educational system will be leaving no child behind.
\end{abstract}


Does one test fit all? School districts across the nation are held to accountability standards based on state-mandated assessments. As part of the Missouri School Improvement Program (MSIP 5), the intention of administering state-mandated assessments is to hold public schools accountable for student progress toward the Missouri Learning Standards (Department of Elementary and Secondary Education, 2015a). The No Child Left Behind Act of 2001 reinforced the necessity for all students to take state assessments, including students with special needs, and created a universal system of accountability for public schools (Malmgren, McLaughlin, \& Nolet, 2005). However, when creating and modifying policies that mandate all students take state assessments, are we, as a society, assisting or further marginalizing students with special needs?

\section{Statement of the Problem}

Not all students perform at the same level nor do they progress academically at the same rate. Therefore, why is it a requirement that we give all students the same assessment and expect every student to perform at proficient or advanced levels? Applying a statistical measurement in which students are classified by performance using single cut scores may advantage or disadvantage particular subgroups (Wyse, Dean, \& Viger, 2013). "Principles of quality assessment indicate that a variety of assessment activities should be undertaken to inform high stakes assessments" (Cumming \& Dickson, 2007, p. 208). Although many school districts assess student progress on multiple benchmark assessments each year, state and national assessments are assessed on a single end-of-course assessment. "Schools and in some instances students are held 
accountable for achieving specified levels of performance" (McLaughlin, Embler, Hernandez, \& Caron, 2005, p. 32).

Policy makers are challenged to ensure that state assessments measure student performance and allow all students to demonstrate what they have learned (Meyen, Poggio, Seok, \& Smith, 2006). According to Cumming and Dickson (2007), "advantage or disadvantage occurs when standard assessment conditions and administration prevent students with a special learning need or disability from being able to demonstrate their learning achievement, where students without such needs or disabilities will not be so hampered" (p. 202). Depending on individual needs of students, testing accommodations are determined by a student's Individualized Education Plan team to assist the student in communicating concepts learned and off-set skill deficits (Kettler, 2012). Although testing accommodations may be granted, these adjustments do not always assist the student in communicating what is known, especially if daily classroom accommodations do not mirror accommodation options for a specific test. When this occurs, students may become confused and at a loss regarding how to approach the assessment. This could affect how the student performs on an assessment and overall accountability scores for the district. When accountability standards are not met, the focus is on the school district, not how the assessment affects the students.

\section{Purpose of the Study}

The purpose of this study was to analyze the perceptions of students with special needs and special educators regarding the requirement that all students who do not qualify for an alternative assessment take the same assessment at the same grade level, regardless of current level of performance. The focus of this study was on the 
perceptions of students and teachers and how the continuous basic and below basic achievement levels have affected students' self-esteem and outlook for future goals. Participants were students with special needs who have been identified through academic and cognitive testing to receive an Individualized Education Program (IEP) and were currently provided services as identified by an IEP team (DESE, 2015a). Aspects of education equity (Alegre \& Ferrer, 2006; Skiba et al., 2008) assessment equity (Lyons, 2004) and advocacy (Kalyanpur, Harry, \& Skrtic, 2000) will be investigated in this case study.

\section{Research Questions}

The research questions guiding this study are:

1. Is there a significant difference in the performance of students in the subgroup of IEP compared to the overall student performance on the English II and Algebra I End-of-Course assessment?

2. According to the students with special needs perceptions, what are the positive and negative aspects of requiring students with special needs to take the same state assessments as their same-aged peers?

3. According to the special educators' perceptions, what are the positive and negative aspects of requiring students with special needs to take the same state assessments as their same-aged peers?

\section{Conceptual Theoretical Framework}

This study will center on the impact of policy implementation through the political frame (Bolman \& Deal, 2008). Policies are statements of intended outcomes by the government or other agents to achieve specific outcomes (McDavid, Huse, \& 
Hawthorn, 2013). Bolman and Deal (2008) recognized that organizations design policy through "consistent goals set at the apex of authority" (p. 198). From the political perspective, goals and policies emerge from bargaining and negotiation with major interest groups. The No Child Left Behind Act of 2001 and the 2004 Individuals With Disabilities Education Improvement Act (IDEA 2004) have emphasized the importance of closing the achievement gap between students with special needs and their same-aged peers. Closing the achievement gap is essential to providing an equitable education for all students. Students learn differently or learn at varied paces that may result in the need for unequal treatment. In order to assist students with disabilities in "leveling the playing field" with same-aged peers without disabilities, testing accommodations may be implemented. Testing accommodations are designed to remove barriers presented by a disability in order to provide students with equal access to the same opportunities (Ward, 2006).

Assessment equity is a concern for government officials as well as educators. It is important to ensure that all students are given the same opportunity to exhibit their knowledge without having an advantage or disadvantage over another student. According to Cumming and Dickson (2007), "advantage or disadvantage . . occurs when standard assessment conditions and administration prevent students with a special learning need or disability from being able to demonstrate their learning achievement, where students without such needs or disabilities will not be so hampered" (p. 202). Furthermore, if a student continuously receives low scores compared to peers, perceptions of one's self or perception of ability to achieve success may diminish (Scott, Murray, Mertens, \& Dustin, 2001). 
The theory of human motivation supported by Maslow's Hierarchy of Needs was utilized to determine the impact of state-mandated assessments given to students with special needs based upon esteem needs. According to Maslow (1943/2005), most people have a desire for a high evaluation of themselves in the areas of self-respect, self-esteem, and esteem of others. These needs can be classified into two categories: (a) "the desire for strength, for achievement, for adequacy, for confidence in the face of the world, and for independence and freedom" (Maslow, 1943/2005, p. 171); and, (b) "the desire for reputation or prestige (defining it as respect or esteem from other people), recognition, attention, importance or appreciation" (Maslow, 1943/2005, p. 171). Educational organizations need to adapt policies in order to ensure that students' self-esteem, perception of ability to achieve success, and prestige are not diminished for the sake of educational accountability.

\section{Design of the Study}

The design of this case study followed a convergent parallel mixed methods procedure. According to Creswell (2014), a mixed methods approach collects, analyzes, and interprets both quantitative and qualitative data. Through the synthesis of data, a researcher can gain a more complete understanding of a marginalized group by not only analyzing close-ended (quantitative) data, but also considering open-ended (qualitative) data to gain insights from human resources (Creswell, 2013). Through the convergent parallel mixed methods design, data are collected from both quantitative and qualitative measures, analyzed separately, and then compared to see if the data confirm or disconfirm each other (Creswell, 2014). 


\section{Setting}

This study focused on a small, rural high school in southwest Missouri (450 students or less) in grades 9-12. This high school is located in a high poverty area with a free/reduced lunch percentage steadily reported at approximately $70 \%$ and enrollment has consistently decreased over the past several years (Department of Elementary and Secondary Education, 2015b).

\section{Participants}

Participants consisted of a convenience sample within a single stage sampling procedure of students in grades 9-12 who had been identified with a disability, but did not qualify for an alternative assessment. Data regarding these participants were collected between the years of 2013 through 2016. Additionally, a special education director and special education teachers served as participants and were purposefully selected from the chosen site through a convenience sample as well. Fink (2013) defined convenience sample as people who are willing to participate. These participants were chosen because of their role as key stakeholders within the setting as well as their expertise and experiences within special education. Each research question focused on different types of data and included different participants.

\section{Data Collection Tools}

Qualitative data were collected through the use of surveys of students with disabilities, an interview with the special education director, and a focus group interview of special education teachers, as shown in Table 1. The purpose of these data collection tools was to gain insights into the perceptions of the participant sample. The interview with the special education director was conducted face-to-face with a semi-structured 
interview template. When interviewing special education teachers, a focus group was used. Krueger and Casey (2009) identified a focus group as a small group of participants who interact in a facilitated interview. Discussions are relaxed and non-threatening with participants' answers building off one another (Krueger \& Casey, 2009). All interviews were recorded and transcribed in order to identify emerging themes within responses.

With the survey, quantitative data were collected to address research questions one and two. Quantitative data were assessed in a six-point Likert scale survey. Additional quantitative data collected included pre-existing data from End of Course (EOC) assessment scores in the English II EOC and Algebra I EOC from 2013-2016, as shown in Table 1. A comparison of scores was made between students with special needs and students without special needs at both the state and local levels.

In order to reduce the likelihood of bias, the investigator utilized a third party to contact potential participants. The third party proctor signed the Survey Proctor Confidentiality/Protocol/Privacy Agreement before contacting potential participants. The proctor who was neutral from the project read the recruitment script to the potential participants, along with the principal investigator's contact information for questions. Written consents, child assent forms, and parental consent forms were given to participants to take home to read and decide if they wanted to participate in the study. The third party proctor collected all signed consents, assent and parental consent forms to give to the researcher to ensure that all assent and consents were in order prior to data collection (Creswell, 2014).

The purpose of the survey was be to generalize information from a specific group of participants so inferences can be made regarding the effects of mandated assessments 
of students with special needs (Creswell, 2014). As shown in Table 1, participating students were administered an online survey. The online assessment tool was advantageous in the rapid turnaround of data collection (Creswell, 2014). Due to the sensitive nature of identifying thoughts and feelings of students with disabilities, student surveys were administered utilizing an online tool. Qualitative data were assessed within the surveys using open-ended, short answer questions.

\section{Data Analysis}

Within the participant school district, teaching positions have been absorbed whenever possible; however, the student to teacher ratio has remained steady at 13:1 (Department of Elementary and Secondary Education, 2015c). Over the past three years, the four-year and five-year graduation rates of students with special needs have been higher than the state average (2013-2015) with the majority of these students entering the workforce (Department of Elementary and Secondary Education, 2015d). In addition, students with special needs have scored lowered than their peers on state assessments between 2013-2016 (Department of Elementary and Secondary Education, 2015b).

Quantitative data within research question one were analyzed when comparing student performance scores on the English II and Algebra I EOCs through the logic model. The impact of the policy was analyzed between students with special needs and students without special needs. McDavid et al. (2013) stated the logic model assists in identifying intended results. Pre-existing data of EOC performance levels in the areas of English II and Algebra I of students with special needs and students without special needs were collected. Additionally, quantitative data were analyzed through a one sample $t$-test which is utilized when "there are two experimental conditions and different participants 
were assigned to each condition" (Field, 2013). The average student performance was used as the test value and compared to a set of scores in the subgroup of IEP.

Quantitative data through surveys were analyzed through the use of SurveyMonkey, an on-line survey tool. Responses were collected through a six-point Likert scale, ranging in responses from strongly disagree to strongly agree. Frequencies and percentages of each response was recorded and used to clarify findings. This data were used to answer research questions two and three.

Qualitative data within research questions two and three were analyzed through the use of grounded theory. According to Creswell (2014), grounded theory "is a design of inquiry from sociology in which the researcher derives a general, abstract theory of a process, action, or interaction grounded in the views of participants" (p. 14). Interviews, focus groups responses, and open-ended questions on the survey were analyzed through an open-coding method. The researcher was open to any possible themes at this point; therefore, this process was referred to as open-coding (Merriam, 2009). Since the amount of data was immense, the researcher winnowed the data in order to focus on specific themes (Guest, MacQueen, \& Namey, 2012). Creswell (2014) identified saturation when data no longer provides new insights.

\section{Limitations, Assumptions, and Design Controls}

This study had several limitations. First, because of the small sample size within one school district in southwest Missouri, generalizability was limited. Future research should focus on expansion of demographic variables and geographical locations for stronger generalizations and recommendations. 
Secondly, although the researcher has taken several precautions to reduce bias, interpretation of the findings could be shaped by the researcher's background and history. In order to reduce the likelihood of response bias from students, the third party proctor was not the researcher or a teacher participant of this study.

Lastly, the research design utilized a mixed methods study in order to gain insights within the responses from the participants. There are numerous variables that could affect the perceptions of students, parents, and faculty members and not all of them could be addressed or identified.

\section{Findings}

Research Question 1. A one sample $t$-test was conducted to compare student performance on the English II and Algebra I EOCs of students with special needs (IEP) to students without special needs (Non-IEP) at the state and local level (2013-2016).

As shown in Table 2, there was a significant difference in the scores at the state level for students with IEP $(M=191.550, S D= \pm 1.390)$ compared to students with NonIEP $(M=210.380, S D=1.802)$ conditions; $t=-12.504, p<.001$. There was a significant difference in the scores at the local level for students with IEP $(M=199.600, S D= \pm$ 4.854) compared to students with Non-IEP $(M=213.000, S D= \pm 3.869) ; t=-2.304, p=$ .030. These results suggest that students with special needs scored significantly lower than students without special needs on the English II EOC at both the state and local level for the years 2013 through 2016.

As shown in Table 3, there was a significant difference in the scores at the state level for students with IEP $(M=186.120, S D= \pm 3.071)$ and students with Non-IEP $(M=$ 206.150, $S D=1.717$ ) conditions; $t=-9.858, p<.001$. There was a significant difference 
in the scores at the local level for student with IEP $(M=189.020, S D= \pm 1.357)$ and students with Non-IEP $(M=204.350, S D= \pm 3.951)$ conditions; $t=-6.353, p<.001$. These results suggest students with special needs scored significantly lower on the Algebra I EOC than students without special needs.

Research Question 2. Qualitative data were obtained through an on-line survey to gain perceptions of students with special needs regarding the state requirement of taking state assessments. Nineteen students responded to the survey.

Students were asked about their performance on the Algebra I EOC, English II EOC, and the ACT. About 77\% of students felt good about themselves when they performed well on the Algebra I EOC. Most students indicated their scores would show them how much they had learned in the Algebra I course. About $83 \%$ of students felt good about themselves when they performed well on the English II EOC. These students felt the English II EOC results would show how much they had improved in the course and how well they could spell and write. About $84 \%$ felt good about themselves when they performed well on the ACT. Participants indicated ACT results would help them get into their college of choice or would show how well they might perform in college. When taking the EOC, about $88 \%$ of students slightly to strongly agreed they received the same accommodations for a test in the classroom as they did when taking an EOC.

Students were asked about their perceptions if they did not do well on EOCs or the ACT. About $72 \%$ of students slightly to strongly agreed the EOC does not affect how successful they would be after high school. About $70 \%$ of students indicated they slightly to strongly agreed they felt bad if they did not perform well on an EOC. About $61 \%$ of students slightly to strongly disagreed they would not be successful after high 
school if they did not perform well on the Algebra I EOC. Most students were concerned about not knowing the concepts or not performing well on the Algebra I EOC. About $67 \%$ of students slightly to strongly disagreed they would not be successful after high school if they did not perform well on the English II EOC. Participants indicated they were concerned about not remembering or knowing the concepts and fear of not scoring well. About $52 \%$ of students slightly to strongly agreed they would not be successful after high school if they did not do well on the ACT. Some concerns included not being smart enough to go on to college, stress of failing, and not being allowed to go on to college if their score was not high enough.

Postsecondary plans were addressed in the on-line survey. About $79 \%$ of the students surveyed indicated they slightly to strongly agreed they had plans to attend college, about $31 \%$ slightly to strongly agreed on plans for vocational training, about $5 \%$ slightly to strongly agreed joining the military, and about $95 \%$ had plans of getting a job after high school.

Research Question 3. Qualitative data to gain the perceptions of special educators were collected through a personal interview of the special education director and a focus group discussion of three special education teachers.

In order to make decisions to assist students in learning, each of the educators indicated they involved a team of people to assist, such as parents, the student (depending on age), regular education teachers, special education teachers, administrators, counselors, and special groups. All of these individuals assist in determining appropriate modifications to meet the needs of each student. In order to show students are making progress in academics, this team uses current level of performance to determine where 
the student is currently functioning and sets goals for student progress. Classroom modifications and testing accommodations are also determined to help the student express their knowledge.

The special education director and special education teachers promote a variety of instructional strategies for students with special needs to increase their performance level when taking a state assessment. According to the special education director, an educational environment that promotes co-teaching with a highly qualified teacher and special education teacher, helps to expose students to the regular education curriculum. Individualized classroom modifications based on each student's needs help to create more success. However, classroom modifications must be explained to regular education teachers who may not fully understand how to implement the modifications. Other examples of classroom modifications discussed in the special education teacher focus group included building up students' self esteem, writing guiding questions to help students through assignments, teaching students how to break down lengthy assignments into smaller tasks, and providing teacher notes. According to Teacher A, "Students should be included in deciding their modifications. When asked, students will be pretty honest with you." According to Teacher C, "allowing students to help identify their modifications and resources to be successful teaches students to be their own advocate." Students with special needs can be just as successful on state assessments as their peers without special needs. According to the special education director, success on state assessments may depend on the severity of the disability because "success looks different for every student." According to Teacher B, it depends on the student. "You can't put them in a pod because each student is different - they develop differently and they learn 
differently." Teacher A commented students with special needs often freeze up because they are so insecure with themselves about not having the right test taking strategies. Teacher C added, "Students with special needs are just like everyone else but their fears and worries are magnified." Special education teachers also noted one test on one particular day may not give an accurate picture of what students actually know. Test anxiety, fear of failure, and other emotions have an impact on student performance.

There are positive aspects for students with special needs taking the same assessment as their peers without special needs. The special education director commented, "Students with special needs should have the same exposure to content as students without special needs - they need to hear the same information." In the focus group discussion, Teacher A commented, "It's all positive - they [students with special needs] feel like they are a part instead of being isolated." Teacher B added students should be given the option of participating with their modifications. In other words, special educators recommend not forcing students to go to a small group testing area if it makes the student feel uncomfortable. Students with special needs want to feel included.

There are negative aspects of students with special needs taking the same assessment as their same-aged peers. Common themes from the interview and focus group discussion included stress/anxiety and fear of failure or defeat. Teacher B indicated some students feel state testing is a waste of time because they do not feel they will be successful.

Once students have taken a state assessment, students respond in a variety of ways when given results. When students do well, they are excited and it reinforces their motivation to do their best. The special education director stated that it depends on how 
the results are given on how well students perceive their results. When test results are explained, goals are set, and encouragement is given, students may respond positively. However, if a student does not reach a desired level of achievement, a student's reaction could be a negative experience. Teacher A explained one particular student's self-esteem dropped. This student began to doubt if he really knew the information. Teacher $\mathrm{C}$ stated another student responded he would never go to college. The student did not have the hope that college was a possibility for his future.

According to special educators, assessment accommodations should be considered when testing students with special needs. The accommodations depend on the student's disability as some students perform well when given modifications for oral examination, others may do better with paper and pencil assessments, while others may do best with a computer-based assessment, according to the special education director. Teacher A commented students freeze up when they feel they will not score as well as others and state assessments are "a one-time snapshot and it may not be accurate that particular day. In my opinion, I do not think everything should be based upon one test on one day."

\section{Recommendations from Current Study}

An examination of the overall perceptions of students with special needs and special educators along with the significant difference in performance of students with special needs compared to their peers, indicated concerns with students' self-esteem, education equity, and assessment equity. Within this study, students with special needs and special educators indicated strategies that might assist in addressing those concerns. The following recommendations are made based on the role that each group represents: 


\section{Special Education Teachers.}

- Determine classroom modifications to meet the needs of each student with special needs with input from IEP team and student. Instruct educators on how to properly use modifications.

- Teach students to become their own advocates regarding classroom modifications by reminding regular education teachers of their classroom modifications.

- Use the same testing accommodations on a daily basis that will be used on state assessments. It is important these modifications do not significantly alter what the test is supposed to measure or the comparability of the scores.

- Reduce text anxiety by reminding students this is only one test that will assess their knowledge and there will be field questions asked about concepts in which they are not familiar to check for validity for the next school year (Willis, 2007). Addressing this prior to the assessment and encouraging students to do their very best could relieve testing anxiety.

- Refer students to a Vocational Rehabilitation counselor to inquire about assistance in attending college, postsecondary training, supported employment opportunities, etc. through Missouri Vocational Rehabilitation.

\section{Administrators.}

- Provide co-teaching classrooms in order to expose students to the regular education curriculum through co-teaching. Co-teaching results when a general education teacher and a regular education teacher share teaching responsibilities within a classroom for students with and without special needs (Wischnowski, Salmon, \& Eaton, 2004). 
- Assist special education teachers in training educators on how to implement modifications.

\section{Policy Makers.}

- Use benchmark or formative assessments throughout the school year rather than a summative test at the end of the year. "No single test does everything; thus, it is important to use multiple measures and repeated measurements” Elliott, Braden, \& White, 2001). Students must be given multiple opportunities to demonstrate proficiency (National Joint Committee on Learning Disabilities, 2004).

\section{Recommendations from Related Research}

In addition to the strategies that were given by students with special needs and special educators, additional recommendations have been identified from related research. These research-based strategies could also address concerns identified within this study:

\section{Special Education Teachers.}

- Provide direct instruction on how to communicate effectively and a specific plan on how to engage students with disabilities in student-led conferences (Lancaster, Schumaker, and Deshler, 2002).

- Provide more project-based activities. When students are involved in a community of learners, such as project-based projects, they tend to rise to higher levels of learning, have reduced academic anxieties, and build their confidence through positive recognition of group work (Willis, 2007).

- Personalize learning experiences. Ferlazzo (2017) identified four key elements personalized learning as: (a) autonomy by allowing students determine what they 
are doing and how they are doing it; (b) competence, or self-efficacy by giving students the skills needed to complete the task and encouraging a growth mindset; (c) relatedness by developing closer relationships with other classmates or the teacher; and (d) relevance by creating student perceptions that the task is of the student's self-interest.

- Mendler (2000) identified five key processes educators can use to inspire and motivate students to do their best: (a) emphasize effort by allowing students to redo assignments, separate effort from achievement when grading, encourage students to improve one thing every day, and celebrate successes; (b) create hope by showing students how achievement can benefit their lives, create challenges that can be mastered, acknowledge mistakes, set goals, and encourage and support positive affirmations; (c) respect power by involving students in developing procedures/rules/consequences, giving responsibility, listening to opinions, and offering choices; (d) build relationships by being open to feedback, offering genuine compliments, and showing kindness; (e) express enthusiasm by showing a love of learning, being a lifelong learner, and arousing interest. With encouragement, students may extend their learning process beyond high school. "It's about helping students find their spark and make their own fire" (Ferlazzo, 2017).

Missouri Department of Elementary and Secondary Education and Other Policy Makers.

- Individualize assessments by providing alternative assessments for students with special needs regardless of the severity of their disability. Assess the same concepts and activities as same-aged peers; however, assess a little differently by 
(a) reducing the amount and complexity of information, (b) reducing constructirrelevant language, and/or (c) supporting students' processing of information by segmenting or chunking information or by providing graphs to support understanding (Lemons et al., 2012).

\section{Conclusion}

Test scores and measures of achievement indicate where a student is currently functioning, but do not indicate where a student could end up (Dweck, 2006). The purpose of special education is not to turn every student with special needs into a gradelevel performer, but to allow a team of individuals to decide on a plan of action to help the student lead a happy, productive, independent life once they exit the school system (Lemons et al., 2012). In order to do so, policy makers must change the way students with special needs are assessed in order to encourage them to keep progressing, no matter how long it takes. One test does not fit all. It simply gives an accountability measure for schools but does not take into consideration the unintentional outcome of suppressing students with special needs. Students with special needs require support and encouragement in order to be successful. Compare the scores of students with special needs on an individual basis for academic progress rather than comparing with same-aged peers. It is recommended that the policy of mandating state assessments for students with special needs be investigated and the policy implementation modified so all students can communicate their knowledge and show progress. 


\section{References}

Alegre, M. A., \& Ferrer G. (2010). School regimes and education equity: Some insights based on PISA 2006. British Educational Research Journal, 36(3), 433-461. doi: $10.1080 / 01411920902989193$

Bolman, L. G., \& Deal, T. E. (2008). Reframing organizations: Artistry, choice, and leadership (4th ed.). San Francisco, CA: Jossey-Bass.

Creswell, J. W. (2013). Qualitative inquiry and research design: Choosing among five approaches (3rd ed.). Thousand Oaks, CA: Sage.

Creswell, J. W. (2014). Research design: Qualitative, quantitative, and mixed methods approaches. Thousand Oaks, CA: Sage.

Cumming, J. J., \& Dickson, E. A. (2007). Equity in assessment: Discrimination and disability issues from an Australian legal perspective. Education and the Law, 19(3/4), 201-220. doi: 10.1080/09539960701762854

Department of Elementary and Secondary Education. (2015a). MSIP5 comprehension guide. Retrieved from https://dese.mo.gov/sites/default/files/ MSIP_5_2015_Comprehensive_Guide.pdf

Department of Elementary and Secondary Education. (2015b). District demographic data. Retrieved from http://mcds.dese.mo.gov/guidedinquiry

Department of Elementary and Secondary Education. (2015c). District student staff ratios. Retrieved from https://mcdssecured.dese.mo.gov/guidedinquiry

Department of Elementary and Secondary Education. (2015d). Special education profile report. Retrieved from https://mcdssecured.dese.mo.gov/guidedinquiry/Pages/ Special-Education.aspx 
Dweck, C. S. (2006). Mindset: The new psychology of success; How we can learn to fulfill our potential. Ballantine Books: New York.

Elliott, S. N., Braden, J.P., White, J. L. (2001). Assessing one and all; Educational accountability for students with disabilities. Council for Exceptional Children: Arlington, VA.

Ferlazzo, L. (2017). Student engagement: These four elements can spark intrinsic motivation for English language learners and others. Educational Leadership, 74(6), 28-33.

Field, A. (2013). Discovering statistics using IBM SPSS statistics (4th ed.). Thousand Oaks, CA: Sage

Fink, A. (2013). How to conduct surveys: A step-by-step guide (4th ed.). Thousand Oaks, CA: Sage.

Guest, G., MacQueen, K. M., \& Namey, E. E. (2012). Applied thematic analysis. Thousand Oaks, CA: Sage.

Individuals With Disabilities Education Improvement Act. (2004). Pub. L. No. 108-446.

Kalyanpur, M., Harry, B., \& Skrtic, T. (2000). Equity and advocacy expectations of culturally diverse families' participation in special education. International Journal of Disability, Development and Education, 47(2), 119-136.

Kettler, R. J. (2012). Testing accommodations: Theory and research to inform practice. International Journal of Disability, Development and Education, 59(1), 53-66.

Krueger, R. A., \& Casey M. A. (2009). Focus groups: A practical guide for applied research (4th ed.). Thousand Oaks, CA: Sage.

Lancaster, P. E., Schumaker, J. B., \& Deshler, D. D. (2002). The development and 
validation of an interactive hypermedia program for teaching a self-advocacy strategy to students with disabilities. Learning Disability Quarterly, 25(4), 277302.

Lemons, C. J., Kloo, A., Zigmond, N., Fulmer, D., Lupp, L. (2012). Implementing an alternate assessment based on modified academic achievement standards: When policy meets practice. International Journal of Disability, Development and Education, 59(1), 67-79.

Lyons, R. (2004). Measuring the gap: The state of equity of student achievement in Kentucky. Educational Research Quarterly, 27(3), 10-20.

Malmgren, K. W., McLaughlin, M. J., \& Nolet, V. (2005). Accounting for the performance of students with disabilities on statewide assessments. Journal of Special Education, 39(2), 86-96.

Maslow, A. H. (1943/2005). A theory of human motivation. In J. M. Shafritz, J. S. Ott, \& Y.S. Jang (Eds.), Classics of organizational theory (6th ed., pp. 167-178). Boston, MA: Wadsworth. (Reprinted from Psychological Review 50, pp. 370-396, 1943)

McDavid, J. C., Huse, I., \& Hawthorn, L. R. L. (2013). Program evaluation and performance measurement: An introduction to practice (2nd ed.). Thousand Oaks, CA: Sage.

McLaughlin, M. J., Embler, S., Hernandez, G., \& Caron, E. (2005). No child left behind and students with disabilities in rural and small schools. Rural Special Education Quarterly, 24(1), 32-39.

Merriam, S. B. (2009). Qualitative research: A guide to design and implementation. San Francisco, CA: Jossey-Bass. 
Mendler, A. N. (2000). Motivating students who don't care: Successful techniques for educators. Solution Tree Press: Bloomington, IN.

Meyen, E. , Poggio, J., Seok, S., \& Smith, S. (2006). Equity for students with high incidence disabilities in statewide assessments: A technology-based solution. Focus on Exceptional Children, 38(7), 1-8.

National Joint Committee on Learning Disabilities (2004). State and district-wide assessments and students with learning disabilities: A guide for states and school districts. Learning Disability Quarterly, 27, 67-77.

Scott, C. G., Murray, G. C., Mertens, C., \& Dustin, E. R. (2001). Student self-esteem and the school system: Perceptions and implications. The Journal of Educational Research, 89(5), 286-293.

Skiba, R. J., Simmons, A. B., Ritter, S., Gibb, A. C., Rausch, M. K., Cuadrado, J., \& Chung, C. G. (2008). Achieving equity in special education: History, status, and current challenges. Exceptional Children, 74(3), 264-288.

Ward, W. C. (2006). Common testing accommodations and modifications for students with disabilities. Retrieved from https://www.superduperinc.com/handouts/pdf/ 109_testing_accommodations_modifications.pdf

Willis, J. (2007). Brain-friendly strategies for the inclusion classroom. Association for Supervision and Curriculum Development; Alexandria, VA.

Wischnowski, M. W., Salmon, S. J., \& Eaton, K. (2004). Evaluating co-teaching as a means for successful inclusion of students with disabilities in a rural district. Rural Special Education Quarterly, 23(3), 3-14.

Wyse, A. E., Dean, V. J., \& Viger, S. G. (2013). Considerations for equating alternative 
assessments: Two case studies of alternate assessments based on alternate achievement standards. Applied Measurement in Education, 26, 50-72. doi: $10.1080 / 08957347.2013 .739460$ 
SECTION SIX:

A SCHOLARLY PRACTIONER REFLECTION 


\section{Dissertation Influence as an Educational Leader}

Experiences throughout a journey can teach a person many aspects of themselves. "Leadership is a process whereby an individual influences a group of individuals to achieve a common goal" (Northhouse, 2013, p. 5). Having a background of five years in special education and thirteen years as an administrator, I have always been concerned with the students who "fall through the cracks." When I look at students with special needs who are performing below grade level and have to take an assessment that could effect if they go on to college or decrease their self-esteem, I believe that we, as a society, are doing a disservice or could be suppressing students based on classroom and assessment practices. However, I recognize that with my background and my passion for educating students with special needs, I need to take a step back and not only look at the data, but also think about student perceptions regarding the state assessment. What I believe to be a disservice or suppression, may not be how students or other educators felt about students with special needs taking the same state assessments as their same-aged peers. Therefore, I wanted to conduct a study to see if there were data that supported this topic and if so, how could I, as an educational leader, help to make a difference.

Looking through the political lens, I felt it was important to know and for others to know the basic structure of the educational system, both at the state and federal levels. Although I knew the basic structure, it was interesting to see the departments at these levels were divided into various offices and the services that each offered. This is when I realized I was going to have to influence at the state level before I could make a difference locally. At the federal level, there are already states that have modified assessments for students with special needs. The same concepts were taught, but they 
were presented in a way that assisted students in communicating their knowledge. This would be ideal for Missouri; however, it is going to be important to involve the right people in order to influence change.

According to the results of my study, it is apparent there is a statistical difference in the performance of students with special needs and students without special needs. Not only does the pre-existing data from data from the Department of Elementary and Secondary education support this, but so do the perceptions of students with special needs and special educators within my participant sample. Through my study, I have identified key players at the state level with whom I will share my findings, have discussions, and hopefully bring about a change with the state assessment policy. I will also be submitting a journal article to Rural Special Education Quarterly. Hopefully, special interest groups and parents will read the findings of this study and help to influence policy makers also.

This study has ignited a passion within me to bring about change for students with special needs. My efforts will not stop with my plans to disseminate my findings and write an article. If my efforts do not make a difference with this mode of communication, I will continue to revise my plan of communication and action until I am heard. Maxwell (2006) stated the more influence you have, the more leadership potential you possess and more ability for others to work with you to achieve your dreams.

\section{Dissertation Influence as a Scholar}

"Lifelong learner" is a term heard many times in the world of education. The need to find new information and gain more knowledge occurs on a daily basis. Learning how to communicate with others, finding best practices within organizations, and 
building organizations requires one to continue to learn in order to become an effective and efficient leader.

As a scholar, I have always considered myself to be inquisitive and wanting to learn and collect new information. "At the heart of adult learning is engaging in, reflecting upon, and making meaning of our experiences, whether these experiences are primarily physical, emotional, cognitive, social, or spiritual” (Merriam \& Bierema, 2014, p. 104). As I strived to gain new information for my dissertation, I have collected and archived journal articles, books, quotations, and facts, because I know that this information will be useful not only within my dissertation, but also as a practitioner. Learning new information takes time as I like to read, savor, and process new information. One of the best ways I have found that facilitates my own processing of information is by collaborating with others and listening to various perspectives through the process of collecting data for my dissertation or through the collaborative efforts of my dissertation team.

As I near the end of my journey of my dissertation, I am very grateful for the experiences I have received. The discussions and learning experiences have been invaluable. I reflect on the rigor of the new dissertation process in comparison to other programs in which some of my colleagues are participating and there simply is no comparison. I feel very fortunate to have worked with such talented, scholarly professors who have encouraged and challenged me both as a scholar and practitioner. Thank you for a wonderful experience! 


\section{References}

Albus, D., Lazarus, S. S., \& Thurlow, M. L. (2015). 2012-13 publicly reported assessment results for students with disabilities and ELLs with disabilities (Technical Report 70). Minneapolis, MN: University of Minnesota, National Center on Educational Outcomes.

Alegre, M. A., \& Ferrer G. (2010). School regimes and education equity: Some insights based on PISA 2006. British Educational Research Journal, 36(3), 433-461. doi: $10.1080 / 01411920902989193$

American Educational Research Association. (2011). Code of ethics. Educational Researcher, 40(3), 145-146. doi: 10.3102/0013189X11410403

Armor, D. L., \& Pesier, B. A. (1998). Interdistrict choice in Massachusetts. In P. E. Peterson \& B. C. Hassel (Eds.). Learning from school choice (pp. 157-186). Washington, DC: Brookings Institutional Press.

Banaji, M. R., Bazerman, M. H., \& Chugh, D. (2003/2013). How (un)ethical are you? In HBR's 10 must reads on making smart decisions (pp. 115-131). Boston, MA: Harvard Business Review Press (Reprint R0312D).

Bardach, E. (2012). A practical guide for policy analysis: The eightfold path to more effective problem solving (4th ed.). Thousand Oaks, CA: Sage.

Bennett, G., \& Jessani, N. (2011). The knowledge translation toolkit; Bridging the knowdo gap, a resource for researchers. Thousand Oaks, CA: Sage.

Berne, R., \& Stiefel, L. (1984). The measurement of equity in school finance: Conceptual, methodological, and empirical dimensions. Baltimore, MD: Johns Hopkins University Press. 
Blanken, M. J. (2012). University of Missouri Announces Innovative Scholarly

Communication Initiative. Retrieved from http://munews.missouri.edu/newsreleases/2012/0716-university-of-missouri-announces-innovative-scholarlycommunication-initiative/

Bolman, L. G., \& Deal, T. E. (2008). Reframing organizations: Artistry, choice, and leadership (4th ed.). San Francisco, CA: Jossey-Bass.

Bowen, S. K., \& Rude, H. A. (2006). Assessment and students with disabilities: Issues and challenges with educational reform. Rural Special Education Quarterly, 25(3), 24-30.

Brown, C. A., \& Cooper, B. S. (2011). Education equity policy since 1950. In D. E. Mitchell, R. L. Crowson, \& D. Y Shipps, (Eds.). Shaping education policy: Power and process (pp. 143-163). New York, NY: Routledge.

Cohen, D. K., \& Moffitt, S. L. (2011). The influence of practice on policy. In D. E. Mitchell, R. L. Crowson, \& D. Y Shipps, (Eds.). Shaping education policy: Power and process (pp. 63-80). New York, NY: Routledge.

Collins, B. C., Hawkins, S., Keramidas, C. G., McLaren, E. M., Schuster, J. W., Slevin, B. N., \& Spoelker, D. L. (2005). The effect of no child left behind on rural students with low incidence disabilities. Rural Special Education Quarterly, 24(1), 48-53.

Cox, M. L., Herner, J. G., Demczyk M. J., \& Nieberding, J. J. (2006). Provision of testing accommodations for students with disabilities on statewide assessments: Statistical links with participation and discipline rates. Remedial and Special Education, 27(6), 346-354. 
Creswell, J. W. (2013). Qualitative inquiry and research design: Choosing among five approaches (3rd ed.). Thousand Oaks, CA: Sage.

Creswell, J. W. (2014). Research design: Qualitative, quantitative, and mixed methods approaches. Thousand Oaks, CA: Sage.

Cumming, J. J., \& Dickson, E. A. (2007). Equity in assessment: Discrimination and disability issues from an Australian legal perspective. Education and the Law, 19(3/4), 201-220. doi: 10.1080/09539960701762854

Darrow, A. A. (2007). Adaptations in the classroom: Accommodations and modification. General Music Today, 20(3), 32-34.

Department of Elementary and Secondary Education (2013). Missouri alternate assessment decision making checklist. Retrieved from https://dese.mo.gov/sites/ default/files/int

Department of Elementary and Secondary Education. (2014). IEP Form F. Retrieved from http://dese.mo.gov/special-education/compliance/individualized-educationprogram-iep

Department of Elementary and Secondary Education. (2015a). IEP form 7. Retrieved from http://dese.mo.gov/specialeducation/compliance/ individualized-educationprogram-iep

Department of Elementary and Secondary Education. (2015b). Individualized education program (IEP). Retrieved from http://dese.mo.gov/specialeducation/compliance/ individualized-education-program-iep

Department of Elementary and Secondary Education. (2015c). LEA guide to the Missouri 
assessment program 2014-2015. Retrieved from https://dese.mo.gov/collegecareer-readiness/assessment/lea-guide-missouri-assessment-program-2014-2015 Department of Elementary and Secondary Education. (2015d). Vision, mission, \& goals. Retrieved from http://dese.mo.gov/commissioner/vision-mission-goals Department of Elementary and Secondary Education. (2015e). Special education profile report. Retrieved from https://mcdssecured.dese.mo.gov/guidedinquiry/Pages/ Special-Education.aspx

Department of Elementary and Secondary Education. (2015f). District demographic data. Retrieved from http://mcds.dese.mo.gov/guidedinquiry

Department of Elementary and Secondary Education. (2015g). District student staff ratios. Retrieved from https://mcdssecured.dese.mo.gov/guidedinquiry Department of Elementary and Secondary Education. (2015h). IEP Form 9. Retrieved from http://dese.mo.gov/special-education/compliance/individualized-educationprogram-iep

Department of Elementary and Secondary Education. (2015i). Missouri Accommodations Manual. Retrieved from http://dese.mo.gov/sites/default/files/ accommodationsmanualpowerpoint.pdf

Department of Elementary and Secondary Education. (2015j). LEA guide to the Missouri assessment program 2015-2016. Retrieved from https://dese.mo.gov/collegecareer-readiness/assessment/lea-guide-missouri-assessment-program-2015-2016

Department of Elementary and Secondary Education. (2015k). MSIP5 comprehension guide. Retrieved from https://dese.mo.gov/sites/default/files/ MSIP_5_2015_Comprehensive_Guide.pdf 
Department of Elementary and Secondary Education. (2016a). Department Offices.

Retrieved from http://dese.mo.gov/department-offices

Department of Elementary and Secondary Education. (2016b). Top 10 by 20. Retrieved from https://dese.mo.gov/top-10-by-20

Department of Elementary and Secondary Education. (2016c). Advisory Panels.

Retrieved from https://dese.mo.gov/special-education/advisory-panels

Department of Elementary and Secondary Education. (2016d). Membership \&

Membership Appointment. Retrieved from https://dese.mo.gov/special education/ advisory-panels/seap/membership-membership-appointment

Department of Elementary and Secondary Education. (2016e). Meetings. Retrieved from https://dese.mo.gov/special-education/advisory-panels/seap/meetings

Department of Elementary and Secondary Education. (2016f). Governmental Affairs.

Retrieved from https://dese.mo.gov/governmental-affairs

Dweck, C. (2006). Mindset: The new psychology of success. New York, NY: Ballantine Books.

Elliott, S. N., Braden, J. P., \& White, J. L. (2001). Assessing one and all: Educational accountability for students with disabilities. Arlington, VA: Council for Exceptional Children.

Field, A. (2013). Discovering statistics using IBM SPSS statistics (4th ed.). Thousand Oaks, CA: Sage.

Fink, A. (2013). How to conduct surveys: A step-by-step guide (4th ed.). Thousand Oaks, CA: Sage.

Fletcher, D. (2009). Standardized Testing. Retrieved from http://content.time.com/time/ 
nation/ article/0,8599,1947019,00.html

Fowler, F. C. (2008). Policy studies for educational leaders: An introduction (3rd ed.). Upper Saddle River, NJ: Prentice Hall.

Fuchs, L. S., Fuchs, D., Eaton, S. B., Hamlett, C. L., \& Karns, K. M. (2000). Supplementing teacher judgments of mathematics test accommodations with objective data sources. School Psychology Review, 29(1), 65-85.

Fuhrman, S. H. (1993). The politics of coherence. In S. H. Fuhrman (Ed.), Designing coherent education policy (pp. 1-34). San Francisco, CA: Jossey-Bass.

Gardner, W. L., Avolio, B. J., Luthans, F., May, D. R., \& Walumbwa, F. O. (2005). Can you see the real me? A self-based model of authentic leader and follower development. Leadership Quarterly, 16, 343-372.

George, B. (2003). Authentic leadership: Rediscovering the secrets to creating lasting value. San Francisco, CA: Jossey-Bass.

George, B., Sims, P., McLean, A. N., \& Mayer, D. (2007/2011). Discovering your authentic leadership. In HBR's 10 must reads on leadership (pp. 163-177). Boston, MA: Harvard Business Review Press (Reprint R0702H).

Goffee, R. \& Jones, G. (2000/2011). Why should anyone be led by you? In $H B$ R's 10 must reads on leadership (pp. 79-95). Boston, MA: Harvard Business Review Press (Reprint R00506).

Goleman, D. (1996). What makes a leader? In HBR's 10 must reads on leadership (pp. 1-21). Boston, MA: Harvard Business Review Press (Reprint R0401H).

Gordon, V. N., \& Steele, G. E. (2015). The undecided college student: An academic and career advising challenge (4th ed.). Springfield, IL: Charles C Thomas. 
Guest, G., MacQueen, K. M., \& Namey, E. E. (2012). Applied thematic analysis. Thousand Oaks, CA: Sage.

Hanushek, E. A., \& Raymond, M. E. (2001). The confusing world of educational accountability. National Tax Journal, 54(2), 365-385.

Harris, D. N. \& Witte, J. F. (2011). The market for schooling. In D. E. Mitchell, R. L. Crowson, \& D. Y Shipps, (Eds.). Shaping education policy: Power and process (pp. 92-118). New York, NY: Routledge.

Hollenbeck, K. (2002). Determining when test alterations are valid accommodations or modifications for large-scale assessment. In G. Tindal \& T. Haladyna (Eds.), Large scale assessment programs for all students (pp. 109-148). Mahwah, NJ: Lawrence Erlbaum Associates.

Individuals With Disabilities Education Improvement Act. (2004). Pub. L. No. 108-446. Institute on Disability. (2016). Annual disability statistics compendium. Retrieved from http://disabilitycompendium.org/statistics/special-education

Kalyanpur, M., Harry, B., \& Skrtic, T. (2000). Equity and advocacy expectations of culturally diverse families' participation in special education. International Journal of Disability, Development and Education, 47(2), 119-136.

Kernis, M. H. (2003). Toward a conceptualization of optimal self-esteem. Psychological Inquiry, 14, 1-26.

Kettler, R. J. (2012). Testing accommodations: Theory and research to inform practice. International Journal of Disability, Development and Education, 59(1), 53-66. 
Klein, A. (2015). No child left behind: An overview. Education Week. Retrieved from http://www.edweek.org/ew/section/multimedia/no-child-left-behind-overviewdefinition-summary.html

Kossar, K., Mitchem, K., \& Ludlow, B. (2005). No child left behind: A national study of its impact on special education in rural schools. Rural Special Education Quarterly 24(1), 3-8.

Kotter, J. P. (1982). The general managers. New York, NY: Free Press.

Kotter, J. P. (1988). The leadership factor. New York, NY: Free Press.

Kotter, J. P. (2008). Power and influence: Beyond formal authority. New York, NY: Free Press.

Krueger, R. A., \& Casey M. A. (2009). Focus groups: A practical guide for applied research (4th ed.). Thousand Oaks, CA: Sage.

Kurz, A., Talapatra, D., \& Roach, A. T. (2012). Meeting the curricular challenges of inclusive assessment: The role of alignment, opportunity to learn, and student engagement. International Journal of Disability, Development and Education, $59(1), 37-52$.

Langenfeld, K., Thurlow, M., \& Scott, D. (1997). High stakes testing for students:

Unanswered questions and implications for students with disabilities. Retrieved from https://nceo.info/Resources/publications/onlinepubs/archive/

Synthesis/Synthesis26.htm

Lee, J. (2012). Educational equity and adequacy for disadvantaged minority students: 
School and teacher resource gaps toward national mathematics proficiency standard. The Journal of Educational Research, 105, 64-75. doi:

$10.1080 / 00220671.2010 .519409$

Levi, D. (2014). Group dynamics for teams (4th ed.). Thousand Oaks, CA: Sage.

Library of Congress. (2015). S.210 - An act to establish a Department of Education, and for other purposes. Retrieved from https://www.congress.gov/bill/96thcongress/senate-bill/210

Lyons, R. (2004). Measuring the gap: The state of equity of student achievement in Kentucky. Educational Research Quarterly, 27(3), 10-20.

Malen, B. (2011). An enduring issue: The relationship between political democracy and educational effectiveness. In D. E. Mitchell, R. L. Crowson, \& D. Y Shipps, (Eds.). Shaping education policy: Power and process (pp. 23-60). New York, NY: Routledge.

Malmgren, K. W., McLaughlin, M. J., \& Nolet, V. (2005). Accounting for the performance of students with disabilities on statewide assessments. Journal of Special Education, 39(2), 86-96.

Margolis, H., \& McCabe, P. P. (2004). Self efficacy: A key to improving the motivation of struggling learners. The Clearing House, 77(6), 241-249.

Maslow, A. H. (1943/2005). A theory of human motivation. In J. M. Shafritz, J. S. Ott, \& Y.S. Jang (Eds.), Classics of organizational theory (6th ed., pp. 167-178). Boston, MA: Wadsworth. (Reprinted from Psychological Review 50, pp. 370-396, 1943)

Maxwell, J. C. (2006). Your road map for success. Nashville, TN: Nelson Business.

McDavid, J. C., Huse, I., \& Hawthorn, L. R. L. (2013). Program evaluation and 
performance measurement: An introduction to practice (2nd ed.). Thousand Oaks, CA: Sage.

McDonnell, L. M., McLaughlin, M. J., \& Morrison, P. (1997). Educating one and all:

Students with disabilities and standards-based reform. Washington, DC: National Academy Press.

McKevitt, B. C., \& Elliott, S. N. (2003). Effects and perceived consequences of using read-aloud and teacher recommended testing accommodations on a reading achievement test. School Psychology Review, 32(4), 583-600.

McLaughlin, M. J. (2010). Evolving interpretations of educational equity and students with disabilities. Exceptional Children, 76(3), 265-378.

McLaughlin, M. J., Embler, S., Hernandez, G., \& Caron, E. (2005). No child left behind and students with disabilities in rural and small schools. Rural Special Education Quarterly, 24(1), 32-39.

McNeil, M. (2011). Are 82\% of schools 'failing' under NCLB, as Duncan warned? Education Week. Retrieved from http://blogs.edweek.org/edweek/campaign-k12/2011/08/are_82_of_schools_failing_unde.html

Merriam, S. B. (2009). Qualitative research: A guide to design and implementation. San Francisco, CA: Jossey-Bass.

Merriam, S. B., \& Bierema, L. L. (2014). Adult learning: Linking theory and practice. San Francisco, CA: Jossey-Bass.

Meyen, E. , Poggio, J., Seok, S., \& Smith, S. (2006). Equity for students with high incidence disabilities in statewide assessments: A technology-based solution. Focus on Exceptional Children, 38(7), 1-8. 
Missouri Governor's Office. (1993). A primer to the outstanding schools act. Retrieved from http://files.eric.ed.gov/fulltext/ED369165.pdf

Missouri School Board Association. (2000). Policy BBA: School board powers and duties. Retrieved from https://eboard.eboardsolutions.com/ePolicy/ policy.aspx $P \mathrm{PC}=\mathrm{BBA} \& \mathrm{Sch}=148 \& \mathrm{~S}=148 \& \mathrm{RevNo}=1.01 \& \mathrm{C}=\mathrm{B} \& \mathrm{Z}=\mathrm{P}$

Mitchell, D. E. (2011). The surprising history of education policy 1950 to 2010. In D. E. Mitchell, R. L. Crowson, \& D. Y Shipps, (Eds.). Shaping education policy: Power and process (pp. 3-22). New York, NY: Routledge.

National Center on Educational Outcomes. (2007). Annual performance reports state summaries: 2006-2007. Retrieved from http://data.nceo.info/index.asp

Northouse, P. G. (2013). Leadership: Theory and practice (6th ed.). Thousand Oaks, CA: Sage.

Nygaard, C., Holtham, C., \& Courtney, N. (2009). Learning outcomes - Politics, religion, or improvement? In J. Cowan (Ed.), Improving students’ learning outcomes (pp. 17-32). Portland, OR: Copenhagen Business School Press.

Omerod, P. (2007). Why most things fail: Evolution, extinction and economics. New York, NY: Wiley.

O’Neill, O. (1976). Opportunities, equalities and education. Theory and Decision, 7, 275295.

Ranbom, S. (1983). Missouri will require students to pass skills test for graduation. Retrieved from http:/www.edweek.org/ew/articles/1983/11/09/ 04100022.h03.html

Rogers, P., \& Blenko, M. (2006/2013). Who has the D? How clear decision roles 
enhance organizational performance. In HBR's 10 must reads on making smart decisions (pp. 95-113). Boston, MA: Harvard Business Review Press (Reprint R0601D).

Rural Special Education Quarterly. (2016). Rural special education quarterly guidelines for prospective authors. Retrieved from http://acres-sped.org/r/download/141607

Scott, C. G., Murray, G. C., Mertens, C., \& Dustin, E. R. (2001). Student self-esteem and the school system: Perceptions and implications. The Journal of Educational Research, 89(5), 286-293.

Shaftel, J., Xiangdon, Y., Glasnapp, D., \& Poggio, J. (2005). Improving assessment validity for students with disabilities in large-scale assessment programs. Educational Assessment, 10(4), 357-375.doi: 10.1207/s15326977ea1004_3

Shavelson, R. J., Linn, R. L., Baker, E. L., Ladd, H. F., Darling-Hammond, L., Shepard, L. A., Barton, P. E., Haertel, E., Ravitch, D., \& Rothstein, R. (2015). Problems with the use of student test scores to evaluate teachers. Retrieved from http://www.epi.org/publication/bp278/

Skiba, R. J., Simmons, A. B., Ritter, S., Gibb, A. C., Rausch, M. K., Cuadrado, J., \& Chung, C. G. (2008). Achieving equity in special education: History, status, and current challenges. Exceptional Children, 74(3), 264-288.

Skrla, L., Scheurich, J. J., Garcia, J., \& Nolly, G. (2004). Equity audits: A practical leadership tool for developing equitable and excellent schools. Educational Administration Quarterly, 40(1), 133-161. doi:10.1177/0013161X03259148

Smith, E., \& Gorard, S. (2006). Pupils' views on equity in schools. Compare, 36(1), 4156. 
Stone, D. (2002). Policy paradox. New York, NY: W. W. Norton \& Company.

Strauss, V. (2014). 13 ways high-stakes standardized tests hurt students. Retrieved from https://www.washingtonpost.com/news/answer-sheet/wp/2014/03/10/13-wayshigh-stakes-standardized-tests-hurt-students/

Thompson, L. (2004). Making the team; A guide for managers (2nd ed.). Upper Saddle River, NJ: Pearson.

U.S. Department of Education (2005). Education in the United States: A brief overview. Retrieved from https://www2.ed.gov/about/offices/list/ous/international/ edus/overview.doc

U.S. Department of Education. (2010a). About ED: An Overview of the U.S. Department of Education. Retrieved from http://www2.ed.gov/print/about/overview/ focus/what.html

U.S. Department of Education. (2010b). Thirty-five year of progress in educating children with disabilities through IDEA. Retrieved from https://www2.ed.gov/ about/offices/list/osers/idea35/history/idea-35-history.pdf

U.S. Department of Education. (2016a). Every Student Succeeds Act (ESSA). Retrieved from http://www.ed.gov/essa?src=rn

U.S. Department of Education. (2016b). Statewide and districtwide assessments. Retrieved from http://idea.ed.gov/explore/view/p/,root,dynamic,TopicalBrief,19

Valenzuela, J. S., Copeland, S. R., Huaqing Qi, C., \& Park, M. (2006). Examining educational equity: Revisiting the disproportionate representation of minority students in special education. Council for Exceptional Children, 72(4), 425-441.

Walumbwa, F. O., Avolio, B. J., Gardner, W. L., Wernsing, T. S., \& Peterson, S. J. 
(2008). Authentic leadership: Development and validation of a theory-based measure. Journal of Management, 31(1), 89-126.

Ward, W. C. (2006). Common testing accommodations and modifications for students with disabilities. Retrieved from https://www.superduperinc.com/handouts/pdf/ 109_testing_accommodations_modifications.pdf

Wyse, A. E., Dean, V. J., \& Viger, S. G. (2013). Considerations for equating alternative assessments: Two case studies of alternate assessments based on alternate achievement standards. Applied Measurement in Education, 26, 50-72. doi:

$10.1080 / 08957347.2013 .739460$

Yell, M. L., \& Katsiyannis, A. (2010). Functional behavioral assessment and IDEA '97: Legal and practice considerations. Preventing School Failure: Alternative Education for Children and Youth, 44(4), 158-162. doi: 10.1080/ 10459880009599800

Zisimopoulos, D. A., \& Galanaki, E. P. (2009). Academic intrinsic motivation and perceived academic competence in Greek elementary students with and without learning disabilities. Learning Disabilities Research \& Practice, 24(1). 33-43. 
APPENDIX 


\section{Appendix A}

\section{One Test Fits All -- Student Survey}

\begin{tabular}{|c|c|c|c|c|c|c|}
\hline $\begin{array}{l}\text { Pick one answer for each } \\
\text { question. }\end{array}$ & $\begin{array}{l}\text { Strongly } \\
\text { Disagree }\end{array}$ & Disagree & $\begin{array}{l}\text { Slightly } \\
\text { Disagree }\end{array}$ & $\begin{array}{l}\text { Slightly } \\
\text { Agree }\end{array}$ & Agree & $\begin{array}{l}\text { Strongly } \\
\text { Agree }\end{array}$ \\
\hline \multicolumn{7}{|l|}{ Question } \\
\hline \multicolumn{7}{|l|}{$\begin{array}{l}\text { 1. I receive classroom } \\
\text { modifications to assist } \\
\text { with my daily class } \\
\text { work. }\end{array}$} \\
\hline \multicolumn{7}{|l|}{$\begin{array}{l}\text { 2. When taking a test, I } \\
\text { receive special } \\
\text { accommodations (e.g., } \\
\text { go to another classroom, } \\
\text { have test read, extended } \\
\text { time, etc.) }\end{array}$} \\
\hline \multicolumn{7}{|l|}{$\begin{array}{l}\text { 3. I will take or have } \\
\text { taken an End of Course } \\
\text { Exam (EOC). }\end{array}$} \\
\hline \multicolumn{7}{|l|}{$\begin{array}{l}\text { 4. I feel like I score as } \\
\text { well as or better than } \\
\text { other students on EOCs. }\end{array}$} \\
\hline \multicolumn{7}{|l|}{$\begin{array}{l}\text { 5. I am recognized in an } \\
\text { assembly or get a reward } \\
\text { for doing well on EOCs. }\end{array}$} \\
\hline \multicolumn{7}{|l|}{$\begin{array}{l}\text { 6. I feel good about } \\
\text { myself when I do well } \\
\text { on the Algebra I EOC. }\end{array}$} \\
\hline \multicolumn{7}{|l|}{$\begin{array}{l}\text { 7. I feel good about } \\
\text { myself when I do well } \\
\text { on the English II EOC. }\end{array}$} \\
\hline \multicolumn{7}{|l|}{$\begin{array}{l}\text { 8. I feel good about } \\
\text { myself when I do well } \\
\text { on the ACT. }\end{array}$} \\
\hline \multicolumn{7}{|l|}{$\begin{array}{l}\text { 9. I receive the same } \\
\text { accommodations for a } \\
\text { test in the classroom as I } \\
\text { do when taking an EOC. }\end{array}$} \\
\hline \multicolumn{7}{|l|}{$\begin{array}{l}\text { 10. If I do not do well } \\
\text { on an EOC, I feel bad. }\end{array}$} \\
\hline \multicolumn{7}{|l|}{$\begin{array}{l}\text { 11. If I do not do well } \\
\text { on the Algebra I EOC, I } \\
\text { feel like I will not be } \\
\text { successful after high } \\
\text { school. }\end{array}$} \\
\hline \multicolumn{7}{|l|}{$\begin{array}{l}\text { 12. If I do not do well } \\
\text { on the English II EOC, I } \\
\text { feel like I will not be } \\
\text { successful after high } \\
\text { school. }\end{array}$} \\
\hline \multicolumn{7}{|l|}{$\begin{array}{l}\text { 13. If I do not do well } \\
\text { on the ACT, I feel like I } \\
\text { will not be successful } \\
\text { after high school. }\end{array}$} \\
\hline $\begin{array}{l}\text { 14. My score on an } \\
\text { EOC does not affect how }\end{array}$ & & & & & & \\
\hline
\end{tabular}




\begin{tabular}{|l|l|l|l|l|l|l|}
\hline $\begin{array}{l}\text { successful I will be after } \\
\text { high school. }\end{array}$ & & & & & & \\
\hline $\begin{array}{l}\text { 15. I feel like my } \\
\text { teachers prepare me to } \\
\text { do well on EOCs. }\end{array}$ & & & & & & \\
\hline $\begin{array}{l}\text { 16. After high school, I } \\
\text { plan on going to college. }\end{array}$ & & & & & & \\
\hline $\begin{array}{l}\text { 17. After high school, I } \\
\text { plan on going to } \\
\text { vocational training. }\end{array}$ & & & & & & \\
\hline $\begin{array}{l}\text { 18. After high school, I } \\
\text { plan on going to the } \\
\text { military. }\end{array}$ & & & & & & \\
\hline $\begin{array}{l}\text { 19. After high school, I } \\
\text { plan on getting a job. }\end{array}$ & & & & & & \\
\hline
\end{tabular}

20. What might be some benefits for you to take the Algebra I EOC?

21. What might be some benefits for you to take the English II EOC?

22. What might be some benefits for you to take the ACT?

23. What might be some problems for you to take the Algebra I EOC?

24. What might be some problems for you to take the English II EOC?

25. What might be some problems for you to take the ACT? 
Appendix B

\section{Focus Group Questions for Special Education Teachers}

Opening: $\quad$ 1. Tell me a little about yourself and your roles in this school district.

Introductory: $\quad 2$. Why did you decide to become an educator for students with special needs?

Transition: $\quad 3$. What is most rewarding when working with students with special needs?

Key Questions: 4. How do you know when students who have special needs are making progress in academics?

5. How might you assist students who have special needs to increase their performance level when taking a state assessment?

6. Overall, do you feel that students with special needs are just as successful on state assessments as their peers who do not have special needs? Why or Why not?

7. What might be some positive aspects of students with special needs taking the same assessment as their same-aged peers who do not have special needs?

8. What might be some negative aspects of students with special needs taking the same assessment as their same-aged peers who do not have special needs?

9. In your professional experiences, how do students with special needs respond when given testing results?

10. In your personal opinion, what might be some ways students with special needs to be assessed in order to demonstrate their knowledge?

11. How do you feel about students with special needs taking the ACT? What impact might this have?

Ending Question: 12. The purpose of this study is to increase awareness of the positive and negative aspects of assessing the knowledge of students with special needs by administering the same test given to their same-aged peers without special needs. Is there anything that you would like to add? 
Appendix C

\section{Interview Questions for Special Education Director}

Opening:

Transition:

Key Questions:
Introductory:

1. Tell me a little about yourself and your role in this school district.

2. Why did you decide to become a Director of Special Services?

3. What is most rewarding when working with students with special needs?

4. Who do you involve when making educational decisions regarding students with special needs?

5. How do you know when students who have special needs are making progress in academics?

6. How might you assist students who have special needs to increase their performance level when taking a state assessment?

7. Overall, do you feel that students with special needs are just as successful on state assessments as their peers who do not have special needs? Why or Why not?

8. What might be some positive aspects of students with special needs taking the same assessment as their same-aged peers who do not have special needs?

9. What might be some negative aspects of students with special needs taking the same assessment as their same-aged peers who do not have special needs?

10. In your professional experiences, how do students with special needs respond when given testing results?

11. In your personal opinion, how should students with special needs be assessed in order to demonstrate their knowledge?

Ending Question: 12 . The purpose of this study is to increase awareness of the positive and negative aspects of assessing the knowledge of students with special needs by administering the same test given to their same-aged peers without special needs. Is there anything that you would like to add? 


\title{
Appendix D
}

\section{Informed Consent For Participation in Research Activities Form}

\author{
Does One Test Fit All? The Effects of State-Mandated Assessments on Students \\ With Special Needs
}

You are invited to participate in a research study conducted by Teresa Nash under the guidance of Dr. Cynthia MacGregor through University of Missouri-Columbia. The purpose of this research is to examine the perceptions of high school students with special needs, high school special education teachers, and high school special education directors to assess and establish whether there are significant differences between the performance level of students with special needs compared to students without special needs on statemandated assessments in southwest Missouri. My research will provide information to schools, practitioners, and policy makers regarding the use and effects of state-mandated assessments for all students at the secondary level. The sample of this research will include students with special needs, high school special education teachers, and special education directors.

Your participation in this study will involve answering questions regarding your perception of how state-mandated assessments affects students with special needs through a survey, focus group discussion, or interview. Depending on the process chosen for your sample group, the time involved could be 30 to 60 minutes. This process will occur at one research site.

There are no anticipated risks associated with this research. There are no direct benefits for you participating in this study. However, your participation will contribute to the knowledge of the effects of state-mandated assessments on students with special needs. The results of this study may be published in reports for educational or policy purposes.

Your participation is voluntary and you may choose not to participate in this research student or withdraw your consent at any time or chose not to answer all questions. You will not be penalized in any way should you choose not to participate or withdraw.

All responses will remain confidential. All identifying information will not be used in this dissertation nor will reference be made to any individual that may identify such person. Pseudonyms will be used where appropriate. We will do everything we can to protect your privacy. As part of this effort, your identify will not be revealed in any publication or presentation that may result from this study and the information will remain in the possession of the investigator in a safe location.

If you have any questions regarding your rights as a human research participant, please call Missouri University Campus IRB at (573)882-9585. If you have any 
questions regarding the review and procedures of this study, you may contact Dr. Cynthia MacGregor at (417)836-6046 or cmacgregor@missouristate.edu. If you have any questions regarding your participation in this study, you may contact Teresa Nash at (417)683-5747 or tnash@avabears.net.

I have read this consent form and have been given the opportunity to ask questions. I may retain a copy of this consent form for my records. I consent to my participation in the research described above by completing the survey.

Signature of participant

Date

If the participant is under the age of 18 , parent permission is required.

Signature of Parent/Guardian

Date

Thank you for time and consideration in participating in this study.

Sincerely,

Teresa D. Nash

Principal

Ava High School 


\section{Appendix E}

\section{Survey Proctor Confidentiality/Protocol/Privacy Agreement}

The student survey is a secure test instrument. Any disclosure of test items to any person will undermine the value of the test and adversely affect the validity of test results. The confidentiality of test questions and answers is paramount in maintaining the integrity and validity of the test. The survey proctor must take every step to assure the security of these test instruments. I hereby agree that I will not disclose to any person, any materials (such as, but not limited to test design, content limits, and item specifications)

\section{Confidentiality and Protocols}

I acknowledge that I will have access to secure surveys. I also acknowledge that I have read, understand, and agree to adhere to the survey protocols. I understand that these testing materials are secure and it is my responsibility to protect their security. I therefore pledge:

1. I will not keep, copy, reproduce, paraphrase, distribute, and discuss test materials and or test items.

2. I will not use test items or information to review/prepare students for the survey.

3. I will not allow access to the test materials to any student or any other person not so authorized.

4. I will not alter students' responses in any manner.

5. I may rephrase the survey item if the student needs clarification; however, I will not change the meaning of the survey item.

6. I may survey individually or within small groups.

7. I will make sure that consent forms are on file for the student participants, along with a parent signature if the student is under 18 prior to administering the survey.

8. I will adhere to testing accommodations for each student listed in their IEP.

\section{Privacy}

To protect the privacy of students, their survey results, and performance summaries, proctors are required to agree to each statement below. Please acknowledge your agreement by reading each statement and signing below.

1. I will respect and safeguard the privacy of students and the confidentiality of the student data.

2. I will not disclose or transit confidential data to persons not specifically authorized to access these data.

\section{Signature}

Name (please print)

Does One Test Fit All? The Effects of State-Mandated Assessments on Students With Special Needs

\section{Date}

Title

Survey Title 


\section{Appendix F \\ STUDENT ASSENT FORM \\ (CHILD 15-18)}

Study Title: Does One Test Fit All? The Effects of State-Mandated Assessments on Students With Special Needs

Principal Investigator: Teresa Nash

$3^{\text {rd }}$ Party Proctor: Mr. Jeff Martin

Hello! My name is Mr. Martin and I am proctoring an on-line survey for Mrs. Nash. Mrs. Nash is a doctoral student in the Educational Leadership and Policy Analysis program at the University of Missouri - Columbia. She is conducting a research project for her dissertation. This form will give you the information you will need to understand why this study is being done and why you are being invited to participate. It will also describe what you will need to do to participate as well as any known risks, inconveniences or discomforts that you may have while participating.

I encourage you to ask questions at any time and to talk to your parents about participating. If you decide to participate, you will be asked to sign this form and it will be a record of your agreement to participate. You will be given a copy of this form to keep.

\section{PURPOSE AND BACKGROUND}

As you know, students with disabilities are required to take all state assessments. As part of Mrs. Nash's dissertation, she would like to survey students to find out what they think about taking these assessments.

\section{PROCEDURES}

This study will include an on-line survey. This study will not require you to do anything above and beyond what you would be doing in class anyway. Mrs. Nash would like to know how you feel about these assessments. If you choose not to participate, you will not be required to take the survey.

\section{RISKS/DISCOMFORTS}

This survey is confidential and there are no right or wrong answers. This is your opinion. There are no risks involved. You may ask to stop your participation at any time.

\section{EXTENT OF CONFIDENTIALITY}

The ORC monitors research studies to protect the rights and welfare of research participants.

Your name will not be used in any written reports or publications that result from this research, unless you have given explicit permission for us to do this. Data will be kept 
for three years (per federal regulations) after the study is complete and then destroyed.

\section{BENEFITS}

There will be no direct benefit to you from participating in this study. However, the information gained from this research may help education professionals better understand how state-mandated assessments affects students with special needs.

\section{PAYMENT}

There will be no payment to you as a result of taking part in this study.

\section{$>$ QUESTIONS}

If you have any questions or concerns about participation in this study, you should first talk with the investigator Teresa Nash or her advisor Dr. Cynthia MacGregor at 417-8366046. If you have questions about your rights as a research participant, you may contact the MU Institutional Review Board (IRB), which is concerned with the protection of volunteers in research projects. You may reach the board office by calling (573) 8823181 or by writing: MU Institutional Review Board, Office of Research, University of Missouri, 482 McReynolds Hall, Columbia, MO 65212.

\section{DOCUMENTATION OF CONSENT}

I have read this form and decided that I will participate in the project described above. Its general purposes, the particulars of involvement and possible risks have been explained to my satisfaction. I understand I can withdraw at any time. I have received a copy of this form.

I understand that I can choose not to participate in this study, or to withdraw from participating at any time. Declining participation will not interfere with my learning experiences in my classroom. I understand that by not participating in this study, I will be provided with the same activities and experiences as all other pre-calculus students.

Printed Name of Study

Participant

Signature of Study $\quad$ Date
Participant

Participant
Date 


\section{Appendix G}

\section{Recruitment Scripts}

To the Superintendent (in person):

"Hello, I am Teresa Nash. I am a student at the University of Missouri-Columbia. I am researching the effects that state-mandated assessments have on students with special needs. I am asking your permission to give an on-line survey to students with special needs, facilitate a focus group discussion with special education teachers, and interview the special education director. I am anticipating the survey to take about 15 minutes to complete. The focus group discussion and interview will take about 30 minutes to complete. I will be collecting Informed Consent for Participants from parents, special education teachers, and the special education director as well as Child Assent Forms by student participants prior to data collection.

May I perform this study within your district?

(Wait for response)

If you have any questions, you may contact me at (417) 683-5747 or tnash@avabears.net. Thank you for your help."

If not interested, the researcher will end the conversation: "Thank you for your time."

To Parents (on the phone):

"Hello, my name is Jeff Martin. I am proctoring a research study for Mrs. Nash about student perceptions regarding state-mandated assessments. Mrs. Nash is a student at the University of Missouri-Columbia. I am calling to ask if you would be willing to let your child participate in an on-line survey about the effects of state-mandated assessments for students with special needs. The survey will only take about 15 minutes to complete.

If you are interested in your child participating in this survey, I will send home a parent consent form for both parents to sign.

(Give parents an opportunity to respond. Send home Informed Consent for Participation in Research Activities form.)

I will be sending home an Informed Consent for Participation in Research Activities form for both parents to sign. If you have any questions, you can reach Mrs. Nash at 417-6835747 or tnash@avabears.net. Thank you for your help."

If not interested, the proctor will end the call: "Thank you for your time." 
To Students (in person):

"Hello, my name is Jeff Martin. I am proctoring a research study for Mrs. Nash about student perceptions regarding state-mandated assessments. Mrs. Nash is a student at the University of Missouri-Columbia. I am asking if you would participate in an on-line survey about the effects of state-mandated assessments for students with special needs. The survey will only take about 15 minutes to complete.

If you are interested, I have a consent form for you to sign.

(Give students an opportunity to respond. They will have 48-72 hours to respond if they are unsure.)

If you have any questions, you can reach Mrs. Nash at 417-683-5747 or tnash@avabears.net. Thank you for your help.”

If not interested, the proctor will end the conversation: "Thank you for your time."

To Special Education Teachers/Special Education Director (in person):

"Hello, I am Teresa Nash. I am a student at the University of Missouri-Columbia. I am researching the effects that state-mandated assessments have on students with special needs. The focus group discussion/interview will take about 30 minutes to complete.

If you are interested, I have a consent form for you to sign.

(Give teachers/special education director an opportunity to respond. They will have 4872 hours to respond if they are unsure.)

If you have any questions, you can ask now or reach me at 417-683-5747 or tnash@avabears.net. Thank you for your help."

If not interested, the proctor will end the conversation: "Thank you for your time." 
Appendix $\mathrm{H}$

\section{UNIVERSITY OF MISSOURI -- COLUMBIA PARENTAL PERMISSION FORM FOR CHILD'S RESEARCH PARTICIPATION}

IRB Number:

Title of Study:

Principal Investigator:

Third Party Proctor:
221467

Does One Test Fit All? The Effects of State-Mandated Assessments on Students With Special Needs

Teresa D. Nash

Jeff Martin

Your child is being asked to take part in a research study. This form has important information about the reason for doing this study, what we will ask your child to do, and the way we would like to use information about your child if you choose to allow your child to be in the study.

\section{Why are you doing this study?}

Your child is being asked to participate in a research study about the effects of state-mandated assessments on students with special needs.

The purpose of this study will be to analyze the perceptions of students with special needs, and educators of students with special needs regarding the requirement that all students who do not qualify for an alternative assessment take the same assessment at the same grade level, regardless of current level of performance. Students with various needs who are currently not performing a grade level must take the same assessment as their same-aged peers. The focus of this study will be on the perceptions of students and teachers, and how the continuous basic and below basic achievement levels have effected students' self-esteem and outlook for future goals.

\section{What will my child be asked to do if my child is in this study?}

Your child will be asked to complete a short on-line survey about their perceptions on statemandated assessments and how these assessments make them feel. Participation should take about 20-30 minutes.

\section{What are the possible risks or discomforts to my child?}

Your child's participation in this study does not involve any physical or emotional risk to your child beyond that of everyday life.

As with all research, there is a chance that confidentiality of the information we collect about your child could be breached - we will take steps to minimize this risk, as discussed in more detail below in this form.

What are the possible benefits for my child or others?

Taking part in this research study may not benefit your child personally, but we may learn new things that will help others.

How will you protect the information you collect about my child, and how will that information be shared? 
Results of this study may be used in publications and presentations inform policy makers and educators about how state mandated assessments affect students with special needs. The findings of this study may be published in national journals; however, no identifiable information will be shared. Data collected will be stored electronically under password protection.

Financial Information -- Participation in this study will involve no cost to you or your child. Your child will not be paid for participating in this study.

\section{What are my child's rights as a research participant?}

Participation in this study is voluntary. Your child may withdraw from this study at any time -you and your child will not be penalized in any way or lose any sort of benefits for deciding to stop participation. If you and your child decide not to be in this study, this will not affect the relationship you and your child have with your child's school in any way. Your child's grades will not be affected if you choose not to let your child be in this study.

If your child decides to withdraw from this study, the researchers will ask if the information already collected from your child can be used.

\section{Who can I contact if I have questions or concerns about this research study?}

If you or your child has any questions, you may contact the primary researcher at: Teresa Nash, (417) 683-5747, tnash@avabears.net.

If you have any questions about your child's rights as a participant in this research, you can contact the following office at the University of Missouri-- Columbia:

MU Institutional Review Boards

Office of Research

University of Missouri

Columbia, MO 65212

Phone: $573-882-3181$

\section{Parental Permission for Child's Participation in Research}

I have read this form and the research study has been explained to me. I have been given the opportunity to ask questions and my questions have been answered. If I have additional questions, I have been told whom to contact. I give permission for my child to participate in the research study described above and will receive a copy of this Parental Permission form after I sign it.

Initial one of the following to indicate your choice: (Initial) I agree to... (Initial) I do not agree to... 


\section{A. Consent to Quote from Interview}

I may wish to quote from the interview with your child either in the presentations or articles resulting from this work. A pseudonym (fake name) will be used in order to protect your child's identity.]

Parent/Legal Guardian's Name (printed) and Signature

Date

Name of Person Obtaining Parental Permission

Date

Parents, please be aware that under the Protection of Pupils Rights Act (20 U.S.C. Section 1232 (c)(1)(A)), you have the right to review a copy of the questions asked of or materials that will be used with students. If you would like to do so, you should contact Teresa Nash to obtain a copy of the questions or materials. 


\section{VITA}

Teresa Dawn Nash was born in the Ava, Missouri area on January 8, 1967. She attended grades K-12 in the Ava R-1 School District and graduated in 1985. She received her Bachelors of Arts in Cross-Categorical Special Education K-12 from Missouri State University in 2000. After teaching Special Education for five years at Ava High School, she decided to pursue a career in educational administration and is currently in her fourteenth year as an administrator at Ava High School in Ava, Missouri. She received her Master’s Degree in Educational Administration K-12 in 2004 and completed her Specialist’s Degree in Educational Administration Superintendency in 2012. In July 2017, she completed her Doctorate Degree in Educational Leadership and Policy Analysis from University of Missouri in Columbia, Missouri. 